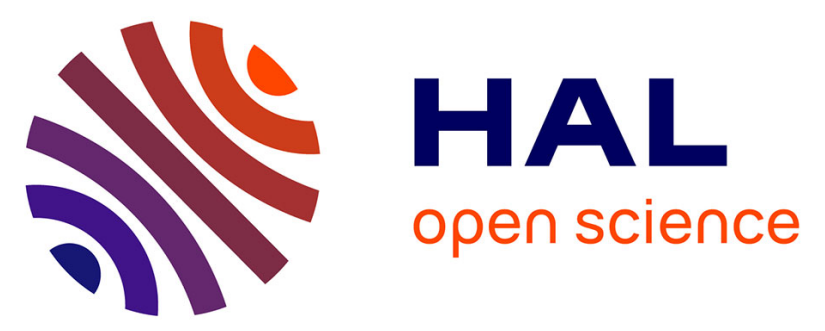

\title{
From Synthetic Simplified Marine Metabolite Analogues to New Selective Allosteric Inhibitor of Aurora B Kinase
}

Charlotte Juillet, Ludmila Ermolenko, Dina Boyarskaya, Blandine Baratte, Beátrice Josselin, Hristo Nedev, Stéphane Bach, Bogdan Iorga, Jérôme Bignon, Sandrine Ruchaud, et al.

\section{To cite this version:}

Charlotte Juillet, Ludmila Ermolenko, Dina Boyarskaya, Blandine Baratte, Beátrice Josselin, et al.. From Synthetic Simplified Marine Metabolite Analogues to New Selective Allosteric Inhibitor of Aurora B Kinase. Journal of Medicinal Chemistry, 2021, 64 (2), pp.1197-1219. 10.1021/acs.jmedchem.0c02064 . hal-03154739

\author{
HAL Id: hal-03154739 \\ https://hal.science/hal-03154739
}

Submitted on 8 Mar 2021

HAL is a multi-disciplinary open access archive for the deposit and dissemination of scientific research documents, whether they are published or not. The documents may come from teaching and research institutions in France or abroad, or from public or private research centers.
L'archive ouverte pluridisciplinaire $\mathbf{H A L}$, est destinée au dépôt et à la diffusion de documents scientifiques de niveau recherche, publiés ou non, émanant des établissements d'enseignement et de recherche français ou étrangers, des laboratoires publics ou privés. 


\section{From Synthetic Simplified Marine Metabolite Analogs to New Selective Allosteric Inhibitor of Aurora B Kinase}

Charlotte Juillet, ${ }^{\dagger}$ Ludmila Ermolenko, ${ }^{\dagger}$ Dina Boyarskaya, ${ }^{\dagger}$ Blandine Baratte,${ }^{\ddagger}$ Béatrice Josselin, ${ }^{\ddagger}$ Hristo

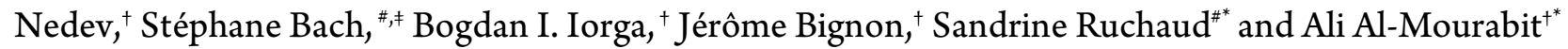

†Université Paris-Saclay, CNRS, Institut de Chimie des Substances Naturelles, Gif-sur-Yvette, 91190, France

"Sorbonne Université, CNRS, FR 2424, Plateforme de criblage KISSf, Station Biologique de Roscoff, Roscoff, 29680, France

"Sorbonne Université, CNRS, UMR 8227, Integrative Biology of Marine Models Laboratory (LBI2M), Station Biologique de Roscoff, Roscoff, 29680, France

KEYWORDS: kinase, allosteric inhibitor, allosteric inhibitor, Aurora B, pyrrole-imidazole, mitosis, cancer

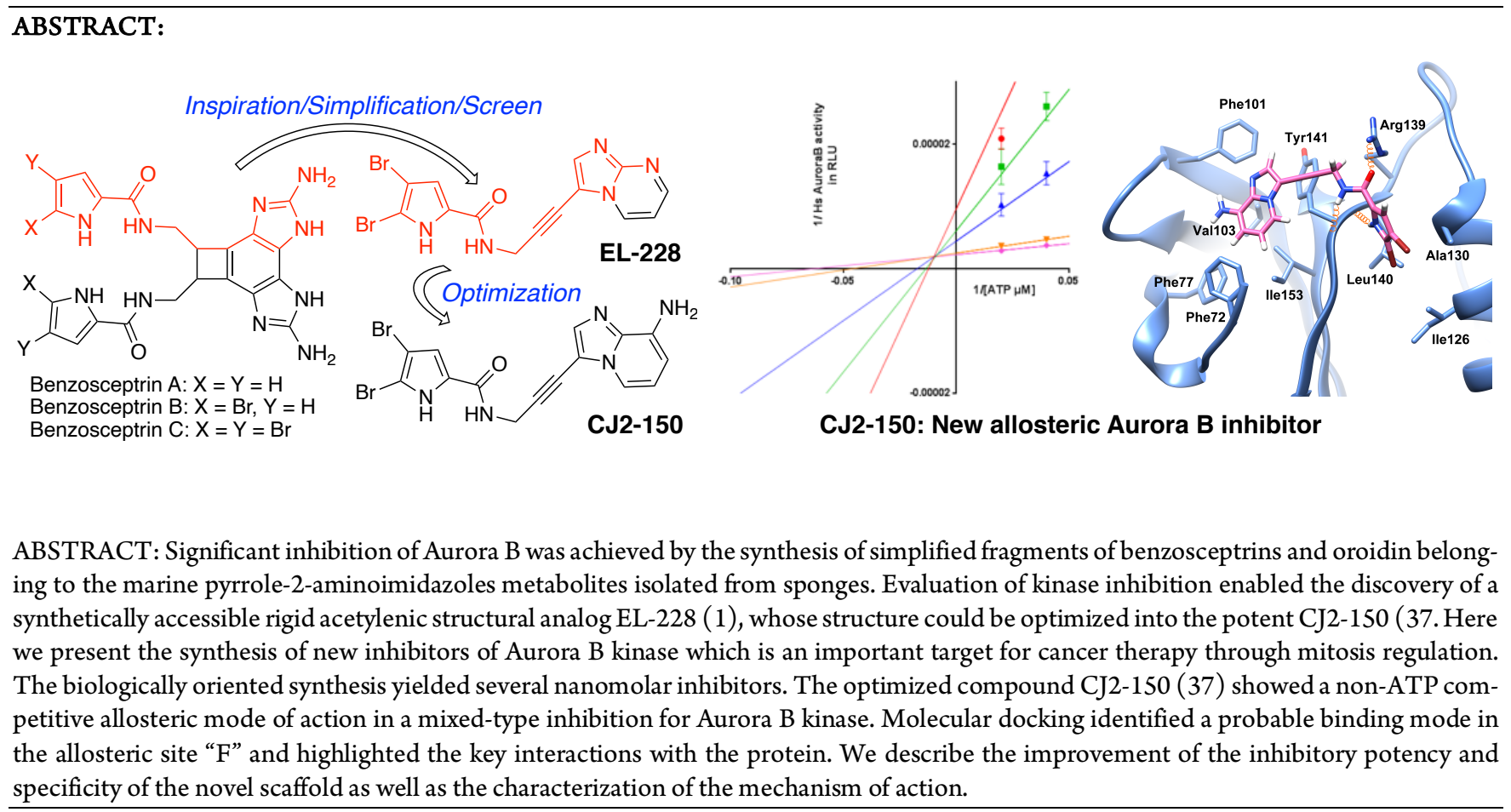




\section{- INTRODUCTION}

Aurora kinases A, B and C are serine-threonine protein kinases, expressed in cells during mitosis that play an essential role via mitosis regulation. ${ }^{1}$ Aurora $\mathrm{B}$ is a member of the chromosomal passenger complex (CPC) together with INCENP, Borealin and Survivin. It is localized at the centromere in early mitosis, and then during the anaphase, Aurora B relocates to the microtubules at the central spindle. ${ }^{2,3}$ Aurora B seems to be involved in chromatin compaction and condensation via the phosphorylation of histone $\mathrm{H}_{3}$ at serine 10. ${ }^{4,5}$ It promotes the proper chromosomes alignment and segregation. Aurora B is a key component of the error correction machinery and is responsible for the selective destabilization of incorrect attachments between microtubules and kinetochores. ${ }^{6,7}$

Aurora B inhibition results in a weakened spindle-checkpoint ${ }^{7}$ with chromosomes prone to mis-segregation and cytokinesis failure. As Aurora $\mathrm{B}$ is involved in the cleavage furrow ingression and abscission, ${ }^{8,9,10}$ its inhibition creates polyploidization and drags the cell into aberrant mitosis leading to its death by apoptosis. Aurora kinases are up-regulated in various tumor cells and are responsible for genomic instability associated with tumorigenesis. ${ }^{11,12,13}$ Their overexpression is highly correlated with poor diagnosis of cancers.

As Aurora kinases are all implicated during cell division at different stages, this family of kinases has sparked great interest over the last two decades as new targets in cancer therapy. ${ }^{14} \mathrm{~A}$ few representatives Aurora B inhibitors are shown in Figure 1. To date no smallmolecule inhibitor of Aurora B has been approved by the FDA; nevertheless, numerous compounds are described in the literature $^{15,16}$ or undergoing clinical trials at different stages. ${ }^{17,18,19}$ So far, all of these are ATP-competitive though this mode of binding might suffer from off-target effects due to the high degree of conservation among kinases, leading to a potential lack of specificity.
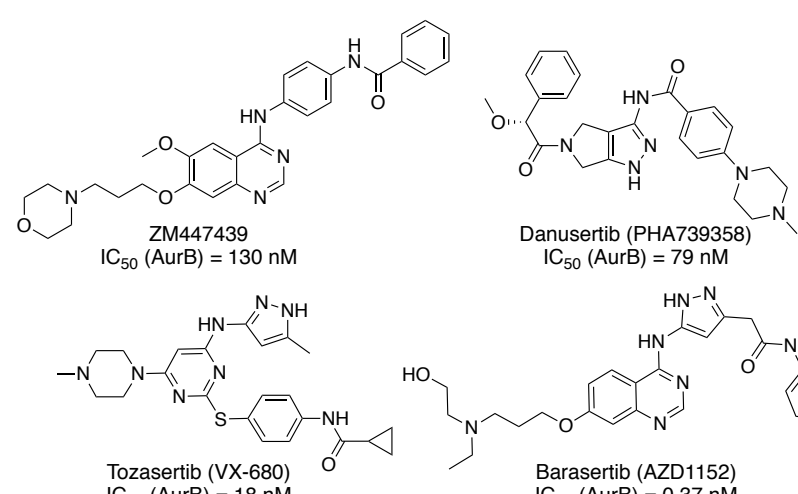

$I_{50}($ AurB $)=18 \mathrm{nM}$

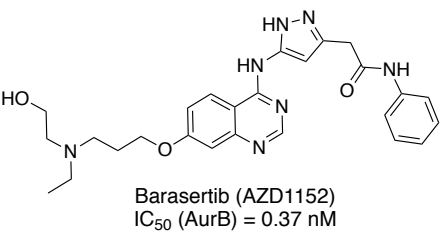

Figure 1: Examples of known ATP-competitive Aurora B inhibitors.

Consequently, instead of designing molecules targeting the ATP binding pocket for competitive inhibition, we decided to explore a different chemical space as a possible route to novel inhibitory mechanisms. For this purpose, simplification of the complex structures of bioactive natural products is often advantageous and even necessary for their valorization in drug discovery. ${ }^{20}$ In this context, we considered synthetic fragments inspired by the rigid benzosceptrins $A, B$ and $C^{21,22,23}$ isolated by our group (Figure 2 ). The idea for the design of new inhibitors was to extract privileged active structural motifs of the marine benzosceptrins and oroidin and further optimize their activity. ${ }^{24,25,26}$

In the present study, we describe pharmacomodulation of the hit EL-228 (1) (Figure 2), leading to the identification of a new active class of compounds similar to the oroidin scaffold, the monomer of dimeric benzosceptrin metabolite. Importantly, we have shown that these compounds are non-ATP competitive inhibitors. To the best of our knowledge, this is the first example of such a binding mode for Aurora B inhibitors (Figure 2).
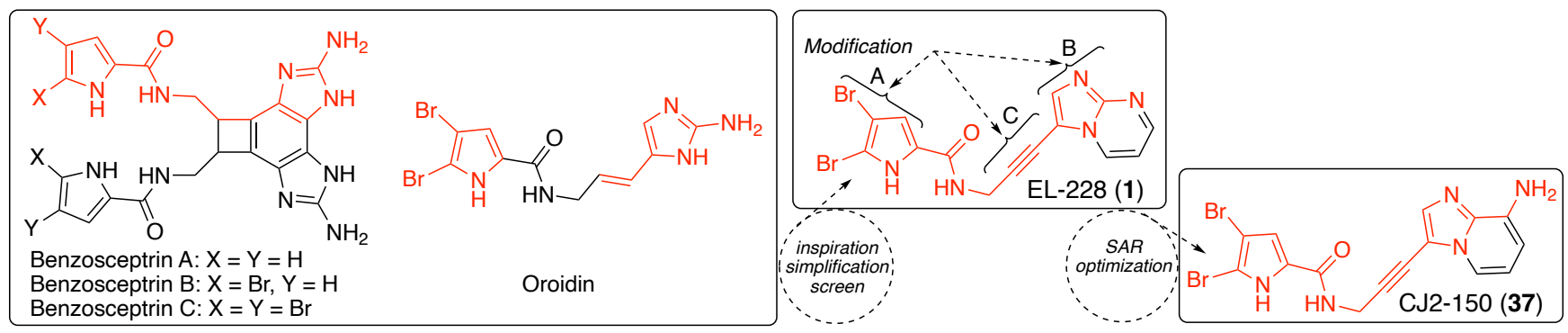

Figure 2: Fragment reasoning containing the pyrrole and the 2-aminoimidzole of the marine benzosceptrins

In addition to the micromolar inhibition of the CK1 kinase by the natural product benzosceptrin $\mathrm{B}\left(\mathrm{IC}_{50}=0.68 \mu \mathrm{M}\right)$, the pyrrole-2aminoimidazole metabolites are known to have affinity for other kinases. As part of the total synthesis of benzosceptrins A-C, various simplified intermediates were prepared and screened on a panel of kinases. From this screening, a moderately potent but relatively selective inhibitor of Aurora B kinase, EL-228 (1) $\left(\mathrm{IC}_{50}=5\right.$ $\mu \mathrm{M}$ ), was highlighted (Figure 2). The structure, linking a dibromopyrrole with an imidazo[1,2-a]pyrimidine heterocycle via an alkyne offered the possibility of exploring a new chemical space. These initial three structural elements A, B and C (Figure 2) were then modified consecutively in order to improve activity and explore structure-activity relationships. Among the new analogs synthesized, the most active was shown to be compound CJ2-150
(37). A study of the latter's mode of action then revealed it to be a non-ATP competitive inhibitor of Aurora B kinase, the first of its kind.

\section{- RESULTS AND DISCUSSION}

Chemistry. Modifications of the pyrrole moiety part A. Our synthetic strategy began with the synthesis of the Boc propargylamine 5 from $4^{27}$ and the iodoimidazopyrimidine 3 from 2-AP $2 a^{28}$ Sonogashira coupling of the aryl halide 3 with the alkyne 5 led to the platform 6 that was deprotected to the trifluoroacetic acid salt 7.29 The last step was an EDCI-mediated acylation with various carboxylic acids to give four analogs $\mathbf{8 a - d}$ (Scheme 1). The pyrrole part was replaced by the dibrominated five-membered rings furan and thiophen to produce $11 \mathbf{a}-\mathbf{b}$ from 
the corresponding carboxylic acids $9 a$ and $9 \mathbf{b}$ through the acetylenic derivatives $10 \mathrm{a}$ and $10 \mathrm{~b}$. Finally, another efficient synthetic route allowed us to synthesize the pyrrole bearing two methyl groups instead of the bromines. The key pyrrole 12 was prepared according to the literature from ethylacetoacetate, ethyl formate and 2-butanone respectively (see Supporting Information). ${ }^{30,31,32}$ After hydrolysis of the ester 12 to $9 c$, a Sonogashira cross-coupling with propargylamine and $10 \mathrm{c}$ gave the compound $11 \mathrm{c}$.

Scheme 1. General synthesis of the analogs with modified pyrrole part A
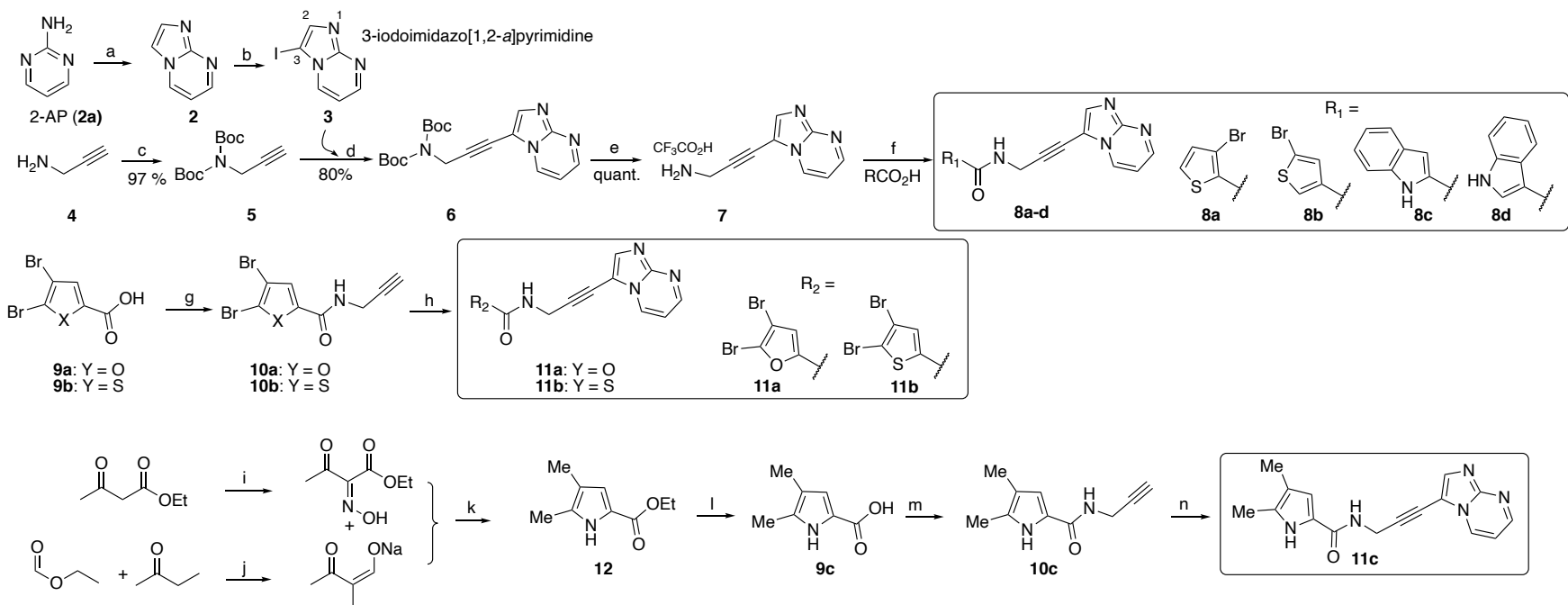

Reagents and conditions: (a) Chloroacetaldehyde, EtOH reflux, quant.; (b) NIS, ACN, 32\%; (c) Boc 2 O, DMAP, ACN, rt, 16 h, $97 \%$; (d) $\mathrm{Pd}\left(\mathrm{PPh}_{3}\right)_{2} \mathrm{Cl}_{2}$ 10\%, CuI 10\%, NEt 3 , 81\%; (e) TFA, DCM, 80\%; (f), EDC.HCl, HOBT, DIEA, rt, DCM, 17-56\%; (g) Propargylamine, T 3 , DIEA, EtOAc; (h) 3, $\mathrm{Pd}\left(\mathrm{PPh}_{3}\right)_{2} \mathrm{Cl}_{2}$, CuI, Et 3 N, DMF, $50{ }^{\circ} \mathrm{C}$, 40-48\% ; (i) $\mathrm{NaNO}_{2}, \mathrm{AcOH}_{2} \mathrm{H}_{2} \mathrm{O}, 81 \%$; (j) $\mathrm{NaOMe} 5.4 \mathrm{M}$ in $\mathrm{MeOH}, \mathrm{THF}$ dry, 60\%; (k) $\mathrm{Zn}, \mathrm{AcOH}$, dioxane $/ \mathrm{H}_{2} \mathrm{O}, 80^{\circ} \mathrm{C}$, 66\%; (l) $\mathrm{LiOH} . \mathrm{H}_{2} \mathrm{O}, \mathrm{MeOH} / \mathrm{H}_{2} \mathrm{O}, 70^{\circ} \mathrm{C}, 76 \%$; (m) Propargylamine, $\mathrm{T}_{3} \mathrm{P}$, DIEA, EtOAc, 69\%; (n) 3, $\mathrm{Pd}\left(\mathrm{PPh}_{3}\right)_{2} \mathrm{Cl}_{2}, \mathrm{CuI}, \mathrm{Et}_{3} \mathrm{~N}, \mathrm{DMF}, 50^{\circ} \mathrm{C}, 52 \%$.

To explore the effect of the nature and the degree of pyrrole substitutions with halogens on the biological activity, several chlorinated, brominated or iodinated pyrrole derivatives were prepared from trichloroacetylpyrrole (13) ${ }^{33,34,35}$ Amidation of 14a-14d with commercial propargylamine followed by Sonogashira coupling of the resulting acetylenes with the previously prepared iodoimidazopyrimidine 3 provided compounds $\mathbf{1}$ and $\mathbf{1 6 b}$-e in yields varying from $20 \%$ to $86 \%$ (Scheme 2). ${ }^{36,37,38}$

Scheme 2. Variation of the nature and degree of pyrrole substitutions by halogens

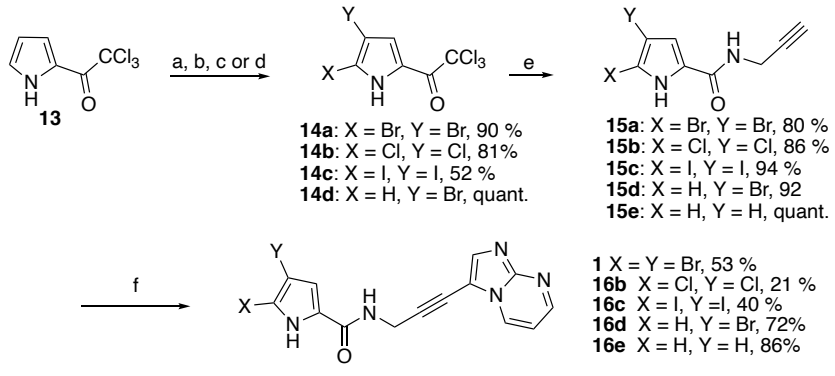

Reagents and conditions: (a) $\mathrm{Br}_{2}, \mathrm{AcOH}$; (b) $\mathrm{I}_{2}, \operatorname{AgTFA}, \mathrm{CHCl}_{3}$; (c) $\mathrm{SO}_{2} \mathrm{Cl}_{2}, \mathrm{CHCl}_{3}$; (d) $\mathrm{Br}_{2} 1$ equiv., $\mathrm{AcOH}$; (e) propargylamine, $60^{\circ} \mathrm{C}$; (f) 3, $\mathrm{Pd}\left(\mathrm{PPh}_{3}\right)_{2} \mathrm{Cl}_{2}, \mathrm{CuI}, \mathrm{Et}_{3} \mathrm{~N}, \mathrm{DMF}, 60^{\circ} \mathrm{C}$.

Modifications of the bicyclic moiety part B. Nitrogen positions within the bicyclic ring and substituent effects were examined. The precursor aromatic halides $19 \mathbf{a}-\mathbf{c}$ were synthesized based on previous literature methods. Thus, cyclization of $17 \mathbf{a}-\mathbf{c}$ followed by iodination using the two-step method as for 3 provided $19 \mathrm{a}-\mathrm{c}$ (Scheme 1), 39, 40, 41, 42 while compounds $19 \mathrm{~d}$-j were commercially available. Sonogashira coupling of $19 a-j$ with the alkyne $15 a$ then afforded compounds $20 \mathrm{a}-\mathrm{j}$ regioselectively though in rather low yields varying from $10 \%$ to $36 \%$. In addition, Sonogashira coupling of $19 \mathrm{a}$ with the alkynes $15 \mathrm{~b}$ and $\mathbf{1 5 c}$ gave the dichloro and diiodo derivatives 20k-1 respectively. The same reaction between the bicycle $19 c$ and the acetylenic $15 b$ and $15 c$ gave the dichloro and diiodo derivatives $20 \mathrm{~m}-\mathbf{n}$ respectively (see Supporting Information).

Scheme 3. Variation of the east bicycle

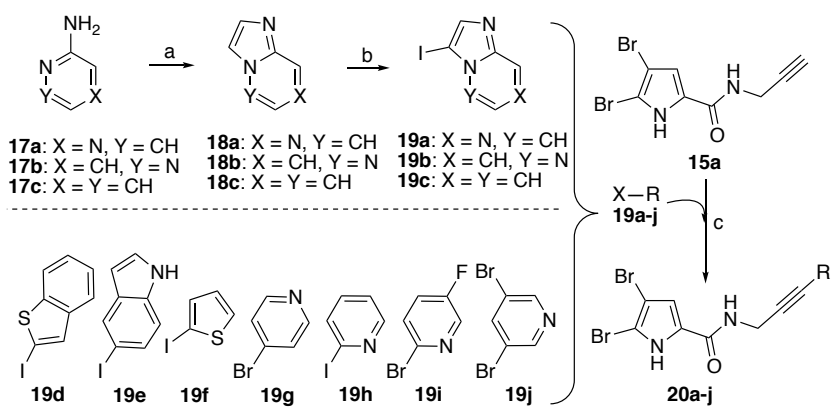


Reagents and conditions: (a) Chloroacetaldehyde, EtOH or ACN $70^{\circ} \mathrm{C}, 100 \%$; (b) NIS, ACN 64-100\% (19b and $19 \mathrm{c}$ ) or $\mathrm{I}_{2}$, pyridine, $42 \%(19 \mathrm{a}) ;(\mathrm{c}) \mathrm{Pd}\left(\mathrm{PPh}_{3}\right)_{2} \mathrm{Cl}_{2} 5 \%, \mathrm{CuI} 10 \%, \mathrm{Et}_{3} \mathrm{~N}, \mathrm{THF}, 50^{\circ} \mathrm{C}, 10-$ $46 \%$

Since the most active compound was the imidazopyridine 20c, we decided to add various substituents to the imidazopyridine moiety in order to evaluate which positions most affect activity. This was achieved from the corresponding commercially available substituted amino pyridines $21 \mathrm{a}-\mathrm{h}$ which were subjected to the previous cyclization-iodination sequence to provide $23 \mathbf{a}-\mathbf{h}^{43,44,45,46,47,48,49}$ followed by Sonogashira cross-coupling to afford compounds $24 \mathrm{a}-\mathbf{h}$ (Scheme 4, see Supplementary data for full details).

Scheme 4. Imidazopyridine substitutions

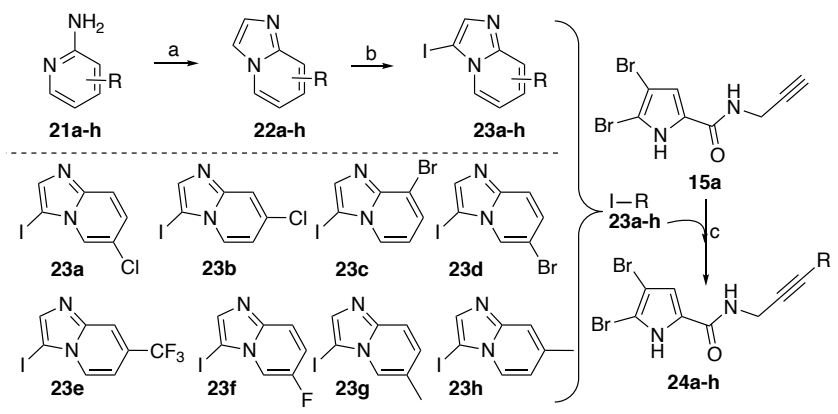

Reagents and conditions: (a) Chloracetaldehyde, EtOH, reflux; 79-100 \%; (b) NIS, ACN, 65-97\%; (c) R-I, $\mathrm{Pd}\left(\mathrm{PPh}_{3}\right)_{2} \mathrm{Cl}_{2}, \mathrm{CuI}$, $\mathrm{Et}_{3} \mathrm{~N}, \mathrm{THF}, 5-63 \%$.
Compound 29 (Scheme 5), bearing a 7-azaindole ring system was prepared by a sequence of transformations including iodination of the commercially available 7 -azaindole with $N$-iodosuccinimide, protection with benzenesulfonyl chloride, Sonogashira reaction with the alkene 15a, and finally deprotection with TBAF in THF. ${ }^{50}$

Scheme 5. 7-aza-indole derivative preparation

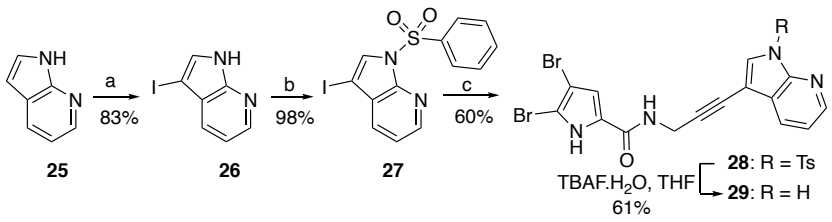

Reagents and conditions: (a) $\mathrm{I}_{2}, \mathrm{KI}, \mathrm{NaOH} 1 \mathrm{~N}, \mathrm{EtOH}, 83 \%$ (b) $\mathrm{PhSO}_{2} \mathrm{Cl}, \mathrm{Bu}_{4} \mathrm{NBr}, \mathrm{NaOH}, \mathrm{DCM}$ dry, $98 \%$; (c) 15a, $\mathrm{Pd}\left(\mathrm{PPh}_{3}\right)_{2} \mathrm{Cl}_{2}$, CuI, $\mathrm{Et}_{3} \mathrm{~N}$, THF, 60\% ; (d) TBAF. $\mathrm{H}_{2} \mathrm{O}$, THF, $61 \%$.

To explore the effect of an exocyclic amine on the bicyclic portion of the framework, different aromatic amines were introduced at positions 6 and 8 (Scheme 6). After preparation of $\mathbf{3 1 a},{ }^{51,52} \mathbf{3 1} \mathbf{b}$ and 31c, ${ }^{53,54} \mathrm{~N}$-protection of the amino-imidazopyridine with acetyl chloride or $\mathrm{Boc}_{2} \mathrm{O}$ when necessary and subsequent iodination, followed by Sonogashira coupling allowed the synthesis of compounds $35,36,37,38$ and 43 . The deprotection of the amines of 36 and other di-Boc intermediaites was achieved with TFA in DCM producing into $\mathbf{3 7 ,} 38$ and 43 (Scheme 6). ${ }^{55}$ In addition, Sonogashira coupling of $\mathbf{3 3 b}$ with $\mathbf{1 5 b}$ (dichloro) and $\mathbf{1 5 c}$ (diiodo) gave after deprotection the dichloro and diiodo derivatives $\mathbf{4 4}$ and $\mathbf{4 5}$ (see SI).

Scheme 6. Introduction of an exocyclic aromatic primary amine on positions 6 and 8

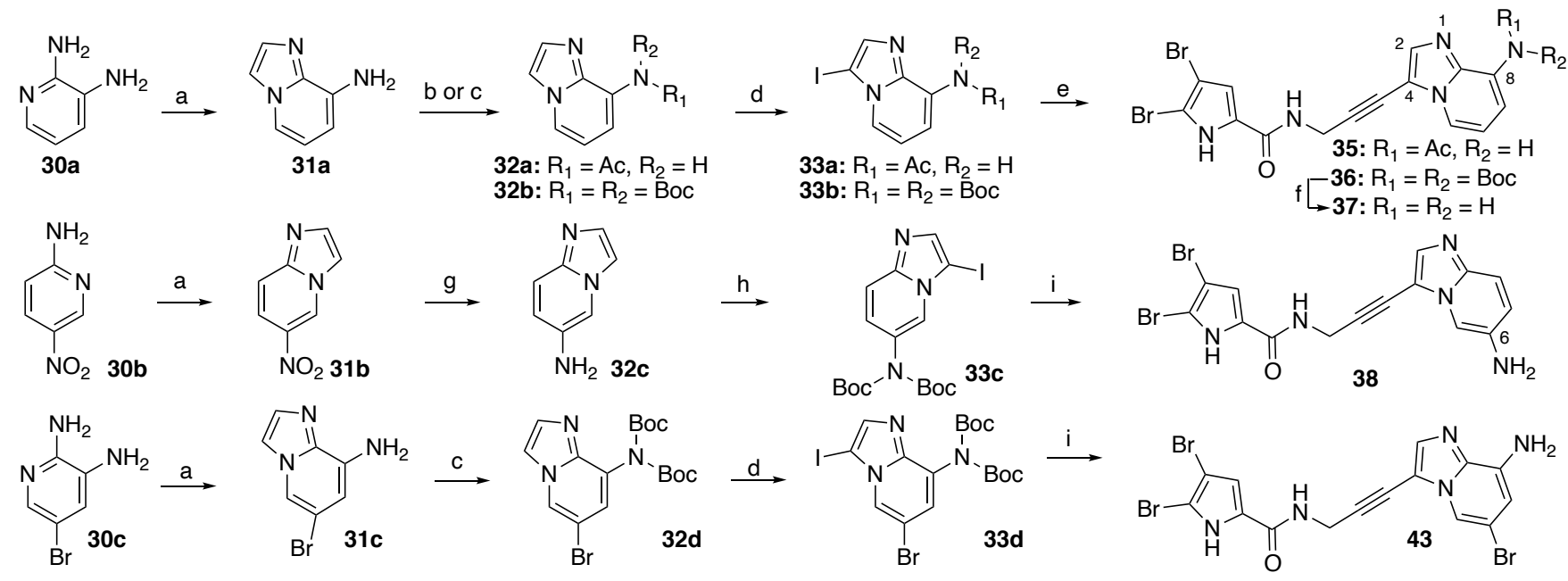

Reagents and conditions: (a) Chloroacetaldehyde, EtOH reflux, 65-93\%; (b) Ac 2 O, DCM, 95\%; (c) Boc 2 O, DCM, DMAP, 39-67\%; (d) NIS, ACN, 88 - $100 \%$; (e) 15a, $\mathrm{Pd}\left(\mathrm{PPh}_{3}\right)_{2} \mathrm{Cl}_{2}$ 5\%, CuI 10\%, Et 3 N, THF, 35-66\%; (f) TFA, DCM, 70\%; (g) $\mathrm{SnCl}_{2} .2 \mathrm{H}_{2} \mathrm{O}, \mathrm{HCl}, \mathrm{EtOH}, 78 \%$; (h) $\mathrm{Boc}_{2} \mathrm{O}, \mathrm{Et}_{3} \mathrm{~N}, \mathrm{DMF}$ and NIS, ACN, 38\%; (i) $15 \mathrm{a} \mathrm{Pd}\left(\mathrm{PPh}_{3}\right)_{2} \mathrm{Cl}_{2} 5 \%, \mathrm{CuI} 10 \%, \mathrm{Et}_{3} \mathrm{~N}$, DMF; then TFA, DCM (yields over two steps : $11 \%$ for 38 and $59 \%$ for 43 ).

The preparation of derivatives $\mathbf{4 8}$ and $\mathbf{5 0}$ having additional salifiable groups is shown in Scheme 7. The halogenated intermediates $47 a$ and $47 b$ were prepared from $46 a$ and $46 b$ using Buchwald coupling with $\mathrm{N}$-Boc-piperazine or morpholine in the presence of $\mathrm{XPhos}$ as ligand followed sequentially by iodination, Sonogashira coupling and then, in the case of 49 , piperazine $N$-Boc cleavage with $\mathrm{HCl}$ into 50. ${ }^{34,56}$

Scheme 7. Morpholine and piperazine derivatives preparation 


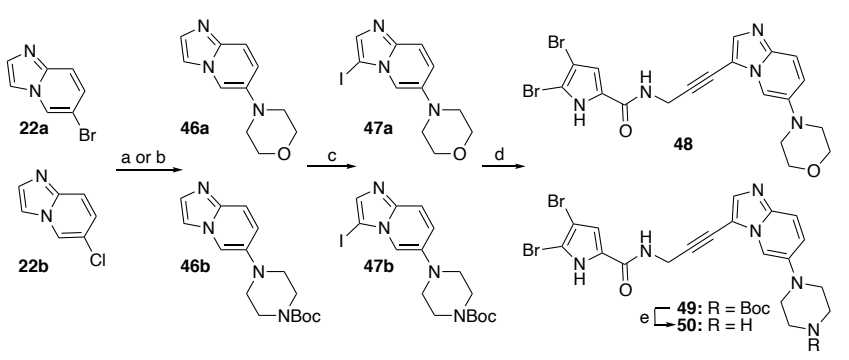

Reagents and conditions: (a) Morpholine, $\mathrm{Pd}_{2}(\mathrm{dba})_{3}$, XPhos, $\mathrm{NaOtBu}$, toluene, $100^{\circ} \mathrm{C}, 62 \%$; (b) Boc-piperazine, $\mathrm{Pd}_{2}(\mathrm{dba})_{3}$, $\mathrm{XPhos}, \mathrm{NaOtBu}$, toluene, $100^{\circ} \mathrm{C}$, quant.; (c) NIS, ACN 55-100\%; (d) $15 \mathrm{a}, \mathrm{Pd}\left(\mathrm{PPh}_{3}\right)_{2} \mathrm{Cl}_{2} 5 \mathrm{~mol} \%$, CuI $10 \mathrm{~mol} \%, \mathrm{Et}_{3} \mathrm{~N}, \mathrm{THF}, 22-61 \%$ ; (e) $\mathrm{HCl} 4 \mathrm{~N}$ dioxane, DCM, $72 \%$

Modification of the linker moiety $C$. In order to vary the flexibility of the molecules, we first replaced the acetylene linker by an alkene. The alkene series was prepared as described in Scheme 8. N-Bocprotected propargylamine $51 \mathrm{a}^{57}$ was subjected to a hydrozirconation-hydroboration sequence with pinacol borane and Schwartz's reagent to produce the key building block $\mathbf{5 1 b} .^{58,59}$ Suzuki coupling with the corresponding iodo compounds $19 \mathrm{a}-\mathrm{c}$ gave compounds 52-54. After $N$-Boc cleavage of the latter with aqueous $4 \mathrm{~N} \mathrm{HCl}$, the resulting amines were acylated using the trichloroacetyl dibromopyrrole 14a.

Scheme 8. Synthesis of derivatives with an alkene linker

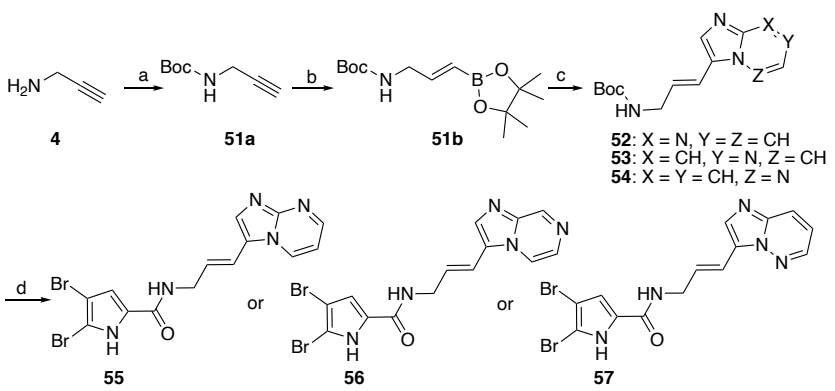

Reagents and conditions: (a) $\mathrm{Boc}_{2} \mathrm{O}, \mathrm{DMAP}, \mathrm{DCM}, 97 \%$; (b) Pinacolborane, $\mathrm{Cp}_{2} \mathrm{ZrHCl} 25 \mathrm{~mol} \%, \mathrm{Et}_{3} \mathrm{~N} 25 \mathrm{~mol} \%, 40^{\circ} \mathrm{C}, 73 \%$; (c) R-I, $\mathrm{Pd}\left(\mathrm{PPh}_{3}\right)_{4} 5 \mathrm{~mol} \%, \mathrm{~K}_{2} \mathrm{CO}_{3}(2 \mathrm{M})$, Dioxane, $80^{\circ} \mathrm{C}, 47-100 \%$; (d) $\mathrm{HCl} 4 \mathrm{~N}$ then trichloroacetyl dibromopyrrole $14 \mathrm{a}, 37 \%-51 \%$.

We next investigated aromatic linkers between our various bicyclic heterocycles and the most active dibromopyrrole structural motif. Namely, we proposed to introduce a forced orientation in a series of compounds that contain regioisomers and both meta and para benzene substitutions. Imidazopyrimidine and imidazopyridazine cores were obtained from the cyclization of the corresponding 2aminopyrimidine and 3-aminopyridazin with the nitrophenyl- $\alpha$ bromoketone $\mathbf{5 8}$ (Scheme 9). ${ }^{60,61,62}$ The nitro derivatives 59 and 60 were reduced to the corresponding aromatic amines 61 and 62 with tin (II) chloride under acidic conditions. The latter were then coupled with either trichloroacetyl dibromopyrrole $14 \mathrm{a}$ in $\mathrm{Et}_{3} \mathrm{~N}$ or with the acyl chloride prepared in situ to afford 63 and 64, respectively. ${ }^{63}$

Scheme 9. Synthesis of derivatives with a meta benzene linker at $\mathrm{C} 2$

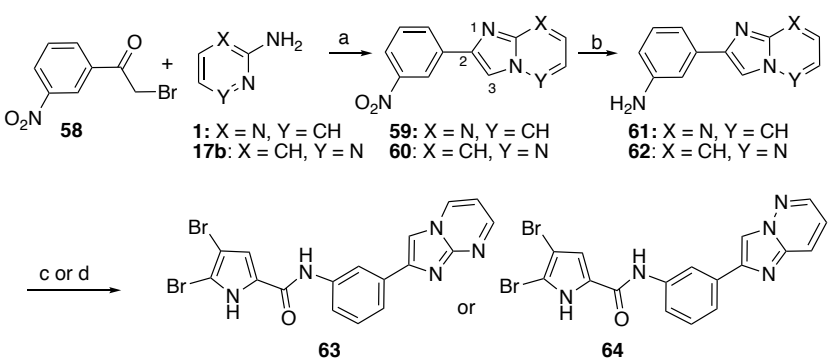

Reagents and conditions: (a) EtOH, reflux 41-71 \%; (b) $\mathrm{SnCl}_{2} .2 \mathrm{H}_{2} \mathrm{O}, \mathrm{HCl}, \mathrm{EtOH}, 62-78 \%$; (c) Trichloroacetyl dibromopyrrole 14a $\mathrm{Et}_{3} \mathrm{~N}, 60^{\circ} \mathrm{C}$, $49 \%$; (d) Dibromopyrrole carboxylic acid, $(\mathrm{COCl})_{2}$, DCM/DMF, $72 \%$.

The preparation of the new $\mathrm{C} 3$ regioisomers and benzene metalinked 67a-d or benzene para-linked 68a-d was achieved from 19ac and 3 via a Suzuki coupling, ${ }^{64}$ reduction of the nitro group and final acylation by dibromopyrrole carboxylic acid in presence of the coupling reagent $\mathrm{T}_{3} \mathrm{P}$ (Scheme 10).

Scheme 10. Synthesis of derivatives with a meta and para benzene linker at C3.

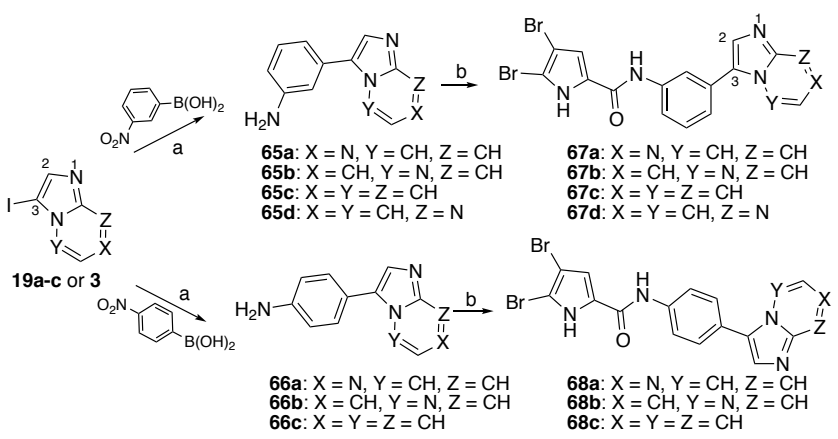

Reagents and conditions: (a) i. Pd-118, $\mathrm{K}_{2} \mathrm{PO}_{4}$, dioxane $/ \mathrm{H}_{2} \mathrm{O}$, $80^{\circ} \mathrm{C}$, ii. $\mathrm{SnCl}_{2} .2 \mathrm{H}_{2} \mathrm{O}, \mathrm{EtOH} / \mathrm{HCl}$, reflux; (b) Dibromopyrrole carboxylic acid, $\mathrm{T}_{3} \mathrm{P}$, pyridine, EtOAc/DMF.

We also prepared derivatives comprising 1,2,3-triazole as a proton acceptor linker. Thus, bicyclic intermediates 18a-c underwent a hydromethylation reaction in $37 \%$ formaldehyde solution. ${ }^{65}$ The hydroxy group was replaced by an azide using $\mathrm{NaN}_{3}$ under acidic conditions. ${ }^{66}$ The azidomethylimidazoles were then coupled with dibromopyrrole alkynes via the $\mathrm{CuSO}_{4}$ mediated Huisgen click reaction to afford compounds 71a-c bearing a triazole linker with good yields (Scheme 11). ${ }^{67}$

Scheme 11. Synthesis of derivatives with a meta and para benzene linker at $\mathrm{C} 3$

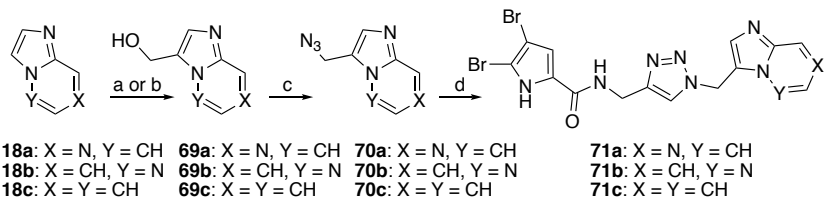

Reagents and conditions: (a) Formaldehyde $37 \%$ solution, $90^{\circ} \mathrm{C}$, $48 \%$; (b) formaldehyde $37 \%$ solution, $\mathrm{NaOAc}, \mathrm{AcOH}, 100{ }^{\circ} \mathrm{C}, 50-$ $73 \%$; (c) TFA, $\mathrm{NaN}_{3}, 70^{\circ} \mathrm{C}, 56-77 \%$; (d) $15 \mathrm{a}, \mathrm{CuSO}_{4} .5 \mathrm{H}_{2} \mathrm{O} 1$ mol\%, Sodium ascorbate $10 \mathrm{~mol} \%, \mathrm{DMF} / \mathrm{H}_{2} \mathrm{O}, 63-89 \%$. 
Biological Evaluation and Structure-Activity Relationship Study.

The above chemical library of new compounds was synthesized not only to create molecular diversity but also in response to results obtained from Aurora B kinase inhibition assessments during the course of our study. Kinase inhibition was measured using an ADPGlo methodology (ADP-Glo ${ }^{\mathrm{TM}}$ Assay kit, Promega). Preliminary screening was performed on several kinases including Aurora B, allowing identification of the first hit, EL228 (1). Later in the project, going back and forth between synthesis and biological activity tests permitted investigation of SAR and significant improvement of Aurora B kinase inhibition. The compounds were also assessed for their effects on cell viability on human HCT116 and K562 cell lines.

Structure-Activity Relationships of part A moiety. Starting from the first hit EL228 (1), various heterocycles (Table 1) were considered for the modification of part A (Figure 2). Replacement of the pyrrole moiety of EL-228 (1) by the regioisomeric bromothiophenes $(\mathbf{8 a}, \mathbf{8 b})$ and indoles $(\mathbf{8 c}, \mathbf{8 d})$ gave rise to analogs inactive against Aurora B (Table 1). We also explored the influence of the nature and the degree of halogen substitution on the pyrrole ring. Thus, compounds with two iodine atoms (16c), one bromine atom (16d), no halogen atom (16e) or having two methyl groups (11c) were less active than 1 or, completely inactive (16d-e). Only the dichlorinated pyrrole derivative $16 \mathrm{~b}$ was shown to be equipotent to El-228 (1). This suggests that the two bromine atoms on the pyrrole moiety are essential for the proper interaction with the kinase, probably due to halogen bond interaction with the protein. Interestingly, bromine and chlorine are better tolerated than iodine, which is probably too bulky. Replacing the $\mathrm{H}$-bond donating pyrrole unit of EL-228 (1) by H-bond acceptor units as in 11a and $11 \mathrm{~b}$ led to complete loss of inhibitory activity. We therefore chose to continue our SAR study using dibromopyrrole as the optimal part A moiety.

Table 1: SAR of part A moiety ( $\mathrm{IC}_{50}$ on Aurora B kinase activity were calculated from dose-response curves performed in duplicate).

11a

Structure-Activity Relationships of part B moiety. In our search for compounds more potent than EL-228 (1), we evaluated the derivatives $20 \mathrm{a}, \mathbf{2 0 b}$ and $20 \mathrm{c}$ built around an imidazopyrimidine fragment in which the nitrogen atom is now endocyclic or replaced by a carbon atom (Table 2). To our delight, the assays revealed that the most active Aurora B kinase inhibitor $\left(\mathrm{IC}_{50}=46.8 \mathrm{nM}\right)$ was the simplest imidazopyridine $20 \mathrm{c}$ while $20 \mathrm{a}$ and $20 \mathrm{~b}$ showed lower activities with $\mathrm{IC}_{50}$ 's of 190 and $350 \mathrm{nM}$, respectively. To further explore the influence of the nature of this heterocycle, it was replaced by other aromatic heterocycles including benzothiophene, indole, imidazole and pyridine derivatives (compounds 20d-20j) (Table 2 ). Interestingly, none of these compounds demonstrated significant activity. Retaining the imidazopyridine moiety as optimal for Aurora B inhibition, we next examined the effect of substituents on this ring system. Chloro-, bromo-, methyl- or trifluoromethyl substituents as in $\mathbf{2 4 a - 2 4 h}$ resulted in compounds less active or, at most, equipotent with the unsubstituted imidazopyridine 20c. Even the smaller fluoro substituent in $\mathbf{2 4} \mathbf{f}$ resulted in reduced activity. At this stage, we assumed that compounds with an $\mathrm{H}$-bond acceptor (mapped by the nitrogen in EL-228 (1)) at position 8 is not favorable for activity. Thus, we decided to prepare imidazopyridine derivatives 35, 37 and $\mathbf{4 3}$ having an $\mathrm{H}$-donor at $\mathrm{C} 8$. Our assays showed that the activity of $\mathbf{3 7}$ was only slightly superior to that of $20 \mathrm{c}$ but 150 times greater than that of the initial hit EL-228 (1), with an $\mathrm{IC}_{50}$ of $34.3 \mathrm{nM}$. The importance of a hydrogen donor at this position was confirmed by the compound $24 \mathrm{c}$ bearing a bromine C8 atom, which did not show any activity. Moreover, the imidazopyridine bearing a primary exocyclic amine at position 8 as in 
37 as well as a bromine atom at position 6 as in 43, also demonstrated good inhibitory activities with $\mathrm{IC}_{50}$ 's of $34.3 \mathrm{nM}$ and $71 \mathrm{nM}$, respectively.
On the other hand, azaindole analog 29, offering a reversed $\mathrm{H}$ bond donor and acceptor sequence compared to CJ2-150 (37), did not show any inhibitory activity against Aurora B We thus conclude that the imidazopyridine derivatives can be correlated with high activities.

Table 2: SAR of part B moiety ( $\mathrm{IC}_{50}$ on Aurora B kinase activity were calculated from dose-response curves performed in duplicate).

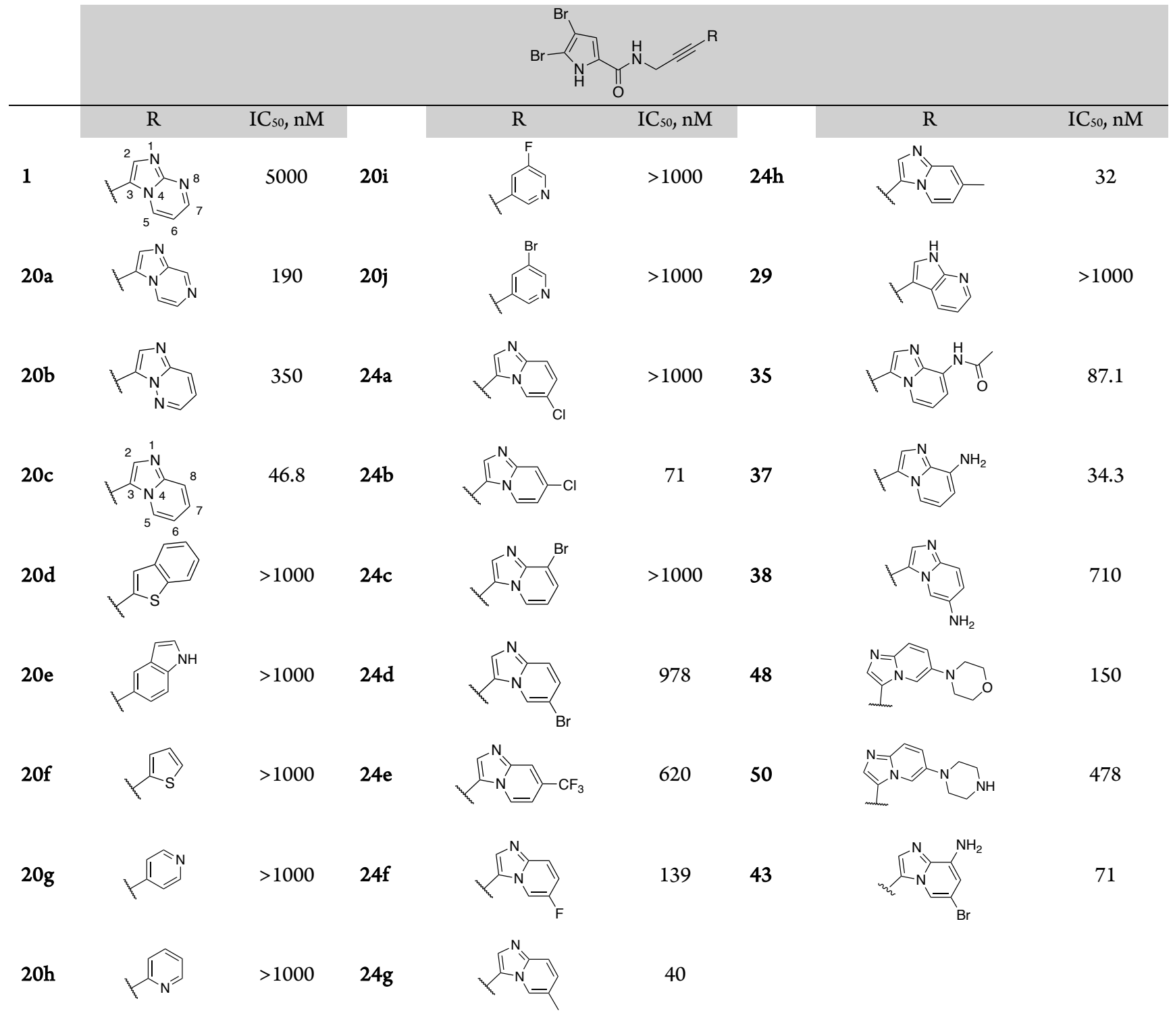

At this stage and in line with the above finding regarding the equipotency of the dichloropyrrole derivative $16 \mathrm{~b}$ (Table 1 ) with EL-228 (1), we chose to combine the activity-improving 8-aminoimidazopyridine unit of $\mathrm{CJ} 2-150$ (37) with the favorable dichloropyrrole and diiodopyrrole structural elements in 44 and 45
(Table 3). Of the dihalide analogs investigated, the dibromo and exoamino derivative 37 appeared to be the most active. The dibromopyrrole unit was thus retained as part $A$ of the molecules for the following pharmacomodulations.

Table 3: SAR with regard to various halides and bicyclic imidazoles ( $\mathrm{IC}_{50}$ on Aurora B kinase activity were calculated from dose-response curves performed in duplicate). 


(20),

Structure-Activity Relationships of Linker part $C$ modification. To examine whether the acetylene (part $C$ ), which serves as a linker between the pyrrole (part A) and the bicyclic platform (part B), binds these two parts in the most favorable way, we studied other linkers which allowed modification of the flexibility, the steric hindrance, the electronic distribution and the orientation angle between parts A and B of the molecule (Table 4).

Regardless of the nature of part B (pyrimidine, pyrazine, pyridazine, pyridine core), all the alternative linkers led to a dramatically decreased inhibition (Table 4). Only the alkene linker bearing the imidazopyrazine (56) and the para-phenyl linker combined with the imidazopyridine (68c) displayed appreciable activities with $\mathrm{IC}_{50}$ 's of $510 \mathrm{nM}$ and $150 \mathrm{nM}$, respectively. These activities were nevertheless almost three-fold less potent than their alkyne counterparts $20 \mathrm{a}$ and $20 \mathrm{c}$. Moreover, the selectivity over the panel of kinases was not optimal for these compounds. At this stage, we hypothesized that the linear alkyne linker, not overly sterically demanding, favorably reduces steric clash allowing the compound to fit within a tight hydrophobic pocket of the protein. This rigidification property of an acetylene linker has previously been pointed out in the literature as a means to improve the selectivity and potency of kinase inhibitors. ${ }^{68}$

Table 4: SAR with regard to various linkers and bicyclic imidazoles ( $\mathrm{IC}_{50}$ on Aurora B kinase activity were calculated from dose-response curves performed in duplicate)

200




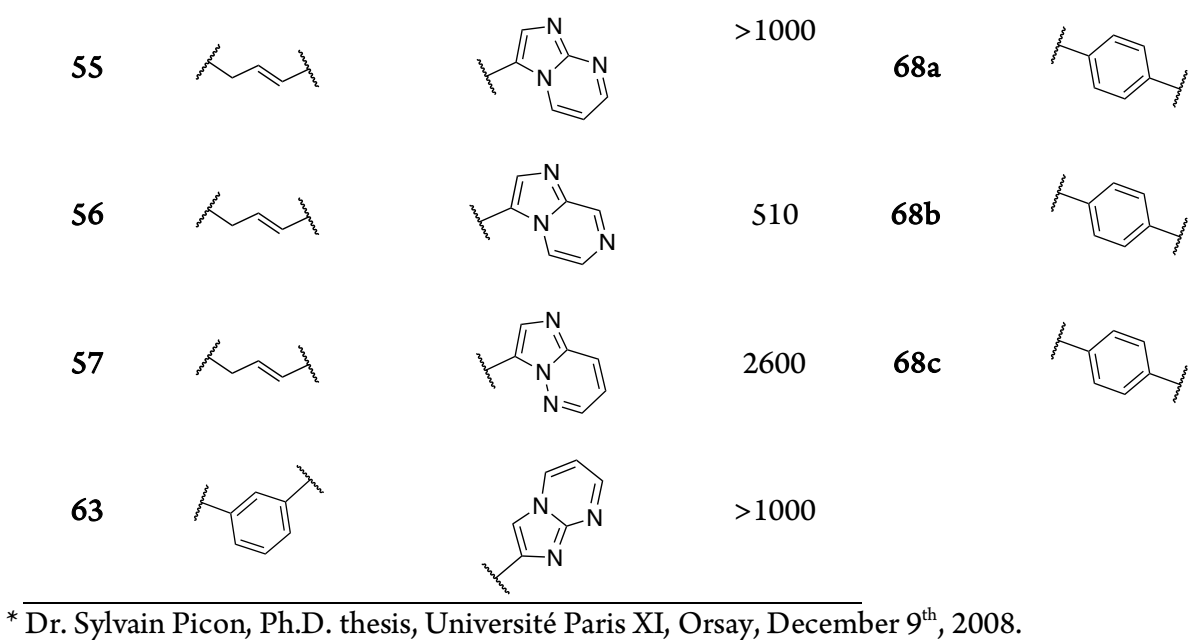

\section{Selectivity of Aurora B inhibition.}

To assess their selectivity, all the synthesized derivatives were first tested on a small panel of 8 kinases involved in many human disorders notably in cancer. The assays were conducted at $10 \mu \mathrm{M}$ and 1 $\mu \mathrm{M}$ concentrations and $\mathrm{IC}_{50}$ values were determined for all compounds showing greater than $50 \%$ inhibition at $10 \mu \mathrm{M}$. The results showed that the selected compounds on the running panel of kinases had significantly more activity on Aurora B than on all the other tested kinases. Importantly, all our products have been shown to be very active on Aurora B but inactive or significantly less active on most of the kinase panel.

At this stage, the good selectivity and potency displayed by our library of derivatives prompted us to evaluate one of these compounds on a larger panel of kinases. We thus evaluated compound CJ2-150 (37) for inhibitory activity on a panel of 58 protein kinases (Diversity Panel, Eurofins) covering a variety of associations with several cellular regulatory functions. The inhibition profile of CJ2-150 (37), evaluated at $1 \mu \mathrm{M}$, is illustrated in red in a phylogenetic tree format (Figure 3). Only Aurora A (the congener of Aurora $\mathrm{B}$ ) showed high inhibition (80\%). GSK3 $\beta$ and LYN kinases were $40 \%$ and $34 \%$ inhibited while all the other kinases were inhibited by less than $25 \%$. Note that CJ2-150, used at the same concentration of $1 \mu \mathrm{M}$, inhibited $88 \%$ of Aurora B kinase activity in an independent enzymatic assay (ADP-Glo, Promega) (See SI for values table). Interestingly, these results demonstrate a high selectivity for inhibition of Aurora family members by CJ2-150.

Antiproliferative profiles. The antiproliferative activity of active compounds, together with the reference Aurora B inhibitor ZM447439, was evaluated in dose-response experiments against the human cancer cell lines HCT116 (colorectal cancer) and K562 (myeloid leukemia) (Table 5). Compound 1, 20b and 24e had a mild effect on $\mathrm{K} 562$ cell viability with $\mathrm{EC}_{50 \text { s }}$ above $20 \mu \mathrm{M}$ together with little to no effect on HCT 116 cells. On the other hand, three compounds, $\mathbf{2 4 b}, \mathbf{2 4 f}$ and $\mathbf{2 4 g}$, showed an interesting specificity towards HCT 116 cell line with $\mathrm{EC}_{50}$ of 8,3 and $5 \mu \mathrm{M}$ respectively in the same order of magnitude as ZM447439 (EC $\mathrm{E}_{50}$ of $\left.7 \mu \mathrm{M}\right)$, and little or no effect on K562 cells. Four compounds, 37, 48 and 68c showed effect on cell viability on both cell lines in the range of 22 to $2 \mu \mathrm{M}$, similar to ZM447439 ( 7 and $9 \mu \mathrm{M}$ on HCT116 and K562 respectively). It is to be noted that there was no obvious correlation between the cell viability effect of the compounds and their potency on Aurora B kinase. The lack of effect from certain compounds having similar or higher potency to that of ZM447439 could be explained by their low solubility or lipophilicity.

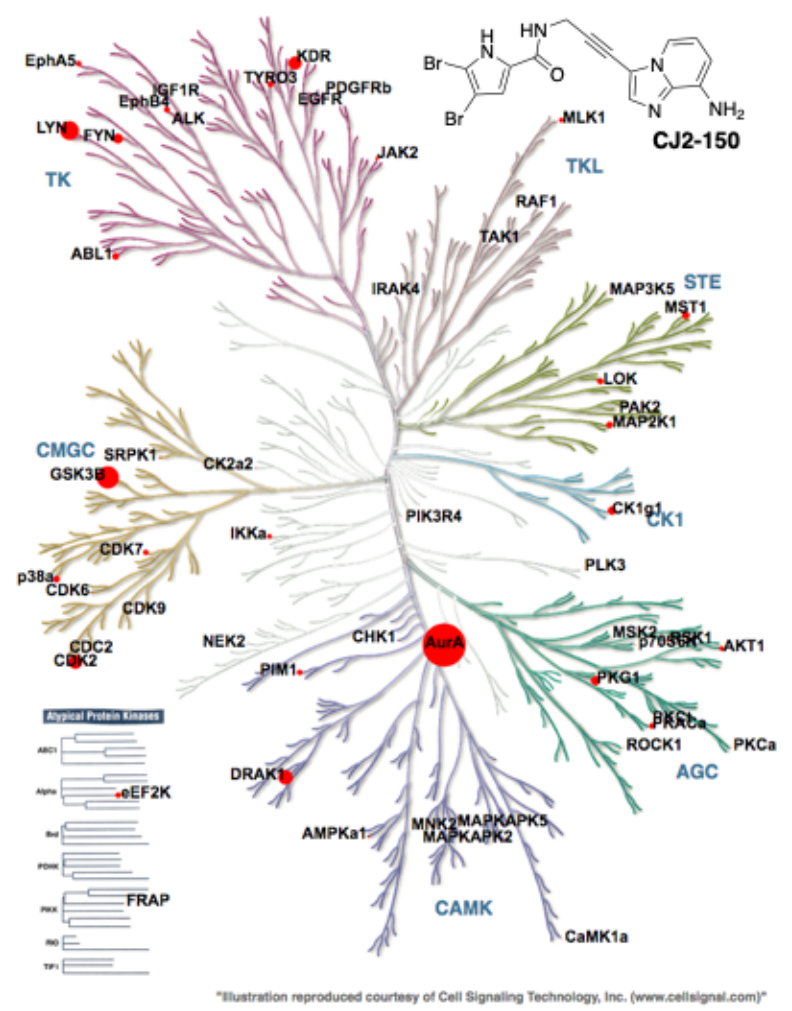

Figure 3: Kinase activity inhibition profile of CJ2-150 (37), screened against 58 kinases (at $1 \mu \mathrm{M}$ ) (Eurofins), illustrated on a human kinome phylogenetic tree (dendrogram, courtesy of Cell Signalling). Each kinase tested is marked and the size of the red circle is representative of the percentage of inhibition. Precise kinase inhibition percentages are shown in a table in SI.

Table 5: Effects on cell viability of HCT116 and K562 cancer cells. 


\begin{tabular}{rcccrcrc} 
& $\begin{array}{c}\text { Aurora B } \\
\mathrm{IC}_{50}(\mathrm{nM})\end{array}$ & $\begin{array}{c}\mathrm{HCT} 116 \\
\mathrm{EC}_{50}(\mu \mathrm{M})\end{array}$ & $\begin{array}{c}\mathrm{K} 562 \\
\mathrm{EC}_{50}(\mu \mathrm{M})\end{array}$ & $\begin{array}{c}\text { Aurora B } \\
\mathrm{IC}_{50}(\mathrm{nM})\end{array}$ & $\begin{array}{c}\mathrm{HCT} 116 \\
\mathrm{EC}_{50}(\mu \mathrm{M})\end{array}$ & $\begin{array}{c}\mathrm{K} 562 \\
\mathrm{EC}_{50}(\mu \mathrm{M})\end{array}$ \\
\hline $\mathbf{1}$ & 5000 & n.e. & 51 & $\mathbf{2 4 g}$ & 40 & 5 & n.e. \\
$\mathbf{2 0 a}$ & 180 & 15 & 44 & $\mathrm{CJ} 2-150(\mathbf{3 7})$ & 34 & 11 & 22 \\
$\mathbf{2 0 b}$ & 350 & 76 & 40 & $\mathbf{4 8}$ & 150 & 7 & 2 \\
$\mathbf{2 4 b}$ & 71 & 8 & 32 & $\mathbf{6 7 c}$ & $>1000$ & 9 & 22 \\
$\mathbf{2 4 e}$ & 620 & 93 & 21 & $\mathbf{6 8 c}$ & 150 & 12 & 8 \\
$\mathbf{2 4 f}$ & 139 & 3 & 66 & ZM447439 & 127 & 7 & 9 \\
\hline
\end{tabular}

$\mathrm{EC}_{50}(\mu \mathrm{M})$ on cell viability were calculated from dose-response curves made in triplicate after $72 \mathrm{~h}$ treatment. $\mathrm{IC}_{50}(\mathrm{nM})$ on Aurora $\mathrm{B}$ activity are reported in this table. "n.e.": no effect at maximal tested concentration of $100 \mu \mathrm{M}$.

The most interesting compound (in terms of enzymatic inhibition activity), the exocyclic amine substituted derivatives CJ2-150 (37) also showed interesting activity toward cell lines viability with $\mathrm{EC}_{50}$ of 11 and $22 \mu \mathrm{M}$ for HCT116 and K562 respectively (Table 5).

Therefore, we subsequently assessed the ability of this compound, in parallel with the reference ZM447439, to affect cell viability of various human cancerous cell lines from lung carcinoma A549, ovarian cancer SKOV3, breast cancer MCF7, osteosarcoma U-2 OS, as well as immortalized retinal fibroblast RPE-1 cell line ( Table 6). The results showed that CJ2-150 (37) as well as ZM447439 affected cell viability of all cell lines and that A549 lung carcinoma line was the most sensitive to both inhibitors with $\mathrm{EC}_{50}$ of 9 and 2 $\mu \mathrm{M}$ respectively. Overall, these last results showed that, interestingly, most of our compounds affect the viability of several cell lines of cancerous origin. In addition, we conducted CJ2-150 (37) doseresponse in viability assays on peripheral blood mononuclear cells (PBMCs) comparing non-proliferating to proliferating conditions i.e. activated with the mitogen phytohemagglutinine (PHA) (see SI Figure S1). We observed that cell viability of CJ2-150 (37)treated PBMCs was much less impacted $\left(\mathrm{EC}_{50}>100 \mu \mathrm{M}\right)$ than the proliferative condition performed with PHA $\left(30<\mathrm{EC}_{50}<100 \mu \mathrm{M}\right)$. These results showed that $\mathrm{CJ} 2-150$ (37) has very low cytotoxicity on PBMC. They further show that, as expected for an Aurora B inhibitor, proliferating cells are more affected than the non-proliferating ones.

Table 6: Effects of CJ2-150 and ZM447439 on cell viability of several human cell lines.

\begin{tabular}{cccccc} 
& A549 & SKOV3 & MCF7 & U2OS & RPE1 \\
\hline CJ2-150 (37) & 9 & 40 & 36 & 62 & 18 \\
ZM447439 & 2 & 31 & 4 & 29 & 27 \\
\hline
\end{tabular}

$\mathrm{EC}_{s 0}(\mu \mathrm{M})$ on cell viability were calculated from dose-response curves made in triplicate after $72 \mathrm{~h}$ treatment.

Mode of action. ATP competition assay with compound CJ2-150 (37). The binding mode of the most potent compound CJ2-150 (37) was investigated by performing experiments at varied ATP and inhibitor concentrations (Figure 4). The results are represented in Mickaelis-Menten and Lineweaver-Burk plots (Figure $4 A, C)$. They showed that in the presence of an excess of ATP, Aurora $\mathrm{B}$ activity (represented by $\mathrm{ADP}$ production) decreases in response to increasing concentrations of the inhibitor. Note that in an ATP-competition situation, Aurora B activity would not be impacted by any concentration of inhibitor when in the presence of an excess of ATP (in this case the 1/ADP production versus $1 /[\mathrm{ATP}]$ plots at different CJ2-150 concentrations should intersect on the $1 / \mathrm{ADP}$ production axis). Additionally, increasing inhibitor concentration was linked with $\mathrm{Km}$ increase suggesting a reduced affinity of the kinase for ATP. Similar results were obtained with compound 20c (see SI Figure S2). Furthermore, we observed that $\mathrm{CJ} 2-150 \mathrm{IC}_{50}$ measured at increasing concentration of ATP showed very little variation (from $39 \mathrm{nM}$ at $5 \mu \mathrm{M}$ ATP to $94 \mathrm{nM}$ at $75 \mu \mathrm{M}$ ATP) (Figure 4B). All together, these results strongly suggest that CJ2-150 does not compete directly with ATP, implying that the compound binds outside of the ATP pocket on an allosteric site, resulting in a mixed inhibition. They also suggest that this allosteric binding may affect the ATP pocket.

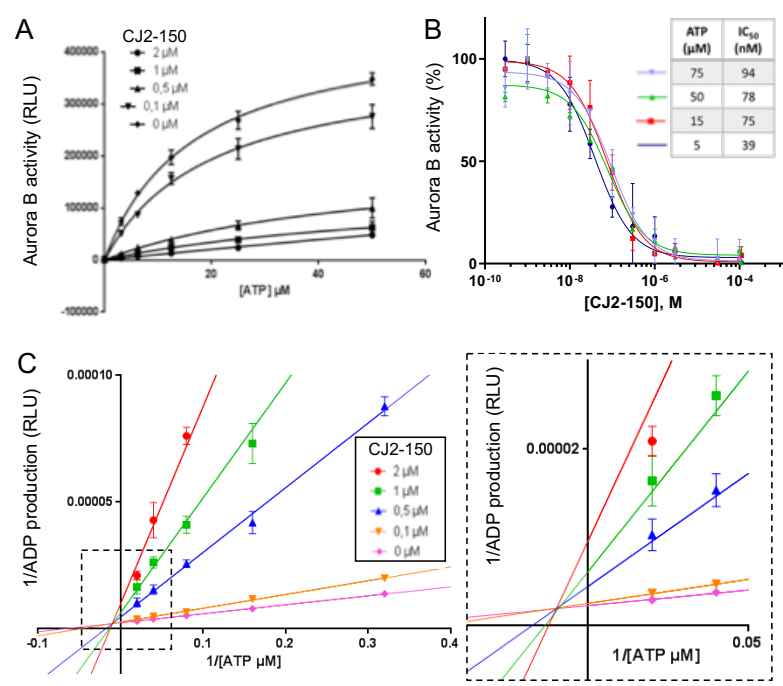


Figure 4: CJ2-150 (37) is a non-ATP-competitive Aurora B kinase inhibitor. A: ATP competition assay with compound CJ2-150 represented on a Mickaelis-Menten graph. Aurora B kinase activity assays were performed using ADP-Glo methodology (Promega) and conducted with increasing concentrations of $\mathrm{CJ} 2-150$ ranging from 0.1 to $2 \mu \mathrm{M}$ in the presence of increasing concentrations of ATP from 3.125 to $50 \mu \mathrm{M}$. ADP production in the reaction is directly proportional to Aurora $\mathrm{B}$ activity. B; Dose-response curves of CJ2-150 (from $2 \mathrm{nM}$ to $100 \mu \mathrm{M}$ ) on Aurora B activity at increasing concentrations of ATP (from 5 to $75 \mu \mathrm{M}$ ), corresponding calculated $\mathrm{IC}_{50}$ are showed in embedded table. C: ATP competition assay with compound $\mathrm{CJ} 2-150$ represented on a double reciprocal Lineweaver-Burk type plot; 1/ADP production expressed in RLU (Relative Light Unit) is plotted against 1/ATP concentration $(\mu \mathrm{M})$. All points are mean of triplicate \pm s.e.m.

Effect of compound CJ2-150 (37) on the cell cycle and mitotic progression. We next validated that the compound CJ2-150 effectively targets the Aurora B kinase in cells and assessed its impact on mitotic progression. Several key points were examined. Firstly, the DNA cell content following treatment was analyzed to highlight the polyploidy effect that is caused by cytokinesis failure on the K562 cell line upon Aurora B inhibition. Secondly, we investigated the signal intensity of Histone $\mathrm{H} 3$ phosphorylated on Ser10 in U2 OS mitotic cells; Histone $\mathrm{H} 3$ is a specific substrate of Aurora B. Lastly, we analyzed the distribution pattern of Aurora B during mitosis.

Cell cycle analysis. We examined the effect of our most active compound CJ2-150 at 2, 5, 10 and $20 \mu \mathrm{M}$ on the cell cycle of K562 cells after $48 \mathrm{~h}$ of treatment. The DNA content of the drug-treated cells and DMSO-treated cells (control) was analyzed by flow cytometry (FACS) allowing us to determine the percentage of cells in each phase of the cell cycle. After $48 \mathrm{~h}$, we observed a strong accumulation of cells with $4 \mathrm{~N}$ DNA contents and a part of the population reaching a DNA content of $8 \mathrm{~N}$ and above (Figure 5) in a clear dose-dependent effect. These results strongly suggested that treatment with CJ2-150 (37) resulted in impaired cell division and the generation of polyploid cells. This is indeed consistent with the essential role of Aurora B during the cytokinesis process. ${ }^{69}$ In support of these results, visual examination of cells revealed an important time-dependent increase in cell size.

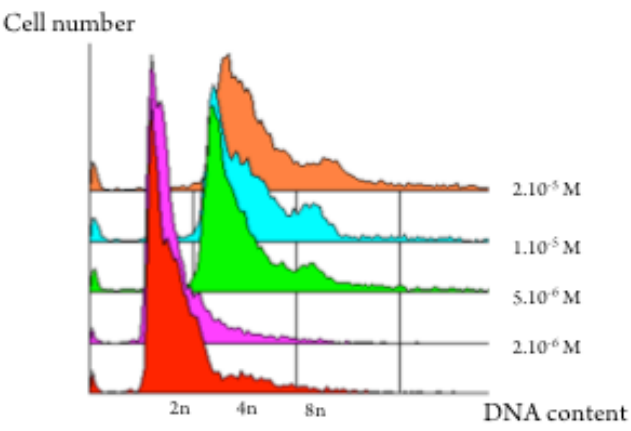

Figure 5: DNA content analysis in K562 cells treated with CJ2-150 (37) (for $48 \mathrm{~h}$ at indicated concentrations) by flow cytometry.

Phosphorylation of $\mathrm{H} 3$ on Ser10. In order to investigate the ability of CJ2-150 (37) to inhibit cellular endogenous Aurora B, we monitored the specific phosphorylation of histone $\mathrm{H} 3$ on serine 10 by immunofluorescence. For this purpose, we worked with U-2 OS adherent cells treated with CJ2-150 (37) at $10 \mu \mathrm{M}$ or ZM447439 at $1 \mu \mathrm{M}$ (Aurora B reference inhibitor) and a DMSO control.

After $16 \mathrm{~h}$ of treatment, we evaluated the levels of phospho-H3 on Ser10 (H3S10ph) by immunofluorescence and image analysis (Figure 6). Compared to the control, the H3S10ph signal was greatly reduced for both our compound and ZM447439 (Figure $6 \mathrm{~A})$. We noted that typical chromosome alignment and spindle defects were observed as previously reported in Aurora B depletion or inhibition experiments. ${ }^{70}$ Quantification of the H3S10ph signal versus the DAPI signal is represented in figure $6 \mathrm{~B}$. The strongest reduction in the $\mathrm{H} 3 \mathrm{~S} 10 \mathrm{ph}$ signal was obtained with compound CJ2-150 at $10 \mu \mathrm{M}$ similar to that obtained with ZM447439 at $1 \mu \mathrm{M}$. The effect was slightly milder with CJ2-150 at $2.5 \mu \mathrm{M}$. These results showed that the compound, displaying an in vitro inhibitory $\mathrm{IC}_{50}$ on Aurora B 3.7 times lower than that of ZM447439 (34 nM and $127 \mathrm{nM}$ respectively), required a 10 times higher concentration in cells in order to observe a level of inhibition comparable to that obtained with ZM447439 (Figure 6B). This discrepancy could be explained by different factors. It may result from the reduced solubility of CJ2-150 (37) in aqueous solution (cell culture media), or a lower affinity for lipid plasma membranes. Additionally, the compound can display a high metabolization rate: the amide function metabolic sensitivity and the heterocyclic probably bicycle make the molecule prone to metabolic instability. These structural weaknesses suggest the next step which is to design analogs with improved cellular activity while improving pharmacokinetic properties. Overall, these results demonstrate that CJ2-150 is functional on cellular Aurora B kinase activity. 

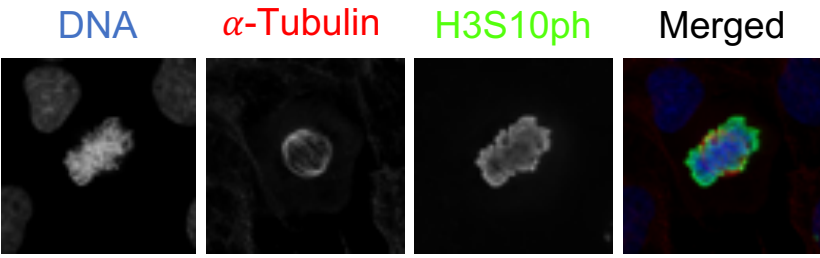

CJ2-150
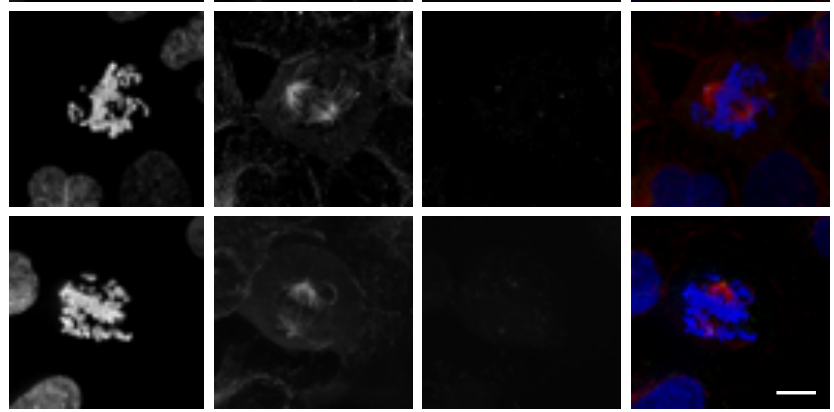

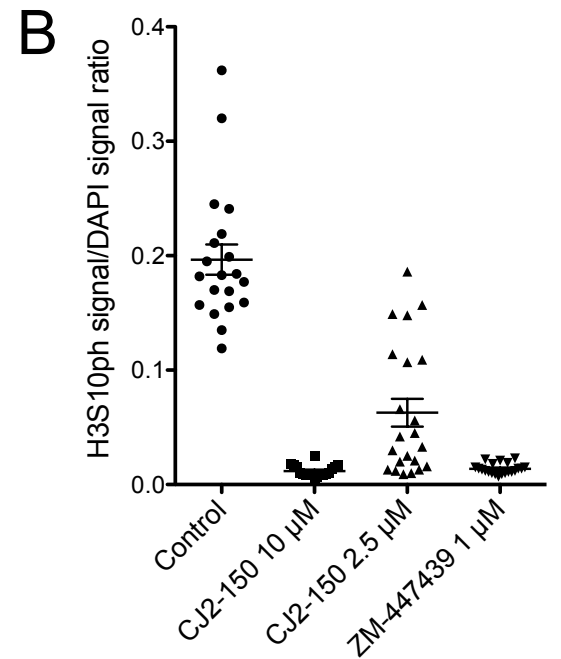

Figure 6: In-cell evaluation of Aurora B activity inhibition. A, immunofluorescence staining on U-2 OS cells treated with $10 \mu \mathrm{M}$ of CJ2-150 or $1 \mu \mathrm{M}$ of ZM447439 or DMSO (control) for $16 \mathrm{~h}$. Aurora B activity was monitored by immuno-staining of phosphorylated Histone H3 on serine 10 (H3S10ph, green); the cytoskeleton was visualized by $\alpha$-Tubulin immuno-staining (red) and DNA was visualized by DAPI staining (blue). Bar $10 \mu \mathrm{m}$. B, quantification of H3S10ph signal over DAPI signal, representative of Aurora B activity, in prometaphase cells from the experiment described in $\mathrm{A}, \mathrm{n} \geq 20$.

We next analyzed the different mitotic phenotypes resulting from the treatment with CJ2-150 (37) on U-2 OS cells. We first quantified the mitotic indexes and the proportion of cells in early and late mitosis after $16 \mathrm{~h}$ of treatment with CJ2-150 (37) (10 and $2.5 \mu \mathrm{M})$ or ZM447439 (1 $\mu \mathrm{M})$ and a DMSO control. We observed increased mitotic indexes after treatment with both CJ2-150 at 10 $\mu \mathrm{M}$ and ZM447439 compared to the DMSO control (7.6\% and $7.1 \%$ respectively compared to $4.5 \%$ ). A slight increase was observed with CJ2-150 used at $2.5 \mu \mathrm{M}(4.6 \%)$. An increased mitotic index is the result of a mitotic delay often generated by defects in early mitosis, a phenotype encountered when Aurora B activity or protein levels are affected. ${ }^{71,72}$ Indeed, chromosome misalignments activate the SAC (Spindle Assembly Checkpoint) and slow down mitotic progression leading to an accumulation of cells in early mitosis. Thus, we could observe early mitosis accumulation for both CJ2-150 (37) at $10 \mu \mathrm{M}$ and ZM447439 treatments (Figure 7B)
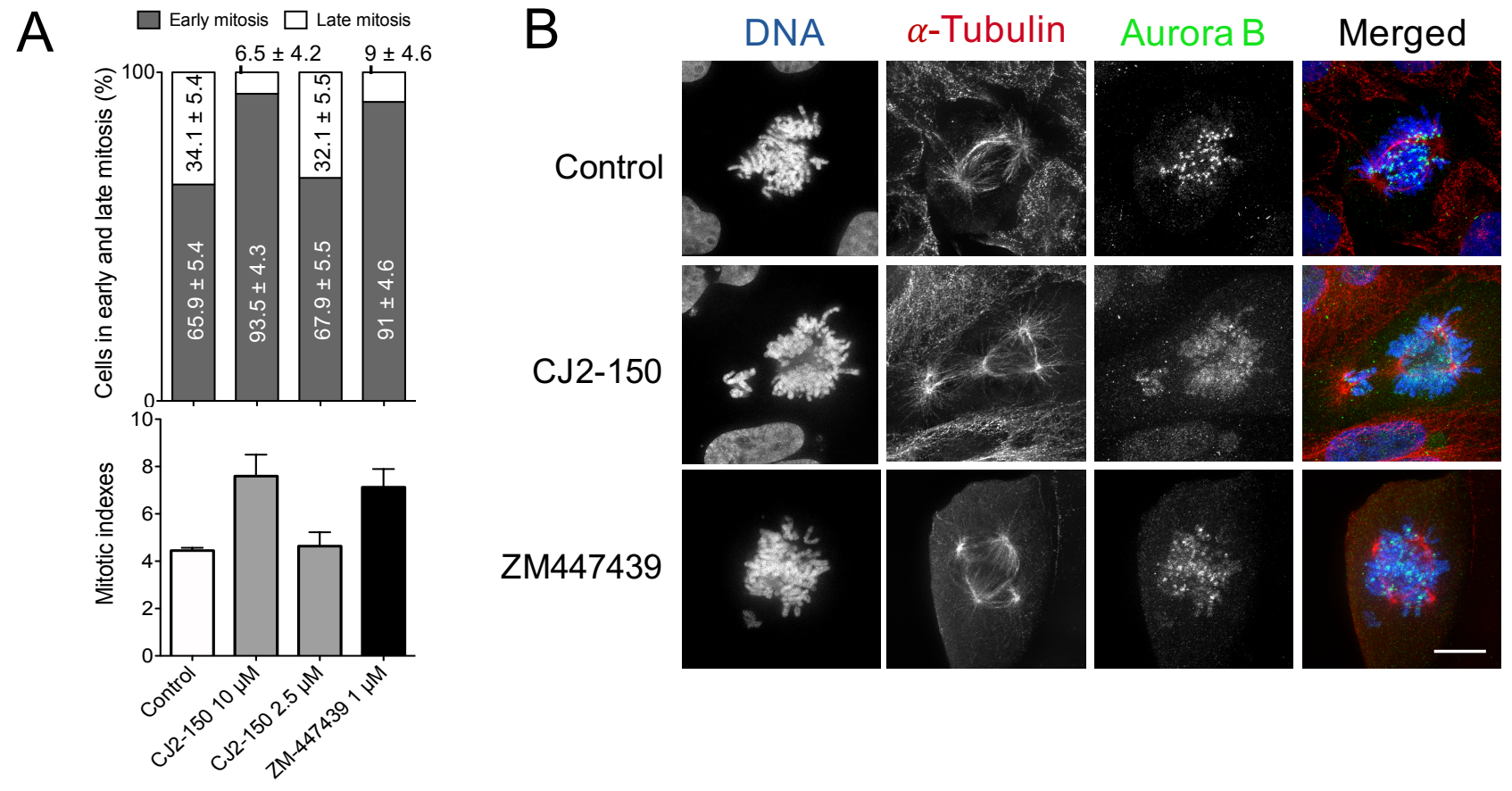

CJ2-150
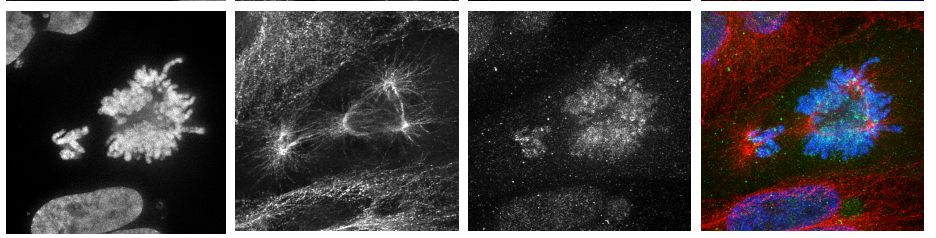

ZM447439
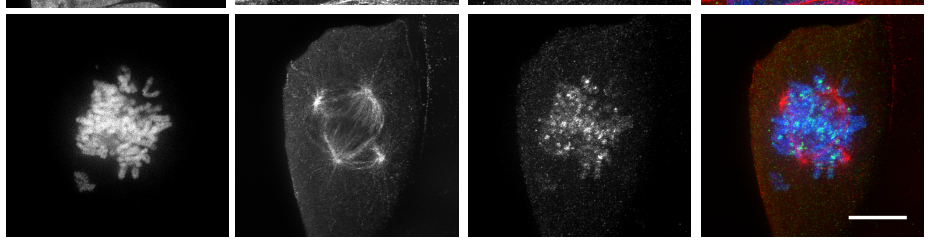
Figure 7: CJ2-150 (37) affects mitosis of U-2 OS cells. A, upper graph, quantification of early and late mitosis in U-2 OS cells treated with CJ2-150 (37) (10 and $2.5 \mu \mathrm{M})$ or ZM447439 (1 $\mu \mathrm{M})$ or DMSO (control) for $16 \mathrm{~h} . \mathrm{n} \geq 200$; graph represent the mean of 3 independent experiments; results are mean \pm s.e.m. Lower graph, quantification of mitotic indexes in cells treated as in A. $n \geq 500$; graph represent the mean of 3 independent experiments; results are mean \pm s.e.m. B, immunofluorescence staining of prometaphase U-2 OS cells treated with CJ2-150 $(10 \mu \mathrm{M})$ or ZM447439 $(1 \mu \mathrm{M})$ or DMSO for $24 \mathrm{~h}$. Aurora B is visualized in green, $\alpha$-Tubulin in red and DNA (DAPI) in blue. Scale bar $10 \mu \mathrm{m}$.

We thus examined the mitotic phenotypes of U-2 OS cells treated with CJ2-150 (37) and ZM447439 by immunofluorescence (Figure $7 \mathrm{~B}$. Aurora $\mathrm{B}$ and $\alpha$-tubulin staining allowed us to assess the kinase localization and spindle integrity respectively during mitosis. Aurora B clearly localized and concentrated at the centromere of control cells in prometaphase whereas for the cells treated with either CJ2-150 (37) or ZM447439, the kinase appeared delocalized from centromere to chromosome arms (Figure 7B). Indeed, Aurora $\mathrm{B}$, via a positive phosphorylation loop with Haspin kinase, is responsible for its proper localization at the centromere in early mitosis. ${ }^{73}$ The tubulin staining revealed a strong disrupting effect on spindles which often appeared multipolar. Taken together, these results showed that CJ2-150 (37) specifically acts on Aurora B kinase activity and therefore localization, impairing spindle structure, chromosome alignment and cytokinesis.

\section{Molecular docking.}

The mode of interaction of the most active compound, CJ2-150 (37) with Aurora B was investigated using molecular docking. Structural data available for Aurora B, includes only complexes with ATP-competitive ligands. However, three allosteric binding sites ("F", "Y" and "W") were identified for Aurora A, ${ }^{74,75,76}$ as well as their equivalents in Aurora B. ${ }^{77,78}$

The "W" site proved to be non-specific after a detailed analysis. ${ }^{74}$ We performed molecular docking of CJ2-150 (37) in the allosteric sites (type IV) "F" and "Y" of a representative Aurora B structure (PDB 4AF3), ${ }^{81}$ which provided a single cluster for the site "F" (Figure 8), whereas several clusters were obtained for the site " $Y$ ", with the bromine atoms exposed to the solvent in all of them. Therefore, although a binding in the " $\mathrm{Y}$ " site cannot be formally excluded, compound CJ2-150 (37) most likely interacts with the site "F", as shown in Figure 8 (see SI Figure S3 as well).

In this model, there is a very good shape complementarity between the ligand and the protein, with the imidazopyridine ring system buried in a hydrophobic subpocket formed by the residues Phe72, Phe77, Phe101, Val103, Tyr141 and Ile 153 and possible $\pi$-stacking interactions with Phe72 and Tyr141, whereas the pyrrole ring interacts with a second hydrophobic subpocket with favorable hydrophobic interactions between the two bromine atoms and the residues Ile126, Ala130 and Leu140. Hydrogen bonds are established between the amide oxygen of the ligand with the side chain of Arg139, and between the N-H of amide and pyrrole moieties in the ligand with the backbone O of Tyr141 and Leu140, respectively (Figure 8). Docking of compounds 35, 48 and 50 in the site "F" provided similar results. The docking conformation of $\mathbf{3 5}$ is exactly the same as for CJ2-150 (37), with the acetamide substituent deeply buried in the first subpocket. The same conformation is also observed for $\mathbf{4 8}$ and $\mathbf{5 0}$, with the exception of the imidazopyridine ring system, which is flipped towards the subpocket extremity, stabilized by a $\pi-\pi$ stacking with Phe 101 , but with the morpholine and piperazine substituents more solvent exposed (Figure S4). Overall, these docking results are in agreement with the SAR from Table 2 and strongly suggest a type IV allosteric inhibition. ${ }^{79}$ Neither the competitive non-ATP mode of action nor the type of mixed inhibition was described until October 2020.80

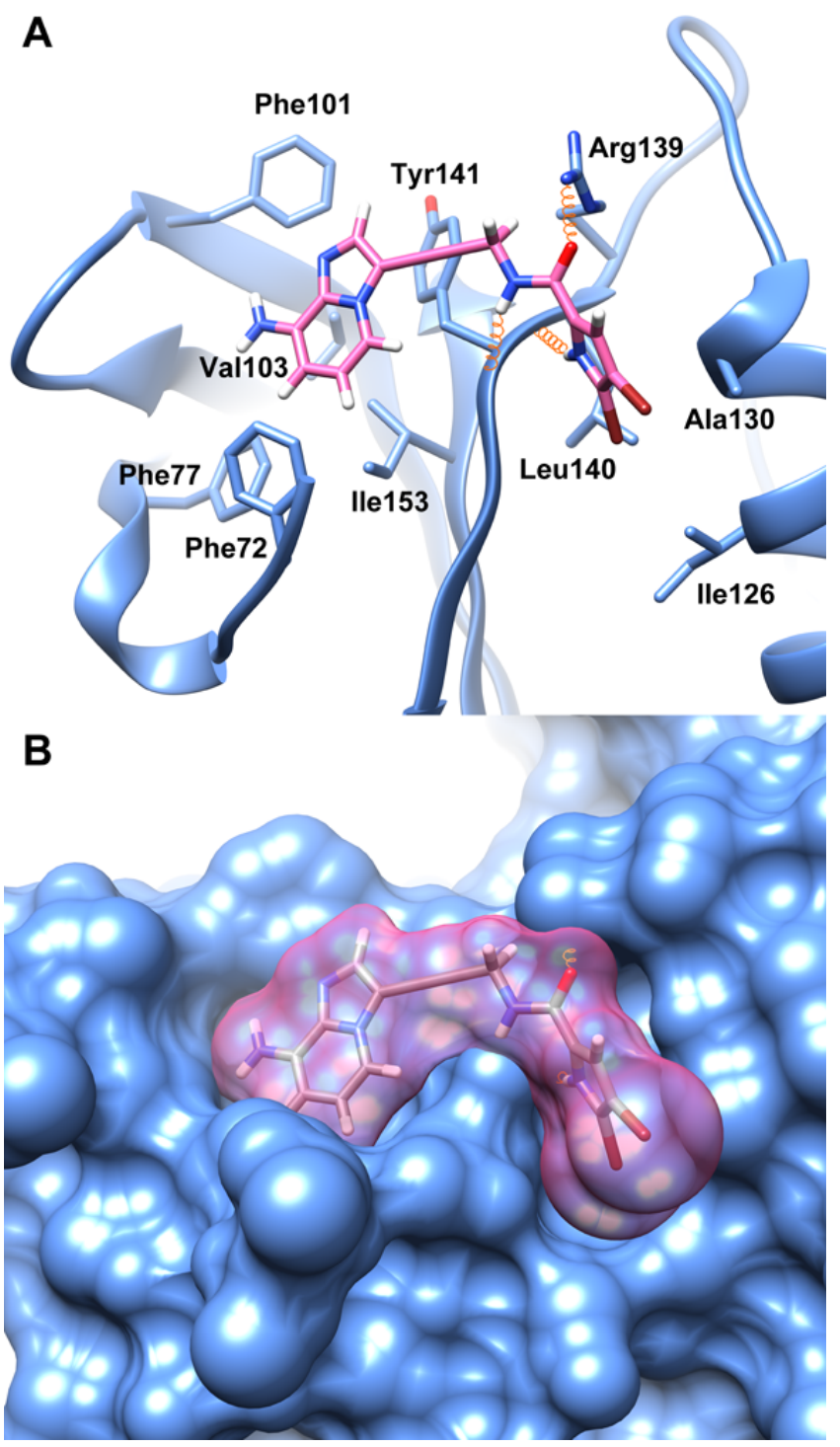

Figure 8: Docking conformation of CJ2-150, represented as pink sticks and transparent surface, into the allosteric site " $F$ " of Aurora $\mathrm{B}$ (PDB 4AF3) ${ }^{81}$ colored in blue in cartoon (A) or surface (B) representation. Hydrogen bonds are represented as orange springs.

\section{CONCLUSION}

In this report, new type IV allosteric inhibitors of Aurora B kinase are presented. Starting from the original marine benzosceptrin and oroidin pyrrole-2-aminoimidazole natural product analog EL-228 (1), pharmacomodulation by the chemical synthesis of 56 analogs 
and their systematic evaluation on Aurora B and others kinases was carried out. The rigid acetylenic structures were further optimized into CJ2-150 (37) with nanomolar activity and high selectivity for both Aurora A and B. Cell cycle and cellular effects in the presence of our compounds notably CJ2-150 resulted in impaired cell division and polyploid cells generation; consistent with the essential role of Aurora B in the cytokinesis process. Furthermore, we showed that CJ2-150 could inhibit in-cell Aurora B activity generating typical chromosome alignment, spindle and kinase

\section{EXPERIMENTAL SECTION}

All reagents were of commercial grade and were used without further purification, unless otherwise stated. Commercially available anhydrous solvents were used for reactions conducted under inert atmosphere. Reagent grade solvents were used in all other cases. Flash column chromatography was performed on silica gel 60 (70230 mesh, Macherey-Nagel). Thin layer chromatography was carried out using precoated silica gel F-254 plates (thickness 0.25 $\mathrm{mm})$ and visualized by UV light $(254 \mathrm{~nm})$. The purity of the final compounds was controlled by ELSD-HPLC using Kinetex C18 2.6 $\mathrm{x} 10 \mathrm{~mm}$, flow : $1 \mathrm{~mL} / \mathrm{min}$, eluent : $\mathrm{H}_{2} \mathrm{O}+0.1 \%$ formic acid/ACN $+0.1 \%$ formic acid by injection $10 \mu \mathrm{L}$ of $(1 \mathrm{mg} / \mathrm{mL}$ in $\mathrm{MeOH} / \mathrm{DMSO}: 7 / 3$. The ELSD-HPLC profiles showed that the purity of the majority of the final products is $>95 \%$ (see SI). $1 \mathrm{H}$ NMR also demonstrates the high purity of the final products (see SI). ${ }^{1} \mathrm{H}$ and ${ }^{13} \mathrm{C}$ NMR spectra were recorded on a Bruker Advance $300 \mathrm{NMR}$ spectrometer ( 300 and $75 \mathrm{MHz}$ ). Chemical shifts $\delta$ are reported in parts per million (ppm) relative to the residual solvent signals $\left(\mathrm{CDCl}_{3}, \delta=7.26\right.$ ppm for ${ }^{1} \mathrm{H}$ and $\delta=77.16$ ppm for ${ }^{13} \mathrm{C}$; DMSO-d6, $\delta=2.50 \mathrm{ppm}$ for ${ }^{1} \mathrm{H}$ and $\delta=39.52 \mathrm{ppm}$ for ${ }^{13} \mathrm{C}$. DMF$\mathrm{d} 7, \delta=2.79,2.92,8.03 \mathrm{ppm}$ for ${ }^{1} \mathrm{H}$ and $\delta=29.76,34.89,163.15$ ppm for $\left.{ }^{13} \mathrm{C}\right)$. Data are reported as follows: chemical shift, multiplicity $(\mathrm{s}=$ singlet, $\mathrm{d}=$ doublet, $\mathrm{t}=$ triplet, $\mathrm{q}=$ quartet, $\mathrm{m}=$ multiplet, $\mathrm{br}=$ broad $)$, coupling constants $(\mathrm{Hz})$ and integration. Highresolution MS data were obtained on a Waters LCT Micromass spectrometer in positive electrospray ionization-time of flight (ESI-TOF) mode. IR spectra were recorded on a PerkinElmer Spectrum 65 spectrophotometer using an attenuated total reflectance (ATR) device ( $v$ in cm-1). Reported yields are unoptimized. General Procedure A for Amide Synthesis.

To a solution of the appropriate carboxylic acid (1 eq.) in dry DCM were added HOBt (1.2 eq.), then EDC (1.2 eq.). DIEA was added ( 5 eq.) followed by the amine 7 ( 1 eq.). The mixture was stirred at room temperature until completion. The mixture was quenched with water and extracted with DCM. The combined organic layers were washed with water and brine, dried over $\mathrm{MgSO}_{4}$, filtered, and concentrated under vacuum. The product was purified by flash chromatography.

General Procedure B for Sonogashira coupling.

Appropriate halide (1eq.) was dissolved in either dry THF or dry $\mathrm{DMF}$ and $\mathrm{Et}_{3} \mathrm{~N}$ (2-3 eq.). The reaction mixture was degased by argon bubbling. CuI (5-10 \% mol) was introduced followed by $\mathrm{Pd}\left(\mathrm{PPh}_{3}\right)_{2} \mathrm{Cl}_{2}(2-5 \% \mathrm{~mol})$. Then the alkyne (1.5-2 eq.) was added to the mixture. The reaction mixture was stirred under inert atmosphere at room temperature or $50^{\circ} \mathrm{C}$ overnight. The mixture was concentrated under vacuum. The crude residue was purified by localization defects thus, validating its cellular functionality on Aurora B kinase. ATP-competition assay complemented with molecular docking showed that CJ2-150 (37) and compound 20c do not compete directly with ATP, but binds outside of the ATP pocket on an allosteric site (type IV) in a mixed-type inhibition. Our novel family of acetylenic compounds provides new entry to selective inhibitors of Aurora B since the selectivity of kinase inhibitors is often an inherent challenge for the types of inhibitors that target the highly conserved ATP binding pocket.

silica gel flash column chromatography and then on basic alumina gel to afford the expected product.

4,5-Dibromo- $N$-(3-(imidazo[1,2-a]pyrimidin-3-yl)prop-2-yn-1yl)-1 $H$-pyrrole-2-carboxamide (1). Compound 1 was synthesized according to general procedure $B$ using $15 \mathrm{a}(153 \mathrm{mg}, 0.5 \mathrm{mmol})$ and 3 (147 mg, $0.6 \mathrm{mmol}$ ). Purification afforded the title compound as a pale yellow solid $(110 \mathrm{mg}, 52 \%) .{ }^{1} \mathrm{H}$ NMR $(300 \mathrm{MHz}$, DMSO-d6) $\delta 4.44(\mathrm{~d}, J=5.3 \mathrm{~Hz}, 2 \mathrm{H}), 6.98(\mathrm{~s}, 1 \mathrm{H}), 7.24(\mathrm{~m}, 1 \mathrm{H})$, $8.05(\mathrm{~s}, 1 \mathrm{H}), 8.66(\mathrm{~m}, 1 \mathrm{H}), 8.76(\mathrm{t}, J=5.3 \mathrm{~Hz}, 1 \mathrm{H}), 8.88(\mathrm{~d}, J=6.6$ $\mathrm{Hz}, 1 \mathrm{H}), 12.82$ (s, 1H). ${ }^{13} \mathrm{C}$ NMR (75 MHz, DMSO-d6) $\delta 29.7$, $69.4,97.7,98.5,105.7,110.5,113.6,128,134.4,152$, 159.2. Some quaternary carbons and aromatic $\mathrm{CH}$ too broad to be seen due to very slow relaxation. HRMS (ESI) $\mathrm{m} / z$ Calcd for $(\mathrm{M}+\mathrm{H})^{+}$ $\mathrm{C}_{14} \mathrm{H}_{10} \mathrm{~N}_{5} \mathrm{OBr}_{2}$ : 423.9226. Found 423.9239. IR $\left(\mathrm{cm}^{-1}\right): 3107,1616$, $1558,1511,1395,1237,1142$.

3-Bromo- $N$-(3-(imidazo[1,2-a]pyrimidin-3-yl)prop-2-yn-1-

yl)thiophene-2-carboxamide (8a). The title compound was synthesized according to general procedure A using 3-bromothiophene-2-carboxylic acid (250 $\mathrm{mg}, 1.21 \mathrm{mmol}$ ) yielding $8 \mathrm{a}$ as a beige amorphous solid (244 mg, 56\%). ${ }^{1} \mathrm{H}$ NMR $(300 \mathrm{MHz}$, DMSO-d6) $\delta 4.45(\mathrm{~d}, J=5.4 \mathrm{~Hz}, 2 \mathrm{H}), 7.19(\mathrm{~d}, J=5.4 \mathrm{~Hz}, 1 \mathrm{H}), 7.26$ (dd, $J=4.2,2.8 \mathrm{~Hz}, 1 \mathrm{H}), 7.83(\mathrm{~d}, J=5.5 \mathrm{~Hz}, 1 \mathrm{H}), 8.05(\mathrm{~s}, 1 \mathrm{H})$, $8.65(\mathrm{dd}, J=2.1,2.1 \mathrm{~Hz}, 1 \mathrm{H}), 8.77(\mathrm{t}, J=5.1 \mathrm{~Hz}, 1 \mathrm{H}), 8.88(\mathrm{dd}, J$ $=1.8,5.1 \mathrm{~Hz}, 1 \mathrm{H}) .{ }^{13} \mathrm{C}$ NMR $(75 \mathrm{MHz}$, DMSO-d6) $\delta 30,68.8$, 96.8, 106.3, 110, 100.7, 130.2, 131.8, 132.3, 133.6, 138.7, 147.8, 151.5, 160.3. HRMS (ESI) $\mathrm{m} / z$ Calcd for $(\mathrm{M}+\mathrm{H})^{+}$ $\mathrm{C}_{14} \mathrm{H}_{10} \mathrm{BrN}_{4} \mathrm{OS}$ : 362.9738 . Found: 362.9742 . IR $\left(\mathrm{cm}^{-1}\right)$ : 3335 , 1630, 1616, 1514, 1484, 1276.

5-Bromo- $N$-(3-(imidazo[1,2-a]pyrimidin-3-yl)prop-2-yn-1-

yl)thiophene-3-carboxamide $(\mathbf{8 b})$. The title compound was synthesized according to general procedure A using 5-bromothiophene-3-carboxylic acid (250 $\mathrm{mg}, 1.21 \mathrm{mmol}$ ) yielding $\mathbf{8 b}$ as a beige amorphous solid (216 mg, $44 \%) .{ }^{1} \mathrm{H}$ NMR $(300 \mathrm{MHz}$, DMSO-d6) $\delta 4.44(\mathrm{~d}, J=5.6 \mathrm{~Hz}, 2 \mathrm{H}), 7.25(\mathrm{dd}, J=2.2,4 \mathrm{~Hz}, 1 \mathrm{H})$, $7.62(\mathrm{~d}, J=1.8 \mathrm{~Hz}, 1 \mathrm{H}), 8.04(\mathrm{~s}, 1 \mathrm{H}), 8.19(\mathrm{~d}, J=1.8 \mathrm{~Hz}, 1 \mathrm{H}), 8.64$ (dd, $J=2.3,2.3 \mathrm{~Hz}, 1 \mathrm{H}), 8.88(\mathrm{dd}, J=2.3,4.6 \mathrm{~Hz}, 1 \mathrm{H}), 8.96(\mathrm{t}, J$ $=5.3 \mathrm{~Hz}, 1 \mathrm{H}) .{ }^{13} \mathrm{C}$ NMR $(75 \mathrm{MHz}, \mathrm{DMSO}-\mathrm{d} 6) \delta 29.4,68.7,96.9$, 106.3, 110, 112.1, 129.3, 131.5, 133.8, 137.2, 138.7, 147.9, 151.5, 160.6. HRMS (ESI) $m / z$ Calcd for $(\mathrm{M}+\mathrm{H})^{+} \mathrm{C}_{14} \mathrm{H}_{10} \mathrm{BrN}_{4} \mathrm{OS}$ : 362.9738. Found: 362.9734 . IR $\left(\mathrm{cm}^{-1}\right): 3249,1658,1555,1512$, $1486,1424,1262$.

$N$-(3-(Imidazo[1,2-a]pyrimidin-3-yl)prop-2-yn-1-yl)-1 $H$-indole2 -carboxamide $(\mathbf{8 c})$. The title compound was synthesized according to general procedure A using $1 \mathrm{H}$-indole-2-carboxylic acid (200 $\mathrm{mg}, 1.24 \mathrm{mmol}$ ) yielding $\mathbf{8 c}$ as a yellow amorphous solid $(220 \mathrm{mg}$, 
$56 \%) .{ }^{1} \mathrm{H}$ NMR $(300 \mathrm{MHz}, \mathrm{DMSO}-\mathrm{d} 6) \delta 4.53(\mathrm{~d}, J=5.5 \mathrm{~Hz}, 2 \mathrm{H})$, $7.02(\mathrm{t}, J=7.8 \mathrm{~Hz}, 1 \mathrm{H}), 7.19(\mathrm{t}, J=8.4 \mathrm{~Hz}, 1 \mathrm{H}), 7.19(\mathrm{~s}, 1 \mathrm{H}), 7.25$ (dd, $J=2.2,4.5 \mathrm{~Hz}, 1 \mathrm{H}), 7.44(\mathrm{dd}, J=1.1,8.4 \mathrm{~Hz}, 1 \mathrm{H}), 7.62(\mathrm{~d}, J$ $=8.4 \mathrm{~Hz}, 1 \mathrm{H}), 8.06(\mathrm{~s}, 1 \mathrm{H}), 8.64(\mathrm{dd} J=1.9,4.3 \mathrm{~Hz}, 1 \mathrm{H}), 8.9$ (dd, $J=1.9,7.1 \mathrm{~Hz}, 1 \mathrm{H}), 9.1(\mathrm{t}, J=5.2 \mathrm{~Hz}, 1 \mathrm{H}), 11.7(\mathrm{~s}, 1 \mathrm{H}) .{ }^{13} \mathrm{C} \mathrm{NMR}$ (75 MHz, DMSO-d6) $\delta 29.3,68.6,97.2,103,106.3,109.9,112.3$, $119.7,121.5,123.5,126.9,131,133.7,136.5,138.7,147.9,151.5$, 160.9. HRMS (ESI+) $m / z$ Calcd for $(\mathrm{M}+\mathrm{H})^{+} \mathrm{C}_{18} \mathrm{H}_{14} \mathrm{~N}_{5} \mathrm{O}$ : 316.1198. Found: 316.1218 . IR $\left(\mathrm{cm}^{-1}\right): 3241,1631,1616,1553$, 13091257.

[1,2-a]pyrimidin-3-yl)prop-2-yn-1-yl)- $1 H$-indole-3-carboxamide (8d). The title compound was synthesized according to general procedure A using $1 \mathrm{H}$-indole-3-carboxylic acid $(200 \mathrm{mg}, 1.24$ mmol) yielding $8 \mathrm{~d}$ as a white amorphous solid $(64 \mathrm{mg}, 17 \%) .{ }^{1} \mathrm{H}$ NMR (300MHz, DMF-d7) $\delta 4.62(\mathrm{~d}, J=5.5 \mathrm{~Hz}, 2 \mathrm{H}), 7.19(\mathrm{~m}$, $2 \mathrm{H}), 7.3(\mathrm{dd}, J=4,6.9 \mathrm{~Hz}, 1 \mathrm{H}), 7.53(\mathrm{~d}, J=7.3 \mathrm{~Hz}, 1 \mathrm{H}), 8.05(\mathrm{~s}$, $1 \mathrm{H}), 8.26(\mathrm{~d}, J=3 \mathrm{~Hz}, 1 \mathrm{H}), 8.34(\mathrm{~d}, J=8.2 \mathrm{~Hz}, 1 \mathrm{H}), 8.6(\mathrm{t}, J=$ $5.2 \mathrm{~Hz}, 1 \mathrm{H}), 8.71(\mathrm{dd}, J=2,4.2 \mathrm{~Hz}, 1 \mathrm{H}), 9.02(\mathrm{dd}, J=1.9,6.8 \mathrm{~Hz}$, $1 \mathrm{H}), 11.22(\mathrm{~s}, 1 \mathrm{H}) .{ }^{13} \mathrm{C}$ NMR (75 MHz, DMF-d7) $\delta 28.9,68.2$, 98.1, 106.5, 110 (2C), 111.8, 120.5, 120.9, 121.9, 126.1, 128.1, 133.7, 136.1, 138.5, 147.8, 151.4, 164.4. HRMS (ESI) $\mathrm{m} / z$ Calcd for $(\mathrm{M}+\mathrm{H})^{+} \mathrm{C}_{18} \mathrm{H}_{14} \mathrm{~N}_{5} \mathrm{O}$ : 316.1198. Found: 316.1209.

4,5-Dibromo- $N$-(3-(imidazo[1,2-a]pyrimidin-3-yl)prop-2-yn-1yl)furan-2-carboxamide (11a). Compound 11a was synthesized according to general procedure B using $10 \mathrm{a}(245 \mathrm{mg}, 0.80 \mathrm{mmol})$ and $3(150 \mathrm{mg}, 0.61 \mathrm{mmol})$. Purification afforded the title compound as a white amorphous solid (104 mg, $40 \%) .{ }^{1} \mathrm{H}$ NMR (300MHz, DMSO-d6) $\delta 4.44(\mathrm{~d}, J=5.6 \mathrm{~Hz}, 2 \mathrm{H}), 7.25$ (dd, $J=4.1$, $6.8 \mathrm{~Hz}, 1 \mathrm{H}), 7.44(\mathrm{~s}, 1 \mathrm{H}), 8,05(\mathrm{~s}, 1 \mathrm{H}), 8.65(\mathrm{dd}, J=2.0,4.2 \mathrm{~Hz}$, $1 \mathrm{H}), 8.88$ (dd, $J=2.0,6.8 \mathrm{~Hz}, 1 \mathrm{H}), 9.17(\mathrm{t}, J=5.5 \mathrm{~Hz}, 1 \mathrm{H}) .{ }^{13} \mathrm{C}$ NMR (75 MHz, DMSO-d6) $\delta 29.2,68.8,96.6,103.4,106.3,110$, 118.1, 126.3, 133.8, 138.8, 147.9, 149, 151.6, 155.8. HMRS (ESI) $\mathrm{m} / z$ Calcd for $(\mathrm{M}+\mathrm{H})^{+} \mathrm{C}_{14} \mathrm{H}_{9} \mathrm{~N}_{4} \mathrm{O}_{2} \mathrm{Br}_{2}:$ 424.9072. Found: 424.9068. IR ( $\left.\mathrm{cm}^{-1}\right): 3214,3010,1681,1513,1485,1284,1192$.

4,5-Dibromo- $N$-(3-(imidazo[1,2-a]pyrimidin-3-yl)prop-2-yn-1yl)thiophene-2-carboxamide (11b). Compound $11 \mathbf{b}$ was synthesized according to general procedure B using $10 \mathrm{~b}$ (343 mg, 1.06 $\mathrm{mmol}$ ) and 3 (200 $\mathrm{mg}, 0.82 \mathrm{mmol})$. Purification afforded the title compound as a beige amorphous solid (174 mg, 48\%). ${ }^{1} \mathrm{H}$ NMR $(300 \mathrm{MHz}, \mathrm{DMSO}-\mathrm{d} 6) \delta 4.48(\mathrm{~d}, J=5.2 \mathrm{~Hz}, 2 \mathrm{H}), 7.26(\mathrm{dd}, J=4.1$, $6.7 \mathrm{~Hz}, 1 \mathrm{H}), 7.84(\mathrm{~s}, 1 \mathrm{H}), 8.08(\mathrm{~s}, 1 \mathrm{H}), 8.66(\mathrm{dd}, J=1.9,4.4 \mathrm{~Hz}$, $1 \mathrm{H}), 8.90(\mathrm{dd}, J=1.7,7.0 \mathrm{~Hz}, 1 \mathrm{H}), 9.29(\mathrm{t}, J=5.0 \mathrm{~Hz}, 1 \mathrm{H}) .{ }^{13} \mathrm{C}$ NMR (75 MHz, DMSO-d6) $\delta 29.8,69.1,96.4,106.3,110.1,114$, $117,130.8,133.9,139,140.4,147.9,151.6,159.1$. HMRS (ESI) $\mathrm{m} / z$ Calcd for $(\mathrm{M}+\mathrm{H})^{+} \mathrm{C}_{14} \mathrm{H}_{9} \mathrm{~N}_{4} \mathrm{OSBr}_{2}$ : 440.8843. Found: 440.8851. IR $\left(\mathrm{cm}^{-1}\right): 3217,2979,1645,1512,1290,1230$.

$N$-(3-(Imidazo[1,2-a]pyrimidin-3-yl)prop-2-yn-1-yl)-4,5-dimethyl-1 $H$-pyrrole-2-carboxamide (11c). Compound 11c was synthesized according to general procedure B using $10 \mathrm{c}(129 \mathrm{mg}, 0.73$ $\mathrm{mmol}$ ) and 3 ( $150 \mathrm{mg}, 0.61 \mathrm{mmol})$. Purification afforded the title compound as an orange amorphous solid (94 mg, $52 \%) .{ }^{1} \mathrm{H}$ NMR (300MHz, DMSO-d6) $\delta 1.91(\mathrm{~s}, 3 \mathrm{H}), 2.10(\mathrm{~s}, 3 \mathrm{H}), 4.40$ (d, $J=5.5$ $\mathrm{Hz}, 2 \mathrm{H}), 6.57(\mathrm{~d}, J=2.3 \mathrm{~Hz}, 1 \mathrm{H}), 7.24(\mathrm{dd}, J=4.2,6.8 \mathrm{~Hz}, 1 \mathrm{H})$, $8.03(\mathrm{~s}, 1 \mathrm{H}), 8,32(\mathrm{t}, J=5.3 \mathrm{~Hz}, 1 \mathrm{H}), 8.64(\mathrm{dd}, J=2.0,4.1 \mathrm{~Hz}, 1 \mathrm{H})$, $8.87(\mathrm{dd}, J=2.0,6.9 \mathrm{~Hz}, 1 \mathrm{H}), 11.07(\mathrm{~s}, 1 \mathrm{H}) .{ }^{13} \mathrm{C} \mathrm{NMR}(75 \mathrm{MHz}$, DMSO-d6) $\delta 10.6,10.7,29,68.2,97.9,106.5,110,112,114.6$, 122.4, 128.7, 133.7, 138.5, 147.8, 151.5, 160.5. HMRS (ESI) $\mathrm{m} / z$ Calcd for $(\mathrm{M}+\mathrm{H})^{+} \mathrm{C}_{16} \mathrm{H}_{16} \mathrm{~N}_{5} \mathrm{O}$ : 294.1355. Found: 294.1342. IR $\left(\mathrm{cm}^{-1}\right): 3267,3205,1618,1513,1486,1410,1262,1230,1146$.
4,5-Dichloro-N-(3-(imidazo[1,2-a]pyrimidin-3-yl)prop-2-yn-1yl)-1H-pyrrole-2-carboxamide (16b). Compound $16 \mathrm{~b}$ was synthesized according to general procedure B using $15 b$ ( $106 \mathrm{mg}, 0.49$ $\mathrm{mmol}$ ) and 3 (100mg, $0.41 \mathrm{mmol}$ ). Purification afforded the title compound as a pale yellow amorphous solid $(28 \mathrm{mg}, 21 \%) .{ }^{1} \mathrm{H}$ NMR (300MHz, DMSO-d6) $\delta 4.44(\mathrm{~d}, J=5.3 \mathrm{~Hz}, 2 \mathrm{H}), 6.96(\mathrm{~s}$, $1 \mathrm{H}), 7.25(\mathrm{t}, J=4.6 \mathrm{~Hz}, 1 \mathrm{H}), 8.05(\mathrm{~s}, 21 \mathrm{H}), 8.66(\mathrm{~m}, 1 \mathrm{H}), 8.78(\mathrm{t}$, $J=5.2 \mathrm{~Hz}, 1 \mathrm{H}), 8.88(\mathrm{~d}, J=6.6 \mathrm{~Hz}, 1 \mathrm{H}), 12.86$ (br s, $1 \mathrm{H}) .{ }^{13} \mathrm{C}$ NMR (75 MHz, DMSO-d6) $\delta 29.2,68.7,97.1,108.1,108.6,110$, $110.2,115.4,124.3,133.8,138.8,150.1,151.5,158.8$.

$N$-(3-(Imidazo[1,2-a]pyrimidin-3-yl)prop-2-yn-1-yl)-4,5-diiodo$1 \mathrm{H}$-pyrrole-2-carboxamide (16c). Compound $16 \mathrm{c}$ was synthesized according to general procedure B using $15 \mathrm{c}$ (196 mg, 0.49 $\mathrm{mmol}$ ) and 3 ( $120 \mathrm{mg}, 0.49 \mathrm{mmol})$. Purification afforded the title compound as a white amorphous solid (101 mg, $40 \%)$. ${ }^{1} \mathrm{H}$ NMR (300MHz, DMSO-d6) $\delta 4.43(\mathrm{~d}, J=5.2 \mathrm{~Hz}, 2 \mathrm{H}), 6.97(\mathrm{~d}, J=2.3$ $\mathrm{Hz}, 1 \mathrm{H}), 7.24(\mathrm{dd} J=4.2,6.8 \mathrm{~Hz}, 1 \mathrm{H}), 8.04(\mathrm{~s}, 1 \mathrm{H}), 8.66(\mathrm{~m}, 2 \mathrm{H})$, $8.88(\mathrm{~d}, J=6.8 \mathrm{~Hz}, 1 \mathrm{H}), 12.43(\mathrm{~s}, 1 \mathrm{H}) .{ }^{13} \mathrm{C} \mathrm{NMR}(75 \mathrm{MHz}$, DMSO-d6) $\delta 29.1,68.6,76.2,84.2,97.2,106.3,110,118.6,132.2$, 133.8, 138.7, 147,8, 151.5, 158.4. HMRS (ESI) $\mathrm{m} / z$ Calcd for $(\mathrm{M}+\mathrm{H})^{+} \mathrm{C}_{14} \mathrm{H}_{10} \mathrm{I}_{2} \mathrm{~N}_{5} \mathrm{O}: 517.8975$. Found: 517.8974. IR $\left(\mathrm{cm}^{-1}\right)$ : 3122, 1620, 1553, 1511, 1379, 1277, 1223.

4-Bromo- $N$-(3-(imidazo[1,2-a]pyrimidin-3-yl)prop-2-yn-1-yl)$1 \mathrm{H}$-pyrrole-2-carboxamide (16d). Compound $16 \mathrm{~d}$ was synthesized according to general procedure $B$ using $15 \mathrm{~d}$ and 3 . Purification afforded the title compound $(72 \%)$. ${ }^{1} \mathrm{H}$ NMR $(300 \mathrm{MHz}$, DMSO-d6) $\delta 4.44(\mathrm{~d}, J=4.3 \mathrm{~Hz}, 2 \mathrm{H}), 6.91(\mathrm{~m}, 1 \mathrm{H}), 7.03(\mathrm{~m}, 1 \mathrm{H})$, 7.25 (dd, $J=4.0,6.7 \mathrm{~Hz}, 1 \mathrm{H}), 8.07$ (br s, $1 \mathrm{H}), 8.66(\mathrm{~m}, 1 \mathrm{H}), 8.72$ $(\mathrm{t}, J=4.9 \mathrm{~Hz}, 1 \mathrm{H}), 8.89(\mathrm{~d}, J=5.9 \mathrm{~Hz}, 1 \mathrm{H}), 11.94(\mathrm{br} \mathrm{s}, 1 \mathrm{H}) .{ }^{13} \mathrm{C}$ NMR (75 MHz, DMSO-d6) $\delta 29.1,68.6,97.3,95.1,110.1,112$, $121.7,126.3,133.8,138.6,147.6,151.6,159.4$. Some quaternary carbons too broad to be seen due to very slow relaxation.

$N$-(3-(imidazo[1,2-a]pyrimidin-3-yl)prop-2-yn-1-yl)-1 $H$-pyrrole-2-carboxamide (16e). Compound $16 \mathrm{e}$ was synthesized according to general procedure $\mathrm{B}$ using $15 \mathrm{e}$ and 3 . Purification afforded the title compound ( $86 \%) .{ }^{1} \mathrm{H}$ NMR $(300 \mathrm{MHz}$, DMSOd6) $\delta 4.44(\mathrm{~d}, J=5.6 \mathrm{~Hz}, 2 \mathrm{H}), 6.10(\mathrm{~m}, 1 \mathrm{H}), 6.83(\mathrm{~m}, 1 \mathrm{H}), 6.89$ $(\mathrm{m}, 1 \mathrm{H}), 7.24(\mathrm{dd}, J=4.2,6.7 \mathrm{~Hz}, 1 \mathrm{H}), 8.04(\mathrm{~s}, 1 \mathrm{H}), 8.58(\mathrm{t}, J=$ $5.6 \mathrm{~Hz}, 1 \mathrm{H}), 8.65(\mathrm{dd}, J=2.0,4.1 \mathrm{~Hz}, 1 \mathrm{H}), 8.88(\mathrm{~d}, J=2.1,6.8 \mathrm{~Hz}$, $1 \mathrm{H}), 11.53$ (br s, $1 \mathrm{H}) .{ }^{13} \mathrm{C}$ NMR (75 MHz, DMSO-d6) $\delta 29,68.3$, 97.7, 106.4, 108.7, 110, 110.5, 121.8, 125.6, 133.7, 138.6, 147.8, $151.5,160.4$.

4,5-Dibromo- $N$-(3-(imidazo[1,2-a]pyrazin-3-yl)prop-2-yn-1-yl)$1 H$-pyrrole-2-carboxamide (20a). Compound 20a was synthesized according to general procedure B using $15 \mathrm{a}(125 \mathrm{mg}, 0.41$ $\mathrm{mmol})$ and $19 \mathrm{a}(100 \mathrm{mg}, 0.41 \mathrm{mmol})$. Purification afforded the title compound as a yellow amorphous solid (46mg, 27\%). ${ }^{1} \mathrm{H}$ NMR (300MHz, DMSO-d6) $\delta 4.45(\mathrm{~d}, J=5.6 \mathrm{~Hz}, 2 \mathrm{H}), 6.99(\mathrm{~d}, J=2.5$ $\mathrm{Hz}, 1 \mathrm{H}), 8.08$ (d, $J=4.5 \mathrm{~Hz}, 1 \mathrm{H}), 8.10(\mathrm{~s}, 1 \mathrm{H}), 8.51$ (dd, $J=1.3$, $4.5 \mathrm{~Hz}, 1 \mathrm{H}), 8.79(\mathrm{t}, J=5,3 \mathrm{~Hz}, 1 \mathrm{H}), 9.16(\mathrm{~d}, J=1.3 \mathrm{~Hz}, 1 \mathrm{H}), 12.83$ (s, 1H). ${ }^{13} \mathrm{C}$ NMR (75 MHz, DMSO-d6) $\delta 29.2,68.1,98,98.4$, 105.3, 108.9, 113.1, 118.6, 127.5, 130.5, 138.9, 140, 143.2, 158.8 . HRMS (ESI) $m / z$ Calcd for $(\mathrm{M}+\mathrm{H})^{+} \mathrm{C}_{14} \mathrm{H}_{10} \mathrm{~N}_{5} \mathrm{OBr}_{2}$ : 425.9211. Found: 425.9236. IR $\left(\mathrm{cm}^{-1}\right): 3280,2922,1657,1513,1412,1311$, 1221.

4,5-Dibromo- $N$-(3-(imidazo[1,2-b] pyridazin-3-yl)prop-2-yn-1yl)- $1 H$-pyrrole-2-carboxamide (20b). Compound $20 \mathrm{~b}$ was synthesized according to general procedure B using $15 \mathrm{a}$ ( $192 \mathrm{mg}, 0.78$ $\mathrm{mmol}$ ) and $19 \mathrm{~b}(200 \mathrm{mg}, 0.65 \mathrm{mmol})$. Purification afforded the 
title compound as a yellow amorphous solid (24 mg, 9\%). ${ }^{1} \mathrm{H}$ NMR (300MHz, DMSO-d6) $\delta 4.43(\mathrm{~d}, J=5.5 \mathrm{~Hz}, 2 \mathrm{H}), 6.99$ (d, $J=$ $2.8 \mathrm{~Hz}, 1 \mathrm{H}), 7.34(\mathrm{dd}, J=4.6,9 \mathrm{~Hz}, 1 \mathrm{H}), 8.07(\mathrm{~s}, 1 \mathrm{H}), 8.2(\mathrm{dd}, J=$ $1.5,9.2 \mathrm{~Hz}, 1 \mathrm{H}), 8.63(\mathrm{dd}, J=1.5,4.6 \mathrm{~Hz}, 1 \mathrm{H}), 8.78(\mathrm{t}, J=5.5 \mathrm{~Hz}$, $1 \mathrm{H}), 12.8$ (s, $1 \mathrm{H}) .{ }^{13} \mathrm{C}$ NMR (75 MHz, DMSO-d6) $\delta 28.9,69.1$, 96.5, 98, 105.2, 111.6, 113.1, 118.8, 126, 127.6, 138, 139, 144.7, 158.6. HRMS (ESI) $\mathrm{m} / z$ Calcd for $(\mathrm{M}+\mathrm{H})^{+} \mathrm{C}_{14} \mathrm{H}_{10} \mathrm{~N}_{5} \mathrm{OBr}_{2}$ : 425.9211. Found: 425.9229. IR $\left(\mathrm{cm}^{-1}\right): 3141,3119,1659,1562$, $1523,1293,1240$.

4,5-Dibromo- $N$-(3-(imidazo[1,2-a] pyridin-3-yl)prop-2-yn-1-yl)$1 H$-pyrrole-2-carboxamide (20c). Compound 20c was synthesized according to general procedure B using $15 \mathrm{a}(282 \mathrm{mg}, 0.92$ $\mathrm{mmol}$ ) and $19 \mathrm{c}(150 \mathrm{mg}, 0.62 \mathrm{mmol})$. Purification afforded the title compound as a beige amorphous solid (120mg, 46\%). ${ }^{1} \mathrm{H}$ NMR $(300 \mathrm{MHz}, \mathrm{DMSO}-\mathrm{d} 6) \delta 4.45(\mathrm{~d}, J=5.4 \mathrm{~Hz}, 2 \mathrm{H}), 6.99$ (d, $J=$ $1.9 \mathrm{~Hz}, 1 \mathrm{H}), 7.11(\mathrm{t}, J=6.8 \mathrm{~Hz}, 1 \mathrm{H}), 7.39$ (t, $J=7.3 \mathrm{~Hz}, 1 \mathrm{H}), 7.68$ $(\mathrm{d}, J=8.8 \mathrm{~Hz}, 1 \mathrm{H}), 7.9(\mathrm{~s}, 1 \mathrm{H}), 8.46(\mathrm{~d}, J=6.6 \mathrm{~Hz}, 1 \mathrm{H}), 8.75(\mathrm{t}, J$ $=5.2 \mathrm{~Hz}, 1 \mathrm{H}), 12.8(\mathrm{~s}, 1 \mathrm{H}) \cdot{ }^{13} \mathrm{C}$ NMR (75 MHz, DMSO-d6) $\delta$ 69.4, 97.2, 97.9, 105.5, 113.1, 113.6, 117.4, 125.2, 126.2, 127.6, 137.7, 158.7. HMRS (ESI) $\mathrm{m} / z$ Calcd for $(\mathrm{M}+\mathrm{H})^{+} \mathrm{C}_{15} \mathrm{H}_{11} \mathrm{~N}_{4} \mathrm{OBr}_{2}$ : 422.9279. Found: 422.9325. IR $\left(\mathrm{cm}^{-1}\right): 3137,3116,1646,1565$, $1402,1243$.

$N$-(3-(benzo[ $b]$ thiophen-2-yl)prop-2-yn-1-yl)-4,5-dibromo-1 $H$ pyrrole-2-carboxamide (20d). Compound $20 \mathrm{~d}$ was synthesized according to general procedure $B$ using $15 \mathrm{a}(100 \mathrm{mg}, 0.33 \mathrm{mmol})$ and $19 \mathrm{~d}$ ( $84 \mathrm{mg}, 0.39 \mathrm{mmol})$. Purification afforded the title compound as a yellow amorphous solid (34 mg, $24 \%$ ). ${ }^{1} \mathrm{H}$ NMR (300MHz, DMF-d7) $\delta 4.46(\mathrm{~d}, J=5.7 \mathrm{~Hz}, 2 \mathrm{H}), 7.10(\mathrm{~s}, 1 \mathrm{H}), 7.45$ $(\mathrm{m}, 2 \mathrm{H}), 7.66(\mathrm{~s}, 1 \mathrm{H}), 7.89(\mathrm{~m}, 1 \mathrm{H}), 7.99(\mathrm{~m}, 1 \mathrm{H}), 8.97(\mathrm{t}, J=$ $5.7 \mathrm{~Hz}, 1 \mathrm{H}), 13.09$ (bd s, $1 \mathrm{H}) .{ }^{13} \mathrm{C} \mathrm{NMR}(75 \mathrm{MHz}, \mathrm{DMF}-\mathrm{d} 7) \delta 29$, 75.2, 93, 98.4, 105.1, 113.5, 122.3, 122.4, 124.2, 125.1, 125.9, $128.4,129.4,139.3,139.8$, 159. HRMS (ESI) $\mathrm{m} / z$ Calcd for $(\mathrm{M}+\mathrm{H})^{+} \mathrm{C}_{16} \mathrm{H}_{11} \mathrm{Br}_{2} \mathrm{~N}_{2} \mathrm{OS}$ : 436.8959 . Found: 436.9008.

$\mathrm{N}$-(3-(1H-indol-5-yl)prop-2-yn-1-yl)-4,5-dibromo-1 $H$-pyrrole-2carboxamide (20e). Compound $20 \mathrm{e}$ was synthesized according to general procedure B using 15a $(200 \mathrm{mg}, 0.65 \mathrm{mmol})$. Purification afforded the title compound as a beige amorphous solid $(25 \mathrm{mg}, 10$ \%). ${ }^{1} \mathrm{H}$ NMR (300MHz, DMSO-d6) $\delta 4.28(\mathrm{~d}, J=5.6 \mathrm{~Hz}, 2 \mathrm{H})$, $6.42(\mathrm{~s}, 1 \mathrm{H}), 7(\mathrm{~d}, J=2.8 \mathrm{~Hz}, 1 \mathrm{H}), 7.11(\mathrm{dd}, J=1.4,8.4 \mathrm{~Hz}, 1 \mathrm{H})$, $7.37(\mathrm{~m}, 1 \mathrm{H}), 7.39(\mathrm{~m}, 1 \mathrm{H}), 7.64(\mathrm{~s}, 1 \mathrm{H}), 8.66(\mathrm{t}, J=5.4 \mathrm{~Hz}, 1 \mathrm{H})$, 11.26 (s, 1H), 12.77 (s, 1H). ${ }^{13} \mathrm{C}$ NMR (75 MHz, DMSO-d6) $\delta$ 28.7, 83.7, 97.9, 101.2, 105, 111.7, 112.3, 113, 123.7, 124.3, 126.5, $127.5,127.7,135.5,158.5$. Some quaternary carbons and aromatic $\mathrm{CH}$ too broad to be seen due to very slow relaxation. HRMS (ESI) $\mathrm{m} / z$ Calcd for $(\mathrm{M}+\mathrm{H})^{+} \mathrm{C}_{16} \mathrm{H}_{12} \mathrm{Br}_{2} \mathrm{~N}_{3} \mathrm{O}$ : 421.9327. Found: 421.9356. IR $\left(\mathrm{cm}^{-1}\right): 3415,3154,1639,1556,1504,1236$.

4,5-Dibromo- $N$-(3-(thiophen-2-yl)prop-2-yn-1-yl)-1 $H$-pyrrole2-carboxamide (20f). Compound $20 \mathrm{f}$ was synthesized according to general procedure B using $15 \mathrm{a}(200 \mathrm{mg}, 0.65 \mathrm{mmol})$ and $19 \mathrm{f}$ $(0.1 \mathrm{~mL}, 0.92 \mathrm{mmol})$. Purification afforded the title compound as a yellow amorphous solid (92 mg, $36 \%) .{ }^{1} \mathrm{H}$ NMR $(300 \mathrm{MHz}$, DMF-d7) $\delta 4.40(\mathrm{~d}, J=5.6 \mathrm{~Hz}, 2 \mathrm{H}), 7.09(\mathrm{dd}, J=3.6,5.3 \mathrm{~Hz}, 1 \mathrm{H})$, $7.11(\mathrm{~d}, J=2.8 \mathrm{HZ}, 1 \mathrm{H}), 7.31(\mathrm{dd}, J=1.2,3.7 \mathrm{~Hz}, 1 \mathrm{H}), 7.61(\mathrm{dd}$, $J=1.2,5.2 \mathrm{~Hz}, 1 \mathrm{H}), 8.76(\mathrm{t}, J=5.5 \mathrm{~Hz}, 1 \mathrm{H}), 12.96(\mathrm{~s}, 1 \mathrm{H}) .{ }^{13} \mathrm{C}$ NMR (75 MHz, DMF-d7) $\delta 29.2,75.3,90.8,98.6,105.3,113.4$, $122.6,127.7,128.3,128.5,132.7,159$. HRMS (ESI) $\mathrm{m} / z$ Calcd for $(\mathrm{M}+\mathrm{H})^{+} \mathrm{C}_{12} \mathrm{H}_{9} \mathrm{Br}_{2} \mathrm{~N}_{2} \mathrm{OS}: 390.8761$. Found: 390.8794 .

4,5-Dibromo- $N$-(3-(pyridin-4-yl)prop-2-yn-1-yl)- $1 H$-pyrrole-2-

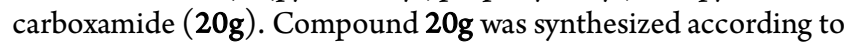

general procedure B using $15 \mathrm{a}(117 \mathrm{mg}, 0.38 \mathrm{mmol})$ and $19 \mathrm{~g}(106$ $\mathrm{mg}, 0.6 \mathrm{mmol}$ ). Purification afforded the title compound as a light yellow amorphous solid (43 mg, 22\%). ${ }^{1} \mathrm{H}$ NMR $(300 \mathrm{MHz}$, DMSO-d6) $\delta 4.32(\mathrm{~d}, \mathrm{~J}=5.7 \mathrm{~Hz}, 2 \mathrm{H}), 6.98(\mathrm{~s}, 1 \mathrm{H}), 7.39$ (d, J=6 $\mathrm{Hz}, 2 \mathrm{H}), 8.57(\mathrm{~m}, 2 \mathrm{H}), 8.72(\mathrm{t}, J=5.4 \mathrm{~Hz}, 1 \mathrm{H}), 12.79(\mathrm{~s}, 1 \mathrm{H}) .{ }^{13} \mathrm{C}$ NMR (75 MHz, DMSO-d6) $\delta 28.6,79.2,92,98,105.2,113.1$, $125.5,127.5,130.1,149.9,158.6$. Some quaternary carbons and aromatic $\mathrm{CH}$ too broad to be seen due to very slow relaxation. HRMS (ESI) $m / z$ Calcd for $(\mathrm{M}+\mathrm{H})^{+} \mathrm{C}_{13} \mathrm{H}_{10} \mathrm{Br}_{2} \mathrm{~N}_{3} \mathrm{O}: 383.9165$. Found 383.9187.

4,5-Dibromo-N-(3-(pyridin-2-yl)prop-2-yn-1-yl)-1H-pyrrole-2carboxamide $(20 \mathrm{~h})$. Compound $20 \mathrm{~h}$ was synthesized according to general procedure B using $15 \mathrm{a}(153 \mathrm{mg}, 0.5 \mathrm{mmol})$ and $19 \mathrm{~h}$ (123 $\mathrm{mg}, 0.6 \mathrm{mmol})$. Purification afforded the title compound as a light yellow amorphous solid (50 mg, 25\%). ${ }^{1} \mathrm{H}$ NMR (300 MHz, DMSO-d6) $\delta 4.31(\mathrm{~d}, \mathrm{~J}=5.5 \mathrm{~Hz}, 2 \mathrm{H}), 6.98(\mathrm{~d}, J=2.9 \mathrm{~Hz}, 1 \mathrm{H})$, 7.37 (ddd, $J=1.2,4.9,7.7 \mathrm{~Hz}, 1 \mathrm{H}), 7.49(\mathrm{dt}, J=1.1,7.7 \mathrm{~Hz}, 1 \mathrm{H})$, $7.79(\mathrm{td}, J=1.9,7.7 \mathrm{~Hz}, 1 \mathrm{H}), 8.54(\mathrm{~d}, J=4.8 \mathrm{~Hz}, 1 \mathrm{H}), 8.72(\mathrm{t}, J=$ $5.5 \mathrm{~Hz}, 1 \mathrm{H}), 12.79(\mathrm{~s}, 1 \mathrm{H}) .{ }^{13} \mathrm{C} \mathrm{NMR}(75 \mathrm{MHz}, \mathrm{DMSO}-\mathrm{d} 6) \delta 28.5$, 81.5, 86.5, 97.9, 105.2, 113.1, 123.4, 127, 127.5, 136.8, 142,1, 149.1, 158.7.HRMS (ESI) $\mathrm{m} / z$ Calcd for $(\mathrm{M}+\mathrm{H})^{+} \mathrm{C}_{13} \mathrm{H}_{10} \mathrm{Br}_{2} \mathrm{~N}_{3} \mathrm{O}$ : 383.9165. Found 383.9167.

4,5-Dibromo- $\mathrm{N}$-(3-(5-fluoropyridin-2-yl)prop-2-yn-1-yl)- $1 \mathrm{H}$ pyrrole-2-carboxamide (20i). Compound $20 \mathrm{i}$ was synthesized according to general procedure B using $15 \mathrm{a}(153 \mathrm{mg}, 0.5 \mathrm{mmol})$ and $19 \mathrm{i}$ ( $106 \mathrm{mg}, 0.6 \mathrm{mmol}$ ). Purification afforded the title compound as a light yellow amorphous solid (48 mg, 25\%). ${ }^{1} \mathrm{H}$ NMR (300 MHz, DMSO-d6) $\delta 4.30(\mathrm{~d}, J=5.4 \mathrm{~Hz}, 2 \mathrm{H}), 6.98(\mathrm{~d}, J=2.4 \mathrm{~Hz}$, $1 \mathrm{H}), 7.59(\mathrm{dd}, J=4.5,8.7 \mathrm{~Hz}, 1 \mathrm{H}), 7.74(\mathrm{dt}, J=3.0,9.3 \mathrm{~Hz}, 1 \mathrm{H})$, $8.55(\mathrm{~m}, 1 \mathrm{H}), 8.71(\mathrm{t}, J=5.4 \mathrm{~Hz}, 1 \mathrm{H}), 12.78(\mathrm{~s}, 1 \mathrm{H}) .{ }^{13} \mathrm{C} \mathrm{NMR}(75$ MHz, DMSO-d6) $\delta 28.4,80.5,86.4,98,105.2,113,123.9,127.5$, $128.6,138.3,138.5,156.7,158.6$. Some quaternary carbons are too broad to be seen due to very slow relaxation. HRMS (ESI) $\mathrm{m} / z$ Calcd for $(\mathrm{M}+\mathrm{H})^{+} \mathrm{C}_{13} \mathrm{H}_{9} \mathrm{Br}_{2} \mathrm{FN}_{3} \mathrm{O}$ : 401.9070. Found 401.9090.

4,5-Dibromo- $N$-(3-(5-bromopyridin-3-yl)prop-2-yn-1-yl)-1 $H$ pyrrole-2-carboxamide $(\mathbf{2 0} \mathbf{j})$. Compound $20 \mathrm{j}$ was synthesized according to general procedure B using $15 \mathrm{a}$ (142 mg, $0.46 \mathrm{mmol})$ and $19 j$ ( $110 \mathrm{mg}, 0.46 \mathrm{mmol}$ ). Purification afforded the title compound as a light yellow amorphous solid (61 mg, 27\%). ${ }^{1} \mathrm{H}$ NMR (300 MHz, DMSO-d6) $\delta 4.32(\mathrm{~d}, J=5.4 \mathrm{~Hz}, 2 \mathrm{H}), 6.97$ (d, $J=2.7$ $\mathrm{Hz}, 1 \mathrm{H}), 8.15(\mathrm{t}, J=1.8 \mathrm{~Hz}, 1 \mathrm{H}), 8.60(\mathrm{~d}, J=1.5 \mathrm{~Hz}, 1 \mathrm{H}), 8.70$ $(\mathrm{m}, 2 \mathrm{H}), 12.78(\mathrm{~s}, 1 \mathrm{H}) .{ }^{13} \mathrm{C}$ NMR (75 MHz, DMSO-d6) $\delta 28.6$, 77.1, 91.9, 98, 105.2, 113.1, 119.9, 120.9, 127.5, 140.7, 149.7, 150.2, 158.6. HRMS (ESI) $\mathrm{m} / z$ Calcd for $(\mathrm{M}+\mathrm{H})^{+} \mathrm{C}_{13} \mathrm{H}_{7} \mathrm{Br}_{3} \mathrm{~N}_{3} \mathrm{O}$ : 459.8124. Found 459.8113.

4,5-Dichloro-N-(3-(imidazo[1,2-a]pyrazin-3-yl)prop-2-yn-1-yl)$1 \mathrm{H}$-pyrrole-2-carboxamide (20k). Compound 20k was synthesized according to general procedure B using $15 \mathrm{~b}$ (133 mg, 0.61 $\mathrm{mmol}$ ) and $19 \mathrm{a}$ (100 mg, $0.41 \mathrm{mmol})$. Purification afforded the title compound as a yellow amorphous solid (90 mg, 66\%, \%). ${ }^{1} \mathrm{H}$ NMR (300MHz, DMSO-d6) $\delta 4.46(\mathrm{~d}, J=5.3 \mathrm{~Hz}, 2 \mathrm{H}), 6.96(\mathrm{~s}$, $1 \mathrm{H}), 8.08(\mathrm{~m}, 2 \mathrm{H}), 8.50(\mathrm{dd}, J=1.4,4.7 \mathrm{~Hz}, 1 \mathrm{H}), 8.79(\mathrm{t}, J=5.5$ $\mathrm{Hz}, 1 \mathrm{H}), 9.15$ (s, $1 \mathrm{H}), 12.85$ (br s, $1 \mathrm{H}) .{ }^{13} \mathrm{C}$ NMR $(75 \mathrm{MHz}$, DMSO-d6) $\delta 29.2$, 68.1, 98.4, 108.1, 109.2, 110.2, 115.4, 118.6, 124.2, 130.5, 138.9, 140, 143.2, 158.8. HMRS (ESI) m/z Calcd for $(\mathrm{M}+\mathrm{H})^{+} \mathrm{C} 14 \mathrm{H} 10 \mathrm{Cl} 2 \mathrm{~N} 5 \mathrm{O}: 334.0262$. Found: 334.0277. IR (cm-1): 3156, 3126, 1656, 1523, 1429, 1313.

$N$-(3-(imidazo[1,2-a]pyrazin-3-yl)prop-2-yn-1-yl)-4,5-diiodo1H-pyrrole-2-carboxamide (201). Compound 201 was synthesized 
according to general proce-dure B using $15 \mathrm{c}(149 \mathrm{mg}, 0.37 \mathrm{mmol})$ and $19 \mathrm{a}(70 \mathrm{mg}, 0.29 \mathrm{mmol})$. Purification afforded the title compound as a beige amorphous solid (95mg, 64\%). ${ }^{1} \mathrm{H}$ NMR (300MHz, DMSO-d6) $\delta 4.44(\mathrm{~d}, \mathrm{~J}=5.5 \mathrm{~Hz}, 2 \mathrm{H}), 6.97(\mathrm{~d}, J=2.6$ $\mathrm{Hz}, 1 \mathrm{H}), 8.1(\mathrm{~s}, 2 \mathrm{H}), 8.50(\mathrm{~d}, J=4.5 \mathrm{~Hz}, 1 \mathrm{H}), 8.68(\mathrm{t}, J=5.2 \mathrm{~Hz}$, 1H), 9.16 (br s, 1H), 12.43 (s, 1H). ${ }^{13} \mathrm{C}$ NMR (75 MHz, DMSOd6) $\delta 29.1,68.1,76.3,84.2,98.4,109,118.6,130.4,132.1,138.9$, 140.1, 143.2, 158.4. HMRS (ESI) $\mathrm{m} / \mathrm{z}$ Calcd for $(\mathrm{M}+\mathrm{H})^{+}$ C14H10I2N5O: 517.8975. Found: 517.8960. IR (cm-1): 3154, 1641, 1553, 1346, 1310, 1226.

4,5-Dichloro-N-(3-(imidazo[1,2-a]pyridin-3-yl)prop-2-yn-1-yl)$1 \mathrm{H}$-pyrrole-2-carboxamide $(20 \mathrm{~m})$. Compound $20 \mathrm{~m}$ was synthesized according to general pro-cedure B using $15 \mathrm{~b}$ (110 mg, 0.51 $\mathrm{mmol}$ ) and $19 \mathrm{c}(124 \mathrm{mg}, 0.51 \mathrm{mmol})$. Purification afforded the title compound as a white amorphous solid (63 mg, 37\%). ${ }^{1} \mathrm{H}$ NMR (300MHz, DMSO-d6) $\delta 4.45(\mathrm{~d}, J=5.3 \mathrm{~Hz}, 2 \mathrm{H}), 6.96(\mathrm{~s}, 1 \mathrm{H}, \mathrm{H} 4)$, $7.11(\mathrm{t}, J=6.9 \mathrm{~Hz}, 1 \mathrm{H}), 7.40(\mathrm{t}, J=7.9 \mathrm{~Hz}, 1 \mathrm{H}), 7.68(\mathrm{~d}, J=9.1$ $\mathrm{Hz}, 1 \mathrm{H}), 7.89(\mathrm{~s}, 1 \mathrm{H}), 8.45(\mathrm{~d}, J=6.7 \mathrm{~Hz}, 1 \mathrm{H}), 8.78(\mathrm{t}, J=5.6 \mathrm{~Hz}$, $1 \mathrm{H}), 12.85$ (s, 1H). ${ }^{13} \mathrm{C}$ NMR (75 MHz, DMSO-d6) $\delta 29.2,69.5$, 97.2, 108.1, 110.2, 115.4, 108.1, 113.6, 117.4, 124.3, 125.3, 126.2, 137.6, 144.9, 158.8. HMRS (ESI) $\mathrm{m} / \mathrm{z}$ Calcd for $(\mathrm{M}+\mathrm{H})^{+}$ C15H11Cl2N4O: 333.0310. Found: 333.0354. IR (cm-1): 3151, 1650, 1524, 1431, 1306, 1255.

$N$-(3-(imidazo[1,2-a]pyridin-3-yl)prop-2-yn-1-yl)-4,5-diiodo$1 \mathrm{H}$-pyrrole-2-carboxamide (20n). Compound 20n was synthesized according to general pro-cedure B using $15 \mathrm{c}(171 \mathrm{mg}, 0.43$ $\mathrm{mmol})$ and $19 \mathrm{c}(80 \mathrm{mg}, 0.33 \mathrm{mmol})$. Purification afforded the title compound as a beige amorphous solid (55 mg, 33\%). ${ }^{1} \mathrm{H}$ NMR (300MHz, DMSO-d6) $\delta 4.43(\mathrm{~d}, J=5.5 \mathrm{~Hz}, 2 \mathrm{H}), 6.98(\mathrm{~d}, J=2.7$ $\mathrm{Hz}, 1 \mathrm{H}), 7.11(\mathrm{t}, J=6.7 \mathrm{~Hz}, 1 \mathrm{H}), 7.39(\mathrm{t}, J=7.8 \mathrm{~Hz}, 1 \mathrm{H}), 7.68(\mathrm{~d}$, $J=7.8 \mathrm{~Hz}, 1 \mathrm{H}), 7.89(\mathrm{br} \mathrm{s}, 1 \mathrm{H}), 8.45(\mathrm{~d}, J=6.5 \mathrm{~Hz}, 1 \mathrm{H}), 8.66(\mathrm{t}, J$ $=5.3 \mathrm{~Hz}, 1 \mathrm{H}), 12.43(\mathrm{~s}, 1 \mathrm{H}) .{ }^{13} \mathrm{C} \mathrm{NMR}(75 \mathrm{MHz}, \mathrm{DMSO}-\mathrm{d} 6) \delta \mathrm{J}$ 29.2, 69.4, 76.2, 84.1, 97.3, 107.8, 113.6, 117.4, 118.6, 125.3, 126.2, $132.2,137.6,158.4$. Some quaternary carbons and aromatic $\mathrm{CH}$ too broad to be seen due to very slow relaxation. HMRS (ESI) m/z Calcd for $(\mathrm{M}+\mathrm{H})^{+} \mathrm{C}_{15} \mathrm{H}_{11} \mathrm{I}_{2} \mathrm{~N}_{4} \mathrm{O}$ : 516.9022. Found: 516.906. IR (cm-1): 3148, 1643, 1562, 1383, 1305, 1231.

4,5-Dibromo- $N$-(3-(6-chloroimidazo[1,2-a]pyridin-3-yl)prop-2yn-1-yl)-1 $H$-pyrrole-2-carboxamide (24a). Compound 24a was synthesized according to general procedure B using $15 \mathrm{a}(198 \mathrm{mg}$, $0.65 \mathrm{mmol}$ ) and 23a (150 mg, $0.54 \mathrm{mmol})$. Purification afforded the title compound as a beige amorphous solid $(75 \mathrm{mg}, 31 \%) .{ }^{1} \mathrm{H}$ NMR (300MHz, DMSO-d6) $\delta 4.46(\mathrm{~d}, J=5.5 \mathrm{~Hz}, 2 \mathrm{H}), 6.99(\mathrm{~d}, J$ $=2.8 \mathrm{~Hz}, 1 \mathrm{H}), 7.45(\mathrm{dd}, J=1.9,9.4 \mathrm{~Hz}, 1 \mathrm{H}), 7.73(\mathrm{~d}, J=9.4 \mathrm{~Hz}$, $1 \mathrm{H}), 7.94(\mathrm{~s}, 1 \mathrm{H}), 8.62(\mathrm{~s}, 1 \mathrm{H}), 8.74(\mathrm{t}, J=5.4 \mathrm{~Hz}, 1 \mathrm{H}), 12.80(\mathrm{~s}$, 1H). ${ }^{13} \mathrm{C}$ NMR (75 MHz, DMSO-d6) $\delta 29.2,68.8,98,98,105.2$, 108.7, 113.1, 118.3, 120.8, 123.2, 127.6, 127.1, 138.2, 143.4, 158.7. HMRS (ESI) $m / z$ Calcd for $(\mathrm{M}+\mathrm{H})^{+} \mathrm{C}_{15} \mathrm{H}_{10} \mathrm{~N}_{4} \mathrm{OBr}_{2} \mathrm{Cl}: 456.8889$. Found: 456.8891 . IR $\left(\mathrm{cm}^{-1}\right): 3158,1655,1561,1520,1489,1308$, 1242.

4,5-Dibromo- $N$-(3-(7-chloroimidazo[1,2-a] pyridin-3-yl)prop-2yn-1-yl)-1 $H$-pyrrole-2-carboxamide (24b). Compound 24b was synthesized according to general procedure B using 15a (169 mg, $0.55 \mathrm{mmol})$ and $23 \mathrm{~b}(62 \mathrm{mg}, 0.22 \mathrm{mmol})$. Purification afforded the title compound as a pale yellow amorphous solid (20 mg, $20 \%)$. ${ }^{1} \mathrm{H}$ NMR $(300 \mathrm{MHz}, \mathrm{DMSO}) \delta 4.44(\mathrm{~d}, J=5.4 \mathrm{~Hz}, 2 \mathrm{H}), 6.99$ (d, $J$ $=2.9 \mathrm{~Hz}, 1 \mathrm{H}) 7.18(\mathrm{dd} J=2.1,7.3 \mathrm{~Hz}, 1 \mathrm{H}), 7.88(\mathrm{~s}, 1 \mathrm{H}), 7.91(\mathrm{~s}$, 1H) $8.46(\mathrm{~d}, J=7.3 \mathrm{~Hz}, 1 \mathrm{H}), 8.75(\mathrm{t}, J=5.3 \mathrm{~Hz}, 1 \mathrm{H}), 12.80(\mathrm{~s}$, $1 \mathrm{H}) .{ }^{13} \mathrm{C}$ NMR (75 MHz, DMSO) $\delta 29.2,68.9,97.6,98,105.2$, $108.1,113.1,114.7,116.3,126.2,127.5,131.3,138.4,144.6,158.7$.
HMRS (ESI) $m / z$ Calcd for $(\mathrm{M}+\mathrm{H})^{+} \mathrm{C}_{15} \mathrm{H}_{10} \mathrm{~N}_{4} \mathrm{OBr}_{2} \mathrm{Cl}$ : 456.8889 . Found: 456.8879 .

4,5-Dibromo- $N$-(3-(8-bromoimidazo[1,2-a] pyridin-3-yl)prop-2yn-1-yl)-1 $H$-pyrrole-2-carboxamide (24c). Compound 24c was synthesized according to general procedure B using $15 \mathrm{a}(313 \mathrm{mg}$, $1.02 \mathrm{mmol})$ and $23 \mathrm{c}(220 \mathrm{mg}, 0.68 \mathrm{mmol})$. Purification afforded the title compound as a beige amorphous solid $(113 \mathrm{mg}, 33 \%) .{ }^{1} \mathrm{H}$ NMR (300MHz, DMSO-d6) $\delta 4.44(\mathrm{~d}, J=5.4 \mathrm{~Hz}, 2 \mathrm{H}), 6.99(\mathrm{~d}, J$ $=2.9 \mathrm{~Hz}, 1 \mathrm{H}), 7.03(\mathrm{t}, J=6.9 \mathrm{~Hz}, 1 \mathrm{H}), 7.74(\mathrm{dd}, J=0.9,7.2 \mathrm{~Hz}$, $1 \mathrm{H}), 7.94(\mathrm{~s}, 1 \mathrm{H}), 8.48(\mathrm{dd}, J=0.9,6.8 \mathrm{~Hz}, 1 \mathrm{H}), 8.75(\mathrm{t}, J=5.3$ $\mathrm{Hz}, 1 \mathrm{H}), 12.80(\mathrm{~s}, 1 \mathrm{H}) .{ }^{13} \mathrm{C}$ NMR $(75 \mathrm{MHz},-\mathrm{d} 6) \delta 29.2,69,97.6$, 98, 105.2, 109.6, 110.9, 113.1, 113.9, 125, 127.5, 128.7, 137.7, 142.5, 158.7. HMRS (ESI) $\mathrm{m} / z$ Calcd for $(\mathrm{M}+\mathrm{H})^{+} \mathrm{C}_{15} \mathrm{H}_{10} \mathrm{~N}_{4} \mathrm{OBr}_{3}$ : 498.8405. Found: 498.8423. IR $\left(\mathrm{cm}^{-1}\right): 3135,3116,1642,1560$, $1521,1398,1240,1212$.

4,5-Dibromo- $N$-(3-(6-bromoimidazo[1,2-a] pyridin-3-yl)prop-2yn-1-yl)-1 $H$-pyrrole-2-carboxamide (24d). Compound 24d was synthesized according to general procedure B using 15 a $(549 \mathrm{mg}$, $1.79 \mathrm{mmol})$ and $23 \mathrm{~d}(386 \mathrm{mg}, 1.2 \mathrm{mmol})$. Purification afforded the title compound as a pale yellow amorphous solid $(32 \mathrm{mg}, 5 \%) .{ }^{1} \mathrm{H}$ NMR (300MHz, DMSO-d6) $\delta 4.46(\mathrm{~d}, J=5.4 \mathrm{~Hz}, 2 \mathrm{H}), 6.99$ (s, $1 \mathrm{H}), 7.52(\mathrm{dd}, J=1.9,9.6 \mathrm{~Hz}, 1 \mathrm{H}), 7.68(\mathrm{~d}, \mathrm{~J}=9.6 \mathrm{~Hz}, 1 \mathrm{H}), 7.91$ (s, 1H), $8.67(\mathrm{~s}, 1 \mathrm{H}), 8.74(\mathrm{t}, J=5.3 \mathrm{~Hz}, 1 \mathrm{H}), 12.81$ (br s, $1 \mathrm{H})$. HMRS (ESI) $\mathrm{m} / z$ Calcd for $(\mathrm{M}+\mathrm{H})^{+} \mathrm{C}_{15} \mathrm{H}_{10} \mathrm{~N}_{4} \mathrm{OBr}_{3}$ : 500.8384 . Found: 500.8393. IR $\left(\mathrm{cm}^{-1}\right): 3152,1654,1561,1518,1407,1310$, 1222.

4,5-Dibromo- $N$-(3-(7-(trifluoromethyl)imidazo[1,2-a]pyridin-3yl)prop-2-yn-1-yl)-1 H-pyrrole-2-carboxamide (24e). Compound $24 \mathrm{e}$ was synthesized according to general procedure B using $15 \mathrm{a}$ (286 mg, $0.94 \mathrm{mmol}$ ) and 23e (122 mg, $0.62 \mathrm{mmol})$. Purification afforded the title compound as a pale yellow amorphous solid (173 $\mathrm{mg}, 57 \%) .{ }^{1} \mathrm{H}$ NMR $(300 \mathrm{MHz}, \mathrm{DMSO}-\mathrm{d} 6) \delta 4.46(\mathrm{~d}, J=5.6 \mathrm{~Hz}$, $2 \mathrm{H}), 6.99$ (d, $J=1.8 \mathrm{~Hz}, 1 \mathrm{H}), 7.37(\mathrm{~d}, J=7.1 \mathrm{~Hz}, 1 \mathrm{H}), 8.11(\mathrm{~s}$, $1 \mathrm{H}), 8.20(\mathrm{~s}, 1 \mathrm{H}), 8.65(\mathrm{~d}, J=7.1 \mathrm{~Hz}, 1 \mathrm{H}), 8.77(\mathrm{t}, J=5.4 \mathrm{~Hz}, 1 \mathrm{H})$, 12.80 (br s, $1 \mathrm{H}) .{ }^{13} \mathrm{C}$ NMR (75 MHz, DMSO-d6) $\delta 29.2,68.7,98$, 98.1, 105.2, 108.9 (d, $J=3.0 \mathrm{~Hz}), 109.4,113.1,115.6$ (d, $J=5.0$ $\mathrm{Hz}), 121.6,125.7$ ( $\mathrm{t}, J=36.7 \mathrm{~Hz}$ ), 126.8, 127.5, 139.5, 143.3, 158.7. HMRS (ESI) $\mathrm{m} / z$ Calcd for $(\mathrm{M}+\mathrm{H})^{+} \mathrm{C}_{16} \mathrm{H}_{10} \mathrm{~N}_{4} \mathrm{OBr}_{2} \mathrm{~F}_{3}$ : 490.9147. Found: 490.9153. IR $\left(\mathrm{cm}^{-1}\right): 3154,1638,1564,1314$, $1168,1131,1052$.

4,5-Dibromo- $N$-(3-(6-fluoroimidazo[1,2-a]pyridin-3-yl)prop-2yn-1-yl)-1 $H$-pyrrole-2-carboxamide (24f). Compound $24 \mathrm{f}$ was synthesized according to general procedure B using $15 \mathrm{a}(214 \mathrm{mg}$, $0.70 \mathrm{mmol})$ and $23 \mathrm{f}(122 \mathrm{mg}, 0.47 \mathrm{mmol})$. Purification afforded the title compound as a pale yellow amorphous solid $(129 \mathrm{mg}, 63$ \%). ${ }^{1} \mathrm{H}$ NMR (300MHz, DMSO-d6) $\delta 4.45(\mathrm{~d}, J=5.4 \mathrm{~Hz}, 2 \mathrm{H})$, $6.99(\mathrm{~s}, 1 \mathrm{H}), 7.49(\mathrm{t}, J=9.2 \mathrm{~Hz}, 1 \mathrm{H}), 7.77(\mathrm{dd}, J=5.1,9.3 \mathrm{~Hz}, 1 \mathrm{H})$, $7.94(\mathrm{~s}, 1 \mathrm{H}), 8.63(\mathrm{~s}, 1 \mathrm{H}), 8.74(\mathrm{t}, J=4.9 \mathrm{~Hz}, 1 \mathrm{H}), 12.82(\mathrm{~s}, 1 \mathrm{H})$. ${ }^{13} \mathrm{C}$ NMR (75 MHz, DMSO-d6) $\delta$ 29.3, 69.1, 98, 98.1, 105.2, $108.9,112.3$ (d, $J=41.6 \mathrm{~Hz},), 113.2,118.0$ (d, $J=25.7 \mathrm{~Hz}), 118.4$ (d, $J=9.3 \mathrm{~Hz}), 127.6,138.6,152-155.1$ (d, $J=235.8 \mathrm{~Hz}$ ), 158.7 . Some quaternary carbons and aromatic $\mathrm{CH}$ too broad to be seen due to very slow relaxation. HMRS (ESI) $\mathrm{m} / z$ Calcd for $(\mathrm{M}+\mathrm{H})^{+}$ $\mathrm{C}_{15} \mathrm{H}_{10} \mathrm{~N}_{4} \mathrm{OBr}_{2} \mathrm{~F}: 440.9188$. Found: 440.9185. IR $\left(\mathrm{cm}^{-1}\right): 3148$, 1653, 1562, 1519, 1499, 1404, 1309, 1221.

4,5-Dibromo- $N$-(3-(6-methylimidazo[1,2-a]pyridin-3-yl)prop-2yn-1-yl)-1 $H$-pyrrole-2-carboxamide $(\mathbf{2 4 g})$. Compound $\mathbf{2 4 g}$ was synthesized according to general procedure B using $15 \mathrm{a}(376 \mathrm{mg}$, $1.23 \mathrm{mmol}$ ) and $\mathbf{2 3 g}(211 \mathrm{mg}, 0.82 \mathrm{mmol})$. Purification afforded 
the title compound as a pale yellow amorphous solid (105 $\mathrm{mg}, 30$ \%). ${ }^{1} \mathrm{H}$ NMR $(300 \mathrm{MHz}, \mathrm{DMSO}-\mathrm{d} 6) \delta 2.34(\mathrm{~s}, 3 \mathrm{H}), 4.45$ (d, $J=$ $5.3 \mathrm{~Hz}, 2 \mathrm{H}), 7.0(\mathrm{~s}, 1 \mathrm{H}), 7.25(\mathrm{~d}, J=8.7 \mathrm{~Hz}, 1 \mathrm{H}), 7.59$ (d, $J=8.7$ $\mathrm{Hz}, 1 \mathrm{H}), 7.82(\mathrm{~s}, 1 \mathrm{H}), 8.25$ (s, $1 \mathrm{H}), 8.74(\mathrm{t}, J=5.2 \mathrm{~Hz}, 1 \mathrm{H}), 12.80$ (s, 1H). ${ }^{13} \mathrm{C}$ NMR $(75 \mathrm{MHz}$, DMSO-d6) $\delta 17.5,29.2,69.7,97.1$, 98, 105.2, 107.4, 113.1, 116.8, 122.7, 123.1, 127.6, 129.1, 137.5, 144.2, 158.7. HMRS (ESI) $\mathrm{m} / z$ Calcd for $(\mathrm{M}+\mathrm{H})^{+} \mathrm{C}_{16} \mathrm{H}_{13} \mathrm{~N}_{4} \mathrm{OBr}_{2}$ : 436.9436. Found: 436.9457. IR $\left(\mathrm{cm}^{-1}\right): 3144,1651,1564,1404$, $1308,1243,1162$.

4,5-Dibromo- $N$-(3-(7-methylimidazo[1,2-a]pyridin-3-yl)prop-2yn-1-yl)-1 $H$-pyrrole-2-carboxamide (24h). Compound $24 \mathrm{~h}$ was synthesized according to general procedure B using $15 \mathrm{a}(457 \mathrm{mg}$, $1.5 \mathrm{mmol})$ and $23 \mathrm{~h}(257 \mathrm{mg}, 1.0 \mathrm{mmol})$. Purification afforded the title compound as a beige amorphous solid $(100 \mathrm{mg}, 23 \%) .{ }^{1} \mathrm{H}$ NMR (300MHz, DMSO-d6) $\delta 2.39(\mathrm{~s}, 3 \mathrm{H}), 4.43(\mathrm{~d}, J=5.3 \mathrm{~Hz}$, $2 \mathrm{H}), 6.96(\mathrm{~d}, J=6.9 \mathrm{~Hz}, 1 \mathrm{H}), 6.99(\mathrm{~s}, 1 \mathrm{H}), 7.47$ (br s, $1 \mathrm{H}), 8.35$ (br s, $1 \mathrm{H}), 8.75(\mathrm{t}, J=5.4 \mathrm{~Hz}, 1 \mathrm{H}), 12.81(\mathrm{~s}, 1 \mathrm{H}) .{ }^{13} \mathrm{C} \mathrm{NMR}(75$ MHz, DMSO-d6) $\delta 20.7,29.2,69,97,97.9,105.1,113.1,115.8$, $116,124.5,127.6,136.9,158.7$. Some quaternary carbons and aromatic $\mathrm{CH}$ too broad to be seen due to very slow relaxation. HMRS (ESI) $\mathrm{m} / z$ Calcd for $(\mathrm{M}+\mathrm{H})^{+} \mathrm{C}_{16} \mathrm{H}_{13} \mathrm{~N}_{4} \mathrm{OBr}_{2}$ : 436.9436. Found: 436.9424. IR $\left(\mathrm{cm}^{-1}\right): 3136,1634,1566,1400,1244,1190$.

$N$-(3-(1H-pyrrolo[2,3-b]pyridin-3-yl)prop-2-yn-1-yl)-4,5-dibromo- $1 H$-pyrrole-2-carboxamide (29). Compound 29 was synthesized according to general procedure B using $15 \mathrm{a}(200 \mathrm{mg}, 0.65$ $\mathrm{mmol}$ ) and $27(301 \mathrm{mg}, 0.78 \mathrm{mmol})$. Purification afforded the intermediate 28 as a brown amorphous solid ( $221 \mathrm{mg}, 60 \%) .28$ (125 $\mathrm{mg}, 0.22 \mathrm{mmol}, 1.2$ eq.) was dissolved in $2 \mathrm{~mL}$ of dry THF. A solution of TBAF ( $187 \mathrm{mg}, 0.67 \mathrm{mmol}$, 3eq.) in $0.7 \mathrm{~mL}$ of dry THF was added to the mixture. It was stirred at room temperature for $3 \mathrm{~h}$ and then at $50^{\circ} \mathrm{C}$ for $2 \mathrm{~h}$ until completion of reaction. The solvent was removed under vacuum. The crude was purified by silica gel flash chromatography (elution by gradient from 100 to $90 / 10$ $\mathrm{DCM} / \mathrm{MeOH}$ ) to afford the deprotected compound 29 as a beige amorphous solid (57 mg, 61\%). ${ }^{1} \mathrm{H}$ NMR (300MHz, DMSO-d6) $\delta 4.33(\mathrm{~d}, J=5.4 \mathrm{~Hz}, 2 \mathrm{H}), 7.0(\mathrm{~s}, 1 \mathrm{H}), 7.16(\mathrm{dd}, J=4.5,7.9 \mathrm{~Hz}$, $1 \mathrm{H},), 7.78(\mathrm{~s}, 1 \mathrm{H}),, 7.94(\mathrm{~d}, J=7.9 \mathrm{~Hz}, 1 \mathrm{H}), 8.28(\mathrm{~d}, J=4.4 \mathrm{~Hz}$, $1 \mathrm{H}), 8.66(\mathrm{t}, J=5.5 \mathrm{~Hz}, 1 \mathrm{H}), 12.0(\mathrm{~s}, 1 \mathrm{H}), 12.76(\mathrm{~s}, 1 \mathrm{H}) .{ }^{13} \mathrm{C} \mathrm{NMR}$ (75 MHz, DMSO-d6) $\delta$ 29, 75.4, 87.5, 94.7, 97.9, 105, 112.9, 116.3, 120.3, 127.8, 127, 130.1, 143.8, 147.6, 158.5. HMRS (ESI) $\mathrm{m} / z$ Calcd for $(\mathrm{M}+\mathrm{H})^{+} \mathrm{C}_{15} \mathrm{H}_{11} \mathrm{~N}_{4} \mathrm{OBr}_{2}$ : 422.9279. Found: 422.9273. IR $\left(\mathrm{cm}^{-1}\right)$ : 3200, 1618, 1517, 1410, 1293, 1214.

$N$-(3-(8-acetamidoimidazo[1,2-a]pyridin-3-yl)prop-2-yn-1-yl)4,5-dibromo- $1 H$-pyrrole-2-carboxamide (35). Compound 35 was synthesized according to general procedure B using 15a (264 mg, $0.86 \mathrm{mmol}$ ) and $33 \mathrm{a}(200 \mathrm{mg}, 0.66 \mathrm{mmol})$. Purification afforded the title compound as a beige amorphous solid $110 \mathrm{mg}, 35 \%) .{ }^{1} \mathrm{H}$ NMR (300MHz, DMSO-d6) $\delta 2.21(\mathrm{~s}, 3 \mathrm{H}),, 4.44(\mathrm{~d}, J=5.5 \mathrm{~Hz}$, $2 \mathrm{H}), 6.99(\mathrm{~d}, J=2.7 \mathrm{~Hz}, 1 \mathrm{H}), 7.06(\mathrm{t}, J=7 \mathrm{~Hz}, 1 \mathrm{H}), 7.87(\mathrm{~s}, 1 \mathrm{H})$, $8.09(\mathrm{~d}, J=7.6 \mathrm{~Hz}, 1 \mathrm{H}), 8.16(\mathrm{dd}, J=1,7 \mathrm{~Hz}, 1 \mathrm{H}), 8.75(\mathrm{t}, J=$ $5.5 \mathrm{~Hz}, 1 \mathrm{H}), 10.1(\mathrm{~s}, 1 \mathrm{H}), 12.81(\mathrm{~s}, 1 \mathrm{H}) .{ }^{13} \mathrm{C} \mathrm{NMR}(75 \mathrm{MHz}$, DMSO-d6) $\delta 24,29.2,69.3,97.2,98,105.2,108.7,112.5,113.1$, 113.9, 119.6, 127.6, 127.9, 136.1, 138.8, 158.7, 169.9. HMRS (ESI) $\mathrm{m} / z$ Calcd for $(\mathrm{M}+\mathrm{H})^{+} \mathrm{C}_{17} \mathrm{H}_{14} \mathrm{~N}_{5} \mathrm{O}_{2} \mathrm{Br}_{2}$ : 479.9494. Found: 479.9506. IR $\left(\mathrm{cm}^{-1}\right): 3115,1636,1552,1522,1412,1276,1222$.

$N$-(3-(8-aminoimidazo[1,2-a]pyridin-3-yl)prop-2-yn-1-yl)-4,5dibromo- $1 H$-pyrrole-2-carboxamide (37). Compound 37 was synthesized according to general procedure B using 15a (466 mg, $1.52 \mathrm{mmol})$ and 33b $(350 \mathrm{mg}, 0.76 \mathrm{mmol})$. Purification afforded 36 as a brown amorphous solid ( $321 \mathrm{mg}, 66 \%)$. Then $36(320 \mathrm{mg}$,
$0.5 \mathrm{mmol}$, 1eq.) was dissolved in $2.5 \mathrm{~mL}$ of dry DCM under argon at $0^{\circ} \mathrm{C}$. TFA $(0.37 \mathrm{~mL}, 5 \mathrm{mmol}, 10$ eq. $)$ was added dropwise to the reaction mixture. After $2 \mathrm{~h}, 10$ eq. of TFA $(0.37 \mathrm{~mL})$ were again added to the mixture at $-5^{\circ} \mathrm{C}$. The reaction mixture was stirred at $5^{\circ} \mathrm{C} 2 \mathrm{~h}$ and then $2 \mathrm{~h}$ at room temperature. The mixture was quenched with an aqueous solution of $\mathrm{Na}_{2} \mathrm{CO}_{3}$ and extracted with DCM. Collected organic layers were dried over MgSO4, filtered and concentrated under vacuum. Flash chromatographic purification (elution by gradient from 100 to $95 / 5 \mathrm{DCM} / \mathrm{MeOH}$ ) afforded compound 37 as a beige amorphous solid (153 mg, $70 \%$ ). ${ }^{1} \mathrm{H}$ NMR (300MHz, DMSO-d6) $\delta 4.42$ (d, $\left.J=6.6 \mathrm{~Hz}, 2 \mathrm{H}\right), 5.79$ $(\mathrm{s}, 2 \mathrm{H}), 6.37(\mathrm{dd}, J=1.0,7.5 \mathrm{~Hz}, 1 \mathrm{H}), 6.83(\mathrm{t}, J=6.9 \mathrm{~Hz}, 1 \mathrm{H})$, $6.99(\mathrm{~s}, 1 \mathrm{H}), 7.7(\mathrm{~m}, 2 \mathrm{H}), 8.74(\mathrm{t}, J=5.4 \mathrm{~Hz}, 1 \mathrm{H}), 12.8(\mathrm{~s}, 1 \mathrm{H}) .{ }^{13} \mathrm{C}$ NMR (75 MHz, DMSO-d6) $\delta 29.2,70.1,96.5,98,101.9,105.2$, $108,112.7,113.1,114.9,127.6,135.6,137.6,138.9,158.7$. HMRS (ESI) $\mathrm{m} / z$ Calcd for $(\mathrm{M}+\mathrm{H})^{+} \mathrm{C}_{15} \mathrm{H}_{12} \mathrm{~N}_{5} \mathrm{OBr}_{2}$ : 437.9388. Found: 437.9375. IR $\left(\mathrm{cm}^{-1}\right): 3376,3133,1645,1557,1402,1240$.

$N$-(3-(6-aminoimidazo[1,2-a]pyridin-3-yl)prop-2-yn-1-yl)-4,5dibromo-1 $H$-pyrrole-2-carboxamide (38). Compound 38 was synthesized according to general procedure B using $15 \mathrm{a}$ and $33 \mathrm{c}$ (358 $\mathrm{mg}, 0.78 \mathrm{mmol}$ ). The protected intermediate was directly engaged in a TFA $(1 \mathrm{~mL})$ deprotection in $\mathrm{DCM}$ at $0^{\circ} \mathrm{C}$ then at room temperature. After $24 \mathrm{~h}$ of reaction, the reaction mixture was quenched with $\mathrm{Na}_{2} \mathrm{CO}_{3}$ and concentrated under vacuum. The crude product was purified by silica gel flash chromatography (elution by gradient from 100 to $95 / 5 \mathrm{DCM} / \mathrm{MeOH}$ ) to afford a brown amorphous solid ( $38 \mathrm{mg}, 11 \%$ over two steps). ${ }^{1} \mathrm{H}$ NMR $(500 \mathrm{MHz}, \mathrm{DMF}-\mathrm{d} 7) \delta 4.53(\mathrm{~s}, 2 \mathrm{H}), 5,26(\mathrm{~s}, 2 \mathrm{H}), 7.10(\mathrm{~d}, J=$ $9.5 \mathrm{~Hz}, 1 \mathrm{H}), 7.14(\mathrm{~s}, 1 \mathrm{H}), 7.44(\mathrm{~d}, J=9.2 \mathrm{~Hz}, 1 \mathrm{H}), 7.66(\mathrm{~s}, 1 \mathrm{H})$, $7.86(\mathrm{~s}, 1 \mathrm{H}), 8.81(\mathrm{t}, J=4.6 \mathrm{~Hz}, 1 \mathrm{H}), 12.95(\mathrm{~s}, 1 \mathrm{H}) .{ }^{13} \mathrm{C} \mathrm{NMR}(75$ MHz, DMF-d7) $\delta 29.8,70.8,96.7,98.7,105.3,106.6$ (two carbons), 113.6, 117.4, 21.6, 128.7, 137, 138.2, 142.2, 159.2. HMRS (ESI) $\mathrm{m} / z$ Calcd for $(\mathrm{M}+\mathrm{H})^{+} \mathrm{C}_{15} \mathrm{H}_{12} \mathrm{~N}_{5} \mathrm{OBr}_{2}$ : 437.9388. Found: 437.9388. IR $\left(\mathrm{cm}^{-1}\right): 3149,2920,2849,1628,1565,1521,1500$, 1414, 1203.

$N$-(3-(8-amino-6-bromoimidazo[1,2-a]pyridin-3-yl)prop-2-yn-1yl)-4,5-dibromo-1H-pyrrole-2-carboxamide (43). Compound 43 was synthesized according to general procedure B using 15 a (238 $\mathrm{mg}, 0.78 \mathrm{mmol})$ and $33 \mathrm{~d}(209 \mathrm{mg}, 0.39 \mathrm{mmol})$ to afford the protected intermediate, which was dissolved in $2 \mathrm{~mL}$ of DCM. The mixture was cooled with an ice bath and TFA was added $(0.2 \mathrm{~mL}$, 10 eq.). The mixture was stirred $8 \mathrm{~h}$ at room temperature. The reaction was quenched with the addition of $\mathrm{NaOH} 10 \%$, the resulting precipitate was filtered and rinsed with water and then DCM yielding a beige amorphous solid 43 (119 $\mathrm{mg}, 59 \%$ over two steps). ${ }^{1} \mathrm{H}$ NMR (300MHz, DMSO-d6) $\delta 4.43$ (d, $\left.J=5.6 \mathrm{~Hz}, 2 \mathrm{H}\right), 6.18$ (br s, $2 \mathrm{H}), 6.48$ (d, $J=1.7 \mathrm{~Hz}, 1 \mathrm{H}), 6.99$ (d, $J=2.8 \mathrm{~Hz}, 1 \mathrm{H}), 7.73$ $(\mathrm{s}, 1 \mathrm{H}), 7.83(\mathrm{~d}, J=1.6 \mathrm{~Hz}, 1 \mathrm{H}), 8.72(\mathrm{t}, J=5.5 \mathrm{~Hz}, 1 \mathrm{H}), 12.80(\mathrm{~s}$, $1 \mathrm{H}) .{ }^{13} \mathrm{C}$ NMR (75 MHz, DMSO-d6) $\delta 29.2,69.3,97.3,98,104.6$, 105.2, 108.6, 109.5, 112, 113.1, 127.6, 135.5, 137.1, 138.2, 158.7 . HMRS (ESI) $m / z$ Calcd for $(\mathrm{M}+\mathrm{H})^{+} \mathrm{C}_{15} \mathrm{H}_{11} \mathrm{~N}_{5} \mathrm{OBr}_{3}$ : 515.8493 . Found: 515.8485. IR $\left(\mathrm{cm}^{-1}\right): 3385,3147,1649,1600,1561,1397$, $1239,1212$.

$N$-(3-(8-aminoimidazo[1,2-a]pyridin-3-yl)prop-2-yn-1-yl)-4,5dichloro- $1 H$-pyrrole-2-carboxamide (44). Compound 44 was synthesized according to general procedure B using $15 \mathrm{~b}$ ( $150 \mathrm{mg}, 0.69$ $\mathrm{mmol})$ and $33 \mathrm{~b}(317 \mathrm{mg}, 0.69 \mathrm{mmol})$. Then the intermediate was dissolved in $2 \mathrm{~mL}$ of dry DCM under argon at $0^{\circ} \mathrm{C}$. TFA $(0.63 \mathrm{~mL}$, 17 eq.) was added dropwise to the reaction mixture. After $2 \mathrm{~h}$ of reaction, 10 eq. of TFA $(0.37 \mathrm{~mL})$ were added to the mixture at 
$0^{\circ} \mathrm{C}$. The reaction mixture was stirred at room temperature $7 \mathrm{~h}$. The mixture was quenched with an aqueous solution of $\mathrm{NaHCO}_{3}$ and extracted with DCM. Collected organic layers were dried over $\mathrm{MgSO}_{4}$, filtered and concentrated under vacuum. Flash chromatographic purification (elution by gradient from 100 to $95 / 5$ $\mathrm{DCM} / \mathrm{MeOH}$ ) afforded compound 44 as a beige amorphous solid (60 mg, $25 \%$ over two steps). ${ }^{1} \mathrm{H}$ NMR (300MHz, DMSO-d6) $\delta$ $4.43(\mathrm{~d}, J=5.4 \mathrm{~Hz}, 2 \mathrm{H}), 5.78(\mathrm{br} \mathrm{s}, 2 \mathrm{H}), 6.38(\mathrm{dd}, J=0.9,7.6 \mathrm{~Hz}$, $1 \mathrm{H}), 6.83(\mathrm{t}, J=6.9 \mathrm{~Hz}, 1 \mathrm{H}), 6.96(\mathrm{~s}, 1 \mathrm{H}, \mathrm{H} 4), 7.70(\mathrm{~d}, J=6.9 \mathrm{~Hz}$, $1 \mathrm{H}), 7.71(\mathrm{~s}, 1 \mathrm{H}), 8.76(\mathrm{t}, J=5.4 \mathrm{~Hz}, 1 \mathrm{H}), 12.84(\mathrm{br} \mathrm{s}, 1 \mathrm{H}) \cdot{ }^{13} \mathrm{C}$ NMR (75 MHz, DMSO-d6) $\delta 29.2,70.1,96.5,101.9,108,108.1$, 110.1 , 112.7, 114.9, 115.4, 124.3, 135.6, 137.5, 138.9, 158.8 . HMRS (ESI) $\mathrm{m} / z$ Calcd for $(\mathrm{M}+\mathrm{H})^{+} \mathrm{C}_{15} \mathrm{H}_{12} \mathrm{Cl}_{2} \mathrm{~N}_{5} \mathrm{O}: 348.0419$. Found: 348.0457. IR $\left(\mathrm{cm}^{-1}\right): 3149,1651,1607,1514,1493,1431$.

$N$-(3-(8-aminoimidazo[1,2-a]pyridin-3-yl)prop-2-yn-1-yl)-4,5diiodo- $1 H$-pyrrole-2-carboxamide (45). Compound 45 was synthesized according to general procedure B using $15 \mathrm{c}$ ( $180 \mathrm{mg}, 0.45$ $\mathrm{mmol})$ and 33b $(207 \mathrm{mg}, 0.45 \mathrm{mmol})$. Then the intermediate was dissolved in $2 \mathrm{~mL}$ of dry DCM under argon at $0^{\circ} \mathrm{C}$. TFA $(0.67 \mathrm{~mL}$, 20 eq.) was added dropwise to the reaction mixture. After $2 \mathrm{~h}$ of reaction, 10 eq. of TFA $(0.37 \mathrm{~mL})$ were added to the mixture at $0^{\circ} \mathrm{C}$. The reaction mixture was stirred $5 \mathrm{~h}$ at room temperature. The mixture was quenched with an aqueous solution of $\mathrm{Na}_{2} \mathrm{CO}_{3}$ and extracted with EtOAc. Collected organic layers were dried over $\mathrm{MgSO}_{4}$, filtered and concentrated under vacuum. Flash chromatographic purification (elution by gradient from 100 to $90 / 10$ $\mathrm{DCM} / \mathrm{MeOH}$ ) afforded compound 45 as a beige amorphous solid (97 mg, $41 \%$ over two steps). ${ }^{1} \mathrm{H}$ NMR (300MHz, DMSO-d6) $\delta$ $4.41(\mathrm{~d}, J=5.3 \mathrm{~Hz}, 2 \mathrm{H}), 5.78(\mathrm{br} \mathrm{s}, 2 \mathrm{H}), 6.38(\mathrm{~d}, J=7.4 \mathrm{~Hz}, 1 \mathrm{H})$, $6.82(\mathrm{t}, J=7.4 \mathrm{~Hz}, 1 \mathrm{H}), 6.97(\mathrm{~d}, J=2.2 \mathrm{~Hz}, 1 \mathrm{H}), 7.69(\mathrm{~d}, J=5.7 \mathrm{~Hz}$, $1 \mathrm{H}), 7.71(\mathrm{~s}, 1 \mathrm{H}), 8.65(\mathrm{t}, J=5.2 \mathrm{~Hz}, 1 \mathrm{H}), 12.42(\mathrm{~s}, 1 \mathrm{H}) \cdot{ }^{13} \mathrm{C} \mathrm{NMR}$ (75 MHz, DMSO-d6) $\delta$ 29.2, 70, 76.2, 84.1, 96.6, 101.9, 108.2, $112.7,114.9,118.6,132.2,135.5,137.5,139,158.4$. HMRS (ESI) $m / z$ Calcd for $(\mathrm{M}+\mathrm{H})^{+} \mathrm{C}_{15} \mathrm{H}_{12} \mathrm{I}_{2} \mathrm{~N}_{5} \mathrm{O}: 531.9131$. Found: 531.9142 . IR $\left(\mathrm{cm}^{-1}\right): 3126,1628,1552,1494,1375,1288$.

4,5-Dibromo- $N$-(3-(6-morpholinoimidazo[1,2-a]pyridin-3yl)prop-2-yn-1-yl)-1 $H$-pyrrole-2-carboxamide (48). Compound 48 was synthesized according to general procedure B using 15a (383mg, $1.3 \mathrm{mmol})$ and $46(206 \mathrm{mg}, 0.63 \mathrm{mmol})$. Purification afforded the title compound as a beige amorphous solid (71mg, 22 \%). ${ }^{1} \mathrm{H}$ NMR (300MHz, DMSO-d6) $\delta 3.05(\mathrm{t}, J=4.5 \mathrm{~Hz}, 4 \mathrm{H})$, $3.75(\mathrm{t}, J=4.5 \mathrm{~Hz}, 4 \mathrm{H}), 4.43(\mathrm{~d}, J=5.3 \mathrm{~Hz}, 2 \mathrm{H}), 6.99(\mathrm{~s}, 1 \mathrm{H}), 7.38$ $(\mathrm{d}, J=9.9 \mathrm{~Hz}, 1 \mathrm{H}), 7.57(\mathrm{~d}, J=9.9 \mathrm{~Hz}, 1 \mathrm{H}), 7.64(\mathrm{~s}, 1 \mathrm{H}),, 7.76(\mathrm{~s}$, $1 \mathrm{H}), 8.79(\mathrm{t}, J=5.3 \mathrm{~Hz}, 1 \mathrm{H}), 12.79(\mathrm{~s}, 1 \mathrm{H}) .{ }^{13} \mathrm{C} \mathrm{NMR}(75 \mathrm{MHz}$, DMSO-d6) $\delta 49.3,65.8,29.3,69.9,97.5,98,105.1,107.8,108.8$, $113,117.2,121.7,127.6,136.9,140.5,141.7,158.7$. HMRS (ESI) $\mathrm{m} / z$ Calcd for $(\mathrm{M}+\mathrm{H})^{+} \mathrm{C}_{19} \mathrm{H}_{18} \mathrm{~N}_{5} \mathrm{O}_{2} \mathrm{Br}_{2}$ : 507.9807. Found: 507.9807. IR $\left(\mathrm{cm}^{-1}\right): 3111,1642,1567,1505,1402,1244,1167$, 1118.

4,5-Dibromo- $N$-(3-(6-(piperazin-1-yl)imidazo[1,2-a]pyridin-3yl)prop-2-yn-1-yl)-1 $H$-pyrrole-2-carboxamide (50). Compound 50 was synthesized according to general procedure B using 15a (296 mg, $0.97 \mathrm{mmol}$ ) and 47 (207 mg, $0.48 \mathrm{mmol})$. Purification afforded 49 as a yellow amorphous solid. Compound 49 was further dissolved in $4 \mathrm{~mL}$ of DCM and cooled with an ice bath and then $\mathrm{HCl}$ ( $4 \mathrm{~N}$ dioxane) was added $(0.6 \mathrm{~mL})$ with $2 \mathrm{~mL}$ of methanol. The reaction mixture was stirred overnight at room temprature. The solvent was removed under vacuum, the resulting solid rinsed with DCM and $\mathrm{MeOH}$ to afford the salt $\mathbf{5 0}$ a white amorphous solid (123 mg, 44\% over two steps). ${ }^{1} \mathrm{H}$ NMR (300MHz,
DMSO-d6) $\delta 3.27(\mathrm{~s}, 4 \mathrm{H}), 3.54(\mathrm{~s}, 4 \mathrm{H}), 4.45(\mathrm{~d}, J=5.3 \mathrm{~Hz}, 2 \mathrm{H})$, $7.08(\mathrm{~d}, J=2.7 \mathrm{~Hz}, 1 \mathrm{H}), 7.92(\mathrm{~m}, 2 \mathrm{H}), 8.03(\mathrm{~s}, 1 \mathrm{H}), 8.41(\mathrm{~s}, 1 \mathrm{H})$, $9.28(\mathrm{t}, J=5.2 \mathrm{~Hz}, 1 \mathrm{H}), 9.64(\mathrm{br} \mathrm{s}, 2 \mathrm{H}), 12.91(\mathrm{~s}, 1 \mathrm{H}) .{ }^{13} \mathrm{C} \mathrm{NMR}$ $(75 \mathrm{MHz}, \mathrm{DMSO}-\mathrm{d} 6) \delta 29.2$, 42.2, 45.5, 66.7, 98.1, 99.5, 105, 109.3, 113.3, 113.8, 127.2, 127.6, 127.7, 135.6, 142.1, 158.7 . HMRS (ESI) $m / z$ Calcd for $(\mathrm{M}+\mathrm{H})^{+} \mathrm{C}_{19} \mathrm{H}_{19} \mathrm{~N}_{6} \mathrm{OBr}_{2}$ : 506.9967. Found: 506.9964. IR $\left(\mathrm{cm}^{-1}\right): 3275,2928,1640,1521,1390,1322$, 1237.

General Procedure C for Amidation (55-57).

Boc-protected amine 52-54 (1 eq.) was dissolved in 2-6 mL of concentrated $\mathrm{HCl}$ under argon at room temperature. The reaction mixture was stirred 3-5 h until completion of reaction. The solvent was removed under vacuum. The residue was taken up with DMF and $\mathrm{NaHCO}_{3}$ to form the free base. 14a (1eq.) was added and the mixture was stirred overnight at room temperature. It was concentrated under vacuum and the product was purified by silica gel flash chromatography (elution by gradient from 100 to $95 / 5$ $\mathrm{DCM} / \mathrm{MeOH})$ to yield the desired alkene.

(E)-4,5-Dibromo- $N$-(3-(imidazo[1,2-a]pyrimidin-3-yl)allyl)-

$1 H$-pyrrole-2-carboxamide (55). Compound 55 was synthesized according to general procedure $C$ using $14 \mathrm{a}(108 \mathrm{mg}, 0.29 \mathrm{mmol})$ and $52(80 \mathrm{mg}, 0.29 \mathrm{mmol})$. Purification afforded the title compound as a yellow amorphous solid (52 mg, $42 \%) .{ }^{1} \mathrm{H}$ NMR (300MHz, DMSO-d6) $\delta 4.1(\mathrm{t}, J=5.7 \mathrm{~Hz}, 1 \mathrm{H}), 6.38(\mathrm{dt}, J=5.7$, $16.1 \mathrm{~Hz}, 1 \mathrm{H}), 6.89$ (d, $J=16.1 \mathrm{~Hz}, 1 \mathrm{H}), 7(\mathrm{~s}, 1 \mathrm{H}), 7.12(\mathrm{dd}, J=$ $4.4,7 \mathrm{~Hz}, 1 \mathrm{H}), 8.01(\mathrm{~s}, 1 \mathrm{H}), 8.42(\mathrm{t}, J=5.7 \mathrm{~Hz}, 1 \mathrm{H}), 8.52(\mathrm{dd}, J=$ $1.9,4.1 \mathrm{~Hz}, 1 \mathrm{H}), 9.03(\mathrm{dd}, J=1.9,7.1 \mathrm{~Hz}, 1 \mathrm{H}), 12.7(\mathrm{~s}, 1 \mathrm{H}) .{ }^{13} \mathrm{C}$ NMR (75 MHz, DMSO-d6) $\delta 40.8,97.8,104.6,109,112.8,115.6$, 121.5, 127.3, 128.1, 132.4, 138.8, 148, 149.4, 158.7. HMRS (ESI) $\mathrm{m} / z$ Calcd for $(\mathrm{M}+\mathrm{H})^{+} \mathrm{C}_{14} \mathrm{H}_{12} \mathrm{~N}_{5} \mathrm{O}_{2} \mathrm{Br}_{2}$ : 425.9388. Found: 425.9388. IR $\left(\mathrm{cm}^{-1}\right): 3102,3048,1619,1562,1511,1243,1151$.

(E)-4,5-dibromo- $N$-(3-(imidazo[1,2-a]pyrazin-3-yl)allyl)- $1 H$ pyrrole-2-carboxamide (56). Compound 56 was synthesized according to general procedure $C$ using $14 \mathrm{a}(97 \mathrm{mg}, 0.26 \mathrm{mmol})$ and $53(72 \mathrm{mg}, 0.26 \mathrm{mmol})$. Purification afforded the title compound as a beige amorphous solid ( $57 \mathrm{mg}, 51 \%) .{ }^{1} \mathrm{H}$ NMR $(300 \mathrm{MHz}$, DMSO-d6) $\delta 4.20(\mathrm{t}, J=5.9 \mathrm{~Hz}, 1 \mathrm{H}), 6.59(\mathrm{dt}, J=6,16.1 \mathrm{~Hz}, 1 \mathrm{H})$, $7.06(\mathrm{~d}, J=16.1 \mathrm{~Hz}, 1 \mathrm{H}), 7.12(\mathrm{~s}, 1 \mathrm{H}), 7.97(\mathrm{~d}, J=4.6 \mathrm{~Hz}, 1 \mathrm{H})$, $8.14(\mathrm{~s}, 1 \mathrm{H}), 8.45(\mathrm{t}, J=5.9 \mathrm{~Hz}, 1 \mathrm{H}), 8.7(\mathrm{~d}, J=5 \mathrm{~Hz}, 1 \mathrm{H}), 9.04$ $(\mathrm{s}, 1), 12.86(\mathrm{~s}, 1 \mathrm{H}) \cdot{ }^{13} \mathrm{C}$ NMR $(75 \mathrm{MHz}$, DMSO-d6) $\delta 41.1,98.6$, $104.9,113.1,115.7,117.9,125.3,129.6,129.1,130.1,133.7,141.2$, 143.6, 159.3. HMRS (ESI) $\mathrm{m} / \mathrm{z}$ Calcd for $(\mathrm{M}+\mathrm{H})^{+}$ $\mathrm{C}_{14} \mathrm{H}_{12} \mathrm{~N}_{5} \mathrm{O}_{2} \mathrm{Br}_{2}$ : 425.9388. Found: 425.9401. IR $\left(\mathrm{cm}^{-1}\right)$ : 3377, 2647, 1624, 1511, 1487, 1410, 1313, 1161.

(E)-4,5-dibromo- $N$-(3-(imidazo[1,2-b]pyridazin-3-yl)allyl)- $1 H$ pyrrole-2-carboxamide (57). Compound 57 was synthesized according to general procedure $\mathrm{C}$ using $14 \mathrm{a}(332 \mathrm{mg}, 0.9 \mathrm{mmol})$ and 54 (224 mg, $0.82 \mathrm{mmol}$ ). Purification afforded the title compound as a beige amorphous solid (125 mg, $40 \%)$. ${ }^{1} \mathrm{H}$ NMR $(300 \mathrm{MHz}$, DMSO-d6) $\delta 4.10(\mathrm{t}, J=4.8 \mathrm{~Hz}, 1 \mathrm{H}), 6.82(\mathrm{~m}, 2 \mathrm{H}), 7.0(\mathrm{~s}, 1 \mathrm{H})$, $7.23(\mathrm{dd}, J=4.6,9.2 \mathrm{~Hz}, 1 \mathrm{H}), 8.0(\mathrm{~s}, 1 \mathrm{H}), 8.13(\mathrm{dd}, J=1.6,9.2 \mathrm{~Hz}$, $1 \mathrm{H}), 8.49(\mathrm{t}, J=5.6 \mathrm{~Hz}, 1 \mathrm{H}), 8.58(\mathrm{dd}, J=1.5,4.5 \mathrm{~Hz}, 1 \mathrm{H})$, 12.73(s, 1H). ${ }^{13} \mathrm{C}$ NMR (75 MHz, DMSO-d6) $\delta 40.6,97.9,104.7$, 112.7, 115.5, 116.9, 125.7, 125.8, 127.8, 128, 132.7, 139.3, 143.9, 158.7. HMRS (ESI) $m / z$ Calcd for $(\mathrm{M}+\mathrm{H})^{+} \mathrm{C}_{14} \mathrm{H}_{12} \mathrm{~N}_{5} \mathrm{O}_{2} \mathrm{Br}_{2}$ : 425.9388. Found: 425.9386. IR $\left(\mathrm{cm}^{-1}\right): 3107,3065,1644,1565$, 1522, 1317, 1239, 1151.

4,5-Dibromo- $N$-(3-(imidazo[1,2-a]pyrimidin-2-yl)phenyl)- $1 H$ pyrrole-2-carboxamide (63). 61 (50 mg, $0.24 \mathrm{mmol}, 1$ eq.) was 
dissolved in $1 \mathrm{~mL}$ of $\mathrm{Et}_{3} \mathrm{~N}$ under argon. 14a $(114 \mathrm{mg}, 0.31 \mathrm{mmol}$, 1.3 eq.) was added to the mixture. The reaction mixture was stirred at $60^{\circ} \mathrm{C}$ overnight. The solvent was removed under vacuum and the product was purified by silica gel flash chromatography (elution by gradient from 100 to $98 / 2 \mathrm{DCM} / \mathrm{MeOH}$ ) to yield 63 as a yellow amorphous solid (54 mg, $49 \%$ ). ${ }^{1} \mathrm{H}$ NMR (300MHz, DMSO-d6) $\delta 7.07(\mathrm{dd}, J=4.1,6.9 \mathrm{~Hz}, 1 \mathrm{H}), 7.30(\mathrm{~d}, J=2.7 \mathrm{~Hz}, 1 \mathrm{H}), 7.43(\mathrm{t}, J$ $=7.7 \mathrm{~Hz}, 1 \mathrm{H}), 7.69(\mathrm{dt}, J=1.1,8.2 \mathrm{~Hz}, 1 \mathrm{H}), 7.83(\mathrm{~d}, J=8.1 \mathrm{~Hz}$, $1 \mathrm{H}), 8.33(\mathrm{~s}, 1 \mathrm{H}), 8.35(\mathrm{t}, J=1.8 \mathrm{~Hz}, 1 \mathrm{H}), 8.54$ (dd, $J=2.1,4.1$ $\mathrm{Hz}, 1 \mathrm{H}), 8.98(\mathrm{dd}, J=2.1,6.7 \mathrm{~Hz}, 1 \mathrm{H}), 9.99(\mathrm{~s}, 1 \mathrm{H}), 12.91(\mathrm{~s}, 1 \mathrm{H})$. ${ }^{13} \mathrm{C}$ NMR (75 MHz, DMSO-d6) $\delta 98.2,105.9,107.5,108.9,113.9$, 117.3, 119.7, 120.8, 127.9, 129.2, 133.9, 135.1, 139.4, 145.1, 148, 150.4, 157.4. HMRS (ESI) $\mathrm{m} / z$ Calcd for $(\mathrm{M}+\mathrm{H})^{+} \mathrm{C}_{17} \mathrm{H}_{12} \mathrm{~N}_{5} \mathrm{OBr}_{2}$ : 461.9388. Found: 461.9412. IR $\left(\mathrm{cm}^{-1}\right): 3149,1610,1558,1400$, $1223,1198$.

4,5-Dibromo- $N$-(3-(imidazo[1,2-b] pyridazin-2-yl)phenyl)- $1 H$ pyrrole-2-carboxamide (64). 4,5-Dibromo-1H-pyrrole-2-carboxylic acid (100 mg, $0.37 \mathrm{mmol}, 1$ eq.) was dissolved in $1 \mathrm{~mL}$ of anhydrous DCM and a few drops of DMF under argon atmosphere. $(\mathrm{COCl})_{2}(130 \mu \mathrm{L}, 1.49 \mathrm{mmol}$, 4eq. $)$ was added to the mixture. The mixture was stirred overnight. The solvent was removed under vacuum and $1 \mathrm{~mL}$ of pyridine and $2 \mathrm{~mL}$ of DCM were added followed by 62 ( $86 \mathrm{mg}, 0.41 \mathrm{mmol}, 1.1 \mathrm{eq}$.). It was stirred at room temperature for $6 \mathrm{~h}$. The reaction mixture was concentrated with toluene and purified by silica gel flash chromatography (elution by gradient from 100 to $90 / 10 / \mathrm{MeOH}$ ) to afford 64 as a beige amorphous solid (77mg, 72\%). ${ }^{1} \mathrm{H}$ NMR (300MHz, DMSO-d6) $\delta 7.24$ (dd, $J$ $=4.5,9.2 \mathrm{~Hz}, 1 \mathrm{H}), 7.3(\mathrm{~d}, J=2.2 \mathrm{~Hz}, 1 \mathrm{H}), 7.42(\mathrm{t}, J=7.8 \mathrm{~Hz}, 1 \mathrm{H})$, $7.74(\mathrm{~d}, J=7.9 \mathrm{~Hz}, 1 \mathrm{H}), 7.81(\mathrm{~d}, J=7.9 \mathrm{~Hz}, 1 \mathrm{H}), 8.13(\mathrm{~d}, J=9.4 \mathrm{~Hz}$, $1 \mathrm{H}), 8.40(\mathrm{~s}, 1 \mathrm{H}), 8.50(\mathrm{dd}, J=1.5,4.4 \mathrm{~Hz}, 1 \mathrm{H}), 8.78(\mathrm{~s}, 1 \mathrm{H}), 9.98$ (br s, $1 \mathrm{H}), 12.9$ (br s, $1 \mathrm{H}) .{ }^{13} \mathrm{C}$ NMR $(75 \mathrm{MHz}, \mathrm{DMSO}-\mathrm{d} 6) \delta 98.2$, 105.9, 113.1, 113.9, 117.2, 117.8, 119.7, 121, 125, 127.9, 129.1, 133.8, 138.9, 139.3, 143.9, 144.4, 157.3. HMRS (ESI) $\mathrm{m} / z$ Calcd for $(\mathrm{M}+\mathrm{H})^{+} \mathrm{C}_{17} \mathrm{H}_{12} \mathrm{~N}_{5} \mathrm{OBr}_{2}$ : 461.9388. Found: 461.9420. IR $\left(\mathrm{cm}^{-1}\right): 3142,1646,1559,1426,1338,1236$.

General Procedure $\mathrm{D}$ for Amidation with $\mathrm{T}_{3} \mathrm{P}$.

4,5-dibromo-1H-pyrrole-2-carboxylic acid (1eq.) was dissolved in EtOAc and pyidine (3eq.). $\mathrm{T}_{3} \mathrm{P}$ (1.5eq.) was added to the mixture. After $10 \mathrm{~min}$, the corresponding aniline (1.1eq.) was added with a few drops of DMF to have a homogeneous mixture. The reaction mixture was stirred at room temperature overnight.

The solvent was removed under vacuum and the productand purified by silica gel flash chromatography (elution by gradient from 100 to $90 / 10 / \mathrm{MeOH})$ to afford the desired product.

4,5-Dibromo- $N$-(3-(imidazo[1,2-a]pyrazin-3-yl)phenyl)-1 $H$-pyrrole-2-carboxamide $(67 a)$. The title compound was synthesized according to general procedure $\mathrm{D}$ using $65 \mathrm{a}(43 \mathrm{mg}, 0.20 \mathrm{mmol})$ yielding $67 \mathrm{a}$ as a beige amorphous solid ( $55 \mathrm{mg}, 64 \%) .{ }^{1} \mathrm{H} \mathrm{NMR}$ $(300 \mathrm{MHz}, \mathrm{DMSO}-\mathrm{d} 6) \delta 6.92(\mathrm{br} \mathrm{s}, 1 \mathrm{H}), 7.36(\mathrm{~d}, J=7.6 \mathrm{~Hz}, 1 \mathrm{H})$, $7.5(\mathrm{t}, J=7.6 \mathrm{~Hz}, 1 \mathrm{H}), 7.88(\mathrm{~d}, J=7.6 \mathrm{~Hz}, 1 \mathrm{H}), 7.97(\mathrm{~d}, J=4.7 \mathrm{~Hz}$, $1 \mathrm{H}), 8.06(\mathrm{~s}, 1 \mathrm{H}), 8.12(\mathrm{t}, J=1.9 \mathrm{~Hz}, 1 \mathrm{H}), 8.67(\mathrm{dd}, J=1.4,4.8 \mathrm{~Hz}$, $1 \mathrm{H}), 9.15$ (s, 1H), 9.77 (s, 1H), 13.05 (br s, 1H). ${ }^{13} \mathrm{C}$ NMR $(75$ MHz,DMSO-d6) $\delta 113.7,117.5,117.8,119.3,121.6,126.4,127.8$, $129.7,129.8,134.4,140.4,140.9,143.7,159.8$. Some quaternary carbons and aromatic $\mathrm{CH}$ too broad to be seen due to very slow relaxation. HMRS (ESI) $\mathrm{m} / z$ Calcd for $(\mathrm{M}+\mathrm{H})^{+} \mathrm{C}_{17} \mathrm{H}_{12} \mathrm{~N}_{5} \mathrm{OBr}_{2}$ : 461.9388. Found: 461.9385. IR $\left(\mathrm{cm}^{-1}\right): 2974,1671,1595,1522$, 1418, 1305.
4,5-Dibromo- $N$-(3-(imidazo[1,2- $b]$ pyridazin-3-yl)phenyl)- $1 H$ pyrrole-2-carboxamide (67b). The title compound was synthesized according to general procedure D using $65 \mathrm{~b}(86 \mathrm{mg}, 0.41$ $\mathrm{mmol}$ ) yielding $67 \mathrm{~b}$ as a beige amorphous solid $(45 \mathrm{mg}, 26 \%) .{ }^{1} \mathrm{H}$ NMR (300MHz, DMSO-d6) $\delta 7.31(\mathrm{~m}, 1 \mathrm{H}), 7.34(\mathrm{~s}, 1 \mathrm{H}), 7.48(\mathrm{t}$, $J=8.0 \mathrm{~Hz}, 1 \mathrm{H}), 7.80$ (br s, $1 \mathrm{H}), 7.83$ (br s, $1 \mathrm{H}), 8.21$ (m, $1 \mathrm{H}), 8.23$ $(\mathrm{m}, 1 \mathrm{H}), 8.55(\mathrm{~s}, 1 \mathrm{H}), 8.65(\mathrm{~d}, J=4.1 \mathrm{~Hz}, 1 \mathrm{H}), 10.25(\mathrm{~s}, 1 \mathrm{H}), 13.07$ (s, 1H). ${ }^{13} \mathrm{C}$ NMR (75 MHz, DMSO-d6) $\delta 98.2,105.8,114.4$, $127.9,117.2$, 117.9, 119.6, 121.7, 126.1, 127.3, 128.8, 129, 132.8, 139.2, 140.2, 143.9, 157.4. HMRS (ESI) $\mathrm{m} / z$ Calcd for $(\mathrm{M}+\mathrm{H})^{+}$ $\mathrm{C}_{17} \mathrm{H}_{12} \mathrm{~N}_{5} \mathrm{OBr}_{2}$ : 461.9388. Found: 461.9383. IR $\left(\mathrm{cm}^{-1}\right)$ : 3157, 1665, 1562, 1433, 1291, 1233.

4,5-Dibromo- $N$-(3-(imidazo[1,2-a]pyridin-3-yl)phenyl)-1 $H$-pyrrole-2-carboxamide $(67 \mathrm{c})$. The title compound was synthesized according to general procedure $\mathrm{D}$ using $65 \mathrm{c}(182 \mathrm{mg}, 0.87 \mathrm{mmol})$ yielding $67 \mathrm{c}$ as a beige amorphous solid $(225 \mathrm{mg}, 56 \%) .{ }^{1} \mathrm{H}$ NMR (300MHz, DMSO-d6) $\delta 7.0(\mathrm{t}, J=6.6 \mathrm{~Hz}, 1 \mathrm{H}), 7.29(\mathrm{~s}, 1 \mathrm{H}), 7.30$ $(\mathrm{m}, 1 \mathrm{H}), 7.37(\mathrm{~d}, J=7.8 \mathrm{~Hz}, 1 \mathrm{H}), 7.52(\mathrm{t}, J=7.8 \mathrm{~Hz}, 1 \mathrm{H}), 7.68(\mathrm{~d}$, $J=9.1 \mathrm{~Hz}, 1 \mathrm{H}), 7.78(\mathrm{~s}, 1 \mathrm{H}), 7.80(\mathrm{~m}, 1 \mathrm{H}), 8.08(\mathrm{~s}, 1 \mathrm{H}), 8.62(\mathrm{~d}$, $J=6.7 \mathrm{~Hz}, 1 \mathrm{H}), 10.12(\mathrm{~s}, 1 \mathrm{H}), 13.02(\mathrm{~s}, 1 \mathrm{H}) .{ }^{13} \mathrm{C} \mathrm{NMR}(75 \mathrm{MHz}$, DMSO-d6) $\delta 98.2,106.1,113,114.2,117.7,118.3,119.2,122.5$, $124,124.6,125,127.8,129.2$, 129.8, 132.5, 139.6, 145.6, 157.5. HMRS (ESI) $m / z$ Calcd for $(\mathrm{M}+\mathrm{H})^{+} \mathrm{C}_{18} \mathrm{H}_{13} \mathrm{~N}_{4} \mathrm{OBr}_{2}: 460.9436$. Found: 460.9459. IR $\left(\mathrm{cm}^{-1}\right): 3158,1661,1609,1523,1422,1233$. 4,5-Dibromo- $N$-(3-(imidazo[1,2-a]pyrimidin-3-yl)phenyl)- $1 H$ pyrrole-2-carboxamide $(67 \mathrm{~d})$. The title compound was synthesized according to general procedure D using $65 \mathrm{~d}(100 \mathrm{mg}, 0.48$ mmol) yielding $67 \mathrm{~d}$ as a beige amorphous solid ( $80 \mathrm{mg}, 36 \%) .{ }^{1} \mathrm{H}$ NMR (300MHz, DMSO-d6) $\delta 7.06(\mathrm{dd}, J=4.3,6.8 \mathrm{~Hz}, 1 \mathrm{H}), 7.31$ $(\mathrm{s}, 1 \mathrm{H}), 7.43(\mathrm{t}, J=7.7 \mathrm{~Hz}, 1 \mathrm{H}), 7.69(\mathrm{~d}, J=7.7 \mathrm{~Hz}, 1 \mathrm{H}), 7.83(\mathrm{~d}, J$ $=7.7 \mathrm{~Hz}, 1 \mathrm{H}), 8.33(\mathrm{~s}, 1 \mathrm{H}), 8.36(\mathrm{~s}, 1 \mathrm{H}), 8.54(\mathrm{dd}, J=2.0,4.2 \mathrm{~Hz}$, $1 \mathrm{H}), 8.98$ (dd, $J=2.0,6.7 \mathrm{~Hz}, 1 \mathrm{H}), 10.01(\mathrm{~s}, 1 \mathrm{H}), 12.92(\mathrm{~s}, 1 \mathrm{H})$. ${ }^{13} \mathrm{C}$ NMR (75 MHz, DMSO-d6) $\delta 98.2,105.9,107.5,108.9,114$, 117.3, 119.7, 120.8, 127.9, 129.1, 133.8, 135.1, 139.4, 145.1, 148, 150.4, 157.3. HMRS (ESI) $\mathrm{m} / z$ Calcd for $(\mathrm{M}+\mathrm{H})^{+} \mathrm{C}_{17} \mathrm{H}_{12} \mathrm{~N}_{5} \mathrm{OBr}_{2}$ : 461.9388. Found: 461.9412. IR $\left(\mathrm{cm}^{-1}\right): 3188,1667,1612,1560$, $1416,1222$.

4,5-Dibromo- $N$-(4-(imidazo[1,2-a]pyrazin-3-yl)phenyl)- $1 H$-pyrrole-2-carboxamide $(68 \mathrm{a})$. The title compound was synthesized according to general procedure D using $66 \mathrm{a}(43 \mathrm{mg}, 0.20 \mathrm{mmol})$ yielding $68 \mathrm{a}$ as a beige amorphous solid ( $44 \mathrm{mg}, 51 \%) .{ }^{1} \mathrm{H}$ NMR (300MHz, DMSO-d6) $\delta 7.17(\mathrm{~s}, 1 \mathrm{H}), 7.70(\mathrm{~d}, J=8.5 \mathrm{~Hz}, 2 \mathrm{H}), 7.94$ (m, 3H), $8.02(\mathrm{~s}, 1 \mathrm{H}), 8.61$ (d, $J=4.7 \mathrm{~Hz}, 1 \mathrm{H}), 9.12$ (br s, $1 \mathrm{H})$, 12.86 (br s, $1 \mathrm{H}) .{ }^{13} \mathrm{C}$ NMR (75 MHz, DMSO-d6) $\delta 97.6,107.4$, $114,117.5,120.1,122,126.2$, 128.1, 128.6, 129.7, 134.1, 139.5, 140.7, 143.5, 158.2. HMRS (ESI) $\mathrm{m} / z$ Calcd for $(\mathrm{M}+\mathrm{H})^{+}$ $\mathrm{C}_{17} \mathrm{H}_{12} \mathrm{~N}_{5} \mathrm{OBr}_{2}$ : 461.9388. Found: 461.9369. IR $\left(\mathrm{cm}^{-1}\right): 3177$, 1639, 1524, 1412, 1332.

4,5-Dibromo- $N$-(4-(imidazo[1,2- $b]$ pyridazin-3-yl)phenyl)- $1 H$ pyrrole-2-carboxamide (68b). The title compound was synthesized according to general procedure D using $66 \mathrm{~b}(123 \mathrm{mg}, 0.59$ $\mathrm{mmol}$ ) yielding $\mathbf{6 8 b}$ as a beige amorphous solid $(98 \mathrm{mg}, 40 \%) .{ }^{1} \mathrm{H}$ NMR (300MHz, DMSO-d6) $\delta 7.28(\mathrm{~m}, 2 \mathrm{H}), 7.87(\mathrm{~d}, J=8.9 \mathrm{~Hz}$, $2 \mathrm{H}), 8.15$ (d, $J=8.9 \mathrm{~Hz}, 2 \mathrm{H}), 8.20$ (dd, $J=1.6,8.9 \mathrm{~Hz}, 1 \mathrm{H}), 8.24$ $(\mathrm{s}, 1 \mathrm{H}), 8.64(\mathrm{dd}, J=1.6,4.5 \mathrm{~Hz}, 1 \mathrm{H}), 10.0(\mathrm{~s}, 1 \mathrm{H}), 12.95(\mathrm{~s}, 1 \mathrm{H})$. ${ }^{13} \mathrm{C}$ NMR (75 MHz, DMSO-d6) $\delta 98.2,106.1,114,116.8,119.9$, 123.5, 126, 126.7, 127.2, 127.9, 132.3, 138.4, 139.6, 143.8, 157.3. HMRS (ESI) $m / z$ Calcd for $(\mathrm{M}+\mathrm{H})^{+} \mathrm{C}_{17} \mathrm{H}_{12} \mathrm{~N}_{5} \mathrm{OBr}_{2}: 461.9388$. Found: 461.9390. IR $\left(\mathrm{cm}^{-1}\right): 3179,1637,1598,1525,1409,1333$, 1159, 1022. 
4,5-Dibromo- $N$-(4-(imidazo[1,2-a]pyridin-3-yl)phenyl)- $1 H$-pyrrole-2-carboxamide $(68 \mathrm{c})$. The title compound was synthesized according to general procedure D using $66 \mathrm{c}(161 \mathrm{mg}, 0.77 \mathrm{mmol})$, yielding $68 \mathrm{c}$ as a beige amorphous solid $(140 \mathrm{mg}, 40 \%) .{ }^{1} \mathrm{H} \mathrm{NMR}$ $(300 \mathrm{MHz}, \mathrm{DMSO}-\mathrm{d} 6) \delta 6.97(\mathrm{t}, J=6.7 \mathrm{~Hz}, 1 \mathrm{H}), 7.29(\mathrm{~m}, 2 \mathrm{H})$, $7.65(\mathrm{~d}, J=8.0 \mathrm{~Hz}, 3 \mathrm{H}), 7.75(\mathrm{~s}, 1 \mathrm{H}), 7.93(\mathrm{~d}, J=8.0 \mathrm{~Hz}, 2 \mathrm{H}), 8.57$ $(\mathrm{d}, J=7.0 \mathrm{~Hz}, 1 \mathrm{H}), 10.05(\mathrm{~s}, 1 \mathrm{H}), 12.99(\mathrm{~s}, 1 \mathrm{H}) .{ }^{13} \mathrm{C}$ NMR $(75$ MHz, DMSO-d6) $898.2,106.1,112.8,114.1,117.4,120.4,123.7$, 124.1, 124.5, 124.9, 127.8, 128, 132, 138.6, 145.2, 157.4. HMRS (ESI) $\mathrm{m} / z$ Calcd for $(\mathrm{M}+\mathrm{H})^{+} \mathrm{C}_{18} \mathrm{H}_{13} \mathrm{~N}_{4} \mathrm{OBr}_{2}$ : 460.9436. Found: 460.9435. IR ( $\left.\mathrm{cm}^{-1}\right): 3169,1634,1595,1410,1310,1030$.

\section{General Procedure E for Click Reaction.}

Corresponding azide (1 eq.) was dissolved in $\mathrm{DMF} / \mathrm{H}_{2} \mathrm{O}(10: 2)$. The mixture was degased with bubbling argon $5 \mathrm{~min}$. Then sodium ascorbate ( $10 \mathrm{~mol} \%)$ was added followed by the alkyne $15 \mathrm{a}$ (1 eq.). $\mathrm{CuSO}_{4} .5 \mathrm{H}_{2} \mathrm{O}(1 \mathrm{~mol} \%)$ was finally added to the reaction mixture. It was stirred at room temperature overnight under argon. The mixture was filtered, rinsed with DCM then with water. The resulting solid was dried to afford the desired triazole.

4,5-Dibromo- $N$-((1-(imidazo[1,2-a] pyrazin-3-ylmethyl)-1 $H$ 1,2,3-triazol-4-yl)methyl)-1 $H$-pyrrole-2-carboxamide (71a). The title compound was synthesized according to general procedure $\mathrm{E}$ using 70a (146 mg, $0.84 \mathrm{mmol}$ ) and 15a (256 mg, $0.84 \mathrm{mmol}$ ), yielding $71 \mathrm{a}$ as a white amorphous solid $(310 \mathrm{mg}, 77 \%) .{ }^{1} \mathrm{H}$ NMR (300MHz, DMSO-d6) $\delta 4.42(\mathrm{~d}, J=6.0 \mathrm{~Hz}, 2 \mathrm{H}), 6.09(\mathrm{~s}, 2 \mathrm{H})$, $6.92(\mathrm{~s}, 1 \mathrm{H}), 8.01(\mathrm{~m}, 2 \mathrm{H}), 8.06(\mathrm{~s}, 1 \mathrm{H}), 8.59(\mathrm{t}, J=6.0 \mathrm{~Hz}, 1 \mathrm{H})$, $8.64(\mathrm{~m}, 1 \mathrm{H}), 9.12(\mathrm{~s}, 1 \mathrm{H}), 12.69(\mathrm{~s}, 1 \mathrm{H}) .{ }^{13} \mathrm{C} \mathrm{NMR}(75 \mathrm{MHz}$, DMSO-d6) $\delta 34.1,41.6,97.8,104.8,112.9,118.2,123,123.7$, $127.9,129.3,136,143.3,145.3,158.8$. Some quaternary carbons and aromatic $\mathrm{CH}$ too broad to be seen due to very slow relaxation.

Protein kinase assays. Kinase enzymatic activities were assayed in 384-well plates using the ADP-GloTM assay kit (Promega, Madison, WI). This assay provides an homogeneous and high-throughput screening method to measure kinase activity by quantifying the amount of $\mathrm{ADP}$ produced during a kinase reaction. ${ }^{82}$ Briefly, the reactions were carried out in a final volume of $6 \mu \mathrm{l}$ for $30 \mathrm{~min}$ at $30^{\circ} \mathrm{C}$ in appropriate kinase buffer, with either protein or peptide as substrate in the presence of $10 \mu \mathrm{M}$ ATP (40mM Tris $\mathrm{pH} 7.5$, $20 \mathrm{mM} \mathrm{MgCl} 2$ and $0.1 \mathrm{mg} / \mathrm{ml}$ of BSA). Afterwards, $6 \mu \mathrm{l}$ of ADPGloTM Kinase Reagent was added to stop the kinase reaction. After an incubation time of $50 \mathrm{~min}$ at room temperature (RT), $12 \mu \mathrm{l}$ of Kinase Detection Reagent was added for one hour at RT. The transmitted signal was measured using the Envision (PerkinElmer, Waltham, MA) microplate luminometer and expressed in Relative Light Unit (RLU). In order to determine the half maximal inhibitory concentration $\left(\mathrm{IC}_{50}\right)$, the assays were performed in duplicate in the absence or presence of increasing doses of the tested

compounds. Kinase activities are expressed in \% of maximal activity, i.e. measured in the absence of inhibitor. Peptide substrates were obtained from Proteogenix (Schiltigheim, France). Aurora B kinase assay was validated using a model inhibitor employed under the same conditions as those for the tested compounds: ZM447439 (\#S1103, Selleckchem).
HMRS (ESI) $m / z$ Calcd for $(\mathrm{M}+\mathrm{H})^{+} \mathrm{C}_{15} \mathrm{H}_{13} \mathrm{Br}_{2} \mathrm{~N}_{8} \mathrm{O}: 480.9559$. Found: 480.9598. IR $\left(\mathrm{cm}^{-1}\right): 3443,3277,1630,1564,1525,1405$, 1229.

4,5-Dibromo- $N$-((1-(imidazo[1,2-b] pyridazin-3-ylmethyl)- $1 H$ 1,2,3-triazol-4-yl)methyl)-1 H-pyrrole-2-carboxamide (71b). The title compound was synthesized according to general procedure $\mathrm{E}$ using $70 \mathrm{~b}$ (127 mg, $0.73 \mathrm{mmol}$ ) and $15 \mathrm{a}(223 \mathrm{mg}, 0.73 \mathrm{mmol})$, yielding $71 \mathbf{b}$ as a white amorphous solid (310 mg, 89\%). ${ }^{1} \mathrm{H}$ NMR (300MHz, DMSO-d6) $\delta 4.41(\mathrm{~d}, J=5.8 \mathrm{~Hz}, 2 \mathrm{H}), 5.99(\mathrm{~s}, 2 \mathrm{H})$, $6.92(\mathrm{~s}, 1 \mathrm{H}), 7.30$ (dd, $J=4.6,9.2 \mathrm{~Hz}, 1 \mathrm{H}), 7.95$ (s, 2H), 8.18 (dd, $J=1.5,9.2 \mathrm{~Hz}, 1 \mathrm{H}), 8.58(\mathrm{~m}, 2 \mathrm{H}), 12.69(\mathrm{~s}, 1 \mathrm{H}) .{ }^{13} \mathrm{C} \mathrm{NMR}(75$ MHz, DMSO-d6) $\delta 34.1,41.9,97.8,104.7,112.8,118,122.3$, $122.9,125.9,127.9,134.2,144,145,146.2,158.7$. HMRS (ESI) $\mathrm{m} / z$ Calcd for $(\mathrm{M}+\mathrm{H})^{+} \mathrm{C}_{15} \mathrm{H}_{13} \mathrm{Br}_{2} \mathrm{~N}_{8} \mathrm{O}$ : 480.9559. Found: 480.9564. IR $\left(\mathrm{cm}^{-1}\right): 3146,3128,1635,1566,1523,1243$.

4,5-Dibromo- $N$-((1-(imidazo[1,2-a]pyridin-3-ylmethyl)-1 $H$ 1,2,3-triazol-4-yl)methyl)-1 $H$-pyrrole-2-carboxamide (71c).

The title compound was synthesized according to general procedure E using 70c (202 mg, 1.2 mmol) and 15a (356 mg, $1.2 \mathrm{mmol})$, yielding $71 \mathrm{c}$ as a white amorphous solid $(349 \mathrm{mg}, 63 \%) .{ }^{1} \mathrm{H}$ NMR (300MHz, DMSO-d6) $\delta 4.41(\mathrm{~d}, J=5.7 \mathrm{~Hz}, 2 \mathrm{H}), 6.03(\mathrm{~s}, 2 \mathrm{H})$, $6.91(\mathrm{~s}, 1 \mathrm{H}), 7.0(\mathrm{t}, J=6.8 \mathrm{~Hz}, 1 \mathrm{H}), 7.31(\mathrm{t}, J=6.8 \mathrm{~Hz}, 1 \mathrm{H}), 7.62$ $(\mathrm{m}, 1 \mathrm{H}), 7.78(\mathrm{~m}, 1 \mathrm{H}), 7.99(\mathrm{~s}, 1 \mathrm{H}), 8.55(\mathrm{~m}, 1 \mathrm{H}), 8.6(\mathrm{t}, J=5.6$ $\mathrm{Hz}, 1 \mathrm{H}), 12.69(\mathrm{~s}, 1 \mathrm{H}) .{ }^{13} \mathrm{C}$ NMR (75 MHz, DMSO-d6) $\delta 34.1$, 42.2, 97.8, 104.7, 112.5, 112.9, 117.2, 122.8, 124.8, 125, 127.9, $134.3,145.2,147,158.7$. Some quaternary carbons and aromatic $\mathrm{CH}$ too broad to be seen due to very slow relaxation. HMRS (ESI) $\mathrm{m} / z$ Calcd for $(\mathrm{M}+\mathrm{H})^{+} \mathrm{C}_{16} \mathrm{H}_{14} \mathrm{Br}_{2} \mathrm{~N}_{7} \mathrm{O}$ : 479.9606. Found: 479.9621. IR $\left(\mathrm{cm}^{-1}\right): 3263,1629,1519,1501,1407,1317,1227$.

Buffers: (A) $10 \mathrm{mM} \mathrm{MgCl2,} 1 \mathrm{mM}$ EGTA, $1 \mathrm{mM}$ DTT, $25 \mathrm{mM}$ Tris- $\mathrm{HCl} \mathrm{pH} 7.5,50 \mu \mathrm{g} / \mathrm{ml}$ heparin; (B) $25 \mathrm{mM}$ MOPS, pH7.2, $12.5 \mathrm{mM} \beta$-glycerophosphate, $25 \mathrm{mM} \mathrm{MgCl}$, 5 mM EGTA, $2 \mathrm{mM}$ EDTA, 0.25 mM DTT.

In this study the following protein kinases were analyzed: AuroraB (human, recombinant, expressed by baculovirus in Sf9 insect cells, SignalChem, product \#A31-10G) was assayed in buffer B with 0.2 $\mu \mathrm{g} / \mu \mathrm{l}$ of myelin basic protein (MBP) as substrate; CDK2/CyclinA (cyclin-dependent kinase-2, human kindly provided by Dr. A. Echalier-Glazer, Leicester, UK) was assayed in buffer A with 0.8 $\mu \mathrm{g} / \mu \mathrm{l}$ of histone $\mathrm{H} 1$ as substrate; CDK5/p25 (human, recombinant, expressed in bacteria) was assayed in buffer A with $0.8 \mu \mathrm{g} / \mu \mathrm{l}$ of histone $\mathrm{H} 1$ as substrate; CDK9/CyclinT (human, recombinant, expressed by baculovirus in Sf9 insect cells) were assayed in buffer A with $0.27 \mu \mathrm{g} / \mu \mathrm{l}$ of the following peptide: YSPTSPSYSPTSPSYSPTSPSKKKK, as substrate; GSK3 $\beta$ (human, recombinant, expressed by baculovirus in $\mathrm{Sf} 9$ insect cells) were assayed in buffer A with $0.010 \mu \mathrm{g} / \mu \mathrm{l}$ of GS-1 peptide, a GSK3-selective substrate (YRRAAVPPSPSLSRHSSPHQSpEDEEE); $\mathrm{CK} 1 \varepsilon$ (human, recombinant, expressed by baculovirus in Sf9 insect cells) was assayed in buffer A with $0.022 \mu \mathrm{g} / \mu \mathrm{l}$ of the following peptide: RRKHAAIGSpAYSITA ("Sp" stands for phosphorylated serine) as CK1-specific substrate; Haspin-kd (human, kinase domain, amino acids 470 to 798 , recombinant, expressed in bacteria) was assayed in buffer A with $0.007 \mu \mathrm{g} / \mu \mathrm{l}$ of Histone $\mathrm{H} 3$ (1-21) peptide (ARTKQTARKSTGGKAPRKQLA) as substrate; Pim-1 (human proto-oncogene, recombinant, expressed in bacteria) was assayed 
in buffer A with $0.8 \mu \mathrm{g} / \mu \mathrm{l}$ of histone H1 (Sigma \#H5505) as substrate; MmCLK1 (from Mus musculus, recombinant, expressed in bacteria) was assayed in buffer A with $0.027 \mu \mathrm{g} / \mu \mathrm{l}$ of the following peptide: GRSRSRSRSRSR as substrate; RnDYRK1A-kd (Rattus norvegicus, amino acids 1 to 499 including the kinase domain, recombinant, expressed in bacteria, DNA vector kindly provided by Dr. W. Becker, Aachen, Germany) was assayed in buffer A with $0.033 \mu \mathrm{g} / \mu \mathrm{l}$ of the following peptide: KKISGRLSPIMTEQ as substrate.

ATP competition assay. Human recombinant Aurora B activity was assayed in vitro, according to the ADP-Glo method (Promega), in the absence or presence of CJ2-150 (2; $1 ; 0.5$ or 0.1 $\mu \mathrm{M})$ and increasing concentrations of $\operatorname{ATP}(3,125$ to $50 \mu \mathrm{M})$. The kinase assay was performed, in triplicate, in buffer B with $0.2 \mu \mathrm{g} / \mu \mathrm{l}$ of $\operatorname{MBP}(0.2 \mu \mathrm{g} / \mu \mathrm{l})$ as substrate in buffer $B$ and carried out in a final volume of $6 \mu \mathrm{l}$ for $30 \mathrm{~min}$ at $30^{\circ} \mathrm{C}$. The reaction was then continued as described above (cf. part Protein kinase assays). The signals obtained, expressed in RLU, allow drawing of a double-reciprocal plot of the Michaelis-Menten equation (also known as the Lineweaver-Burk plot).

Immunofluorescence. For immunofluorescence experiments, cells were grown on glass coverslips, fixed with $4 \%$ paraformaldehyde in PBS, permeabilized by $0.15 \%$ Triton-X100 for 2 minutes and processed using standard protocols. Images were acquired with a Coolsnap HQ2 CCD camera (Photometrics) on a Zeiss Axio microscope (Carl Zeiss) us-ing a 100x NA 1.40 objective. Image acquisition and processing were performed using Metamorph (Molecular Device). Deconvolution was performed using the AutoQuant module in Metamorph. Quantification of signal intensity was performed using ImageJ software (NIH). Primary antibodies used in this study included rabbit polyclonal anti-phospho-Ser10 Histone H3 (1/1000 dilution, Millipore), rabbit polyclonal antiAurora B (1/100, Life Technologies) and mouse monoclonal anti$\alpha$-Tubulin (Clone B512, Sigma).

Cell Culture and Proliferation Assay. Cancer cell lines were obtained from the American Type Culture Collection (Rockville, MD, USA) or from the European collection of cell culture (ECACC, England) and were cultured according to the supplier's instructions. K562R (doxorubicin-resistant) leukemia cells were a generous gift from Pr. J.P. Marie (France). Human HCT-116 colorectal carcinoma, MCF7 breast adenocarcinoma, A549 lung carcinoma, U2OS osteosarcoma and SK-OV-3 ovary carcinoma were grown in Gibco McCoy's 5A supplemented with $10 \%$ fetal calf serum and $1 \%$ glutamine. K562 and K562R leukemia cells were grown in RPMI 1640 supplemented with $10 \%$ fetal calf serum and $1 \%$ glutamine. hTERT-RPE1 cells were cultured in DMEM/F12 medium containing $10 \%$ fetal calf serum and $1 \%$ glutamine. Cells were maintained at $37^{\circ} \mathrm{C}$ in a humidified atmosphere containing $5 \% \mathrm{CO}_{2}$.
Cell viability was determined by a luminescent assay according to the manufacturer's instructions (Promega, Madison, WI, USA). For $\mathrm{IC}_{50}$ determination, the cells were seeded in 96-well plates ( 3 $\times 10^{3}$ cells/well) containing $90 \mu \mathrm{L}$ of growth medium. After $24 \mathrm{~h}$ of culture, the cells were treated with the tested compounds at 10 different final concentrations. Each concentration was obtained from serial dilutions in culture medium starting from the stock solution. Control cells were treated with the vehicle. Experiments were performed in triplicate.

After $72 \mathrm{~h}$ of incubation, $100 \mu \mathrm{L}$ of CellTiter Glo Reagent was added for $15 \mathrm{~min}$ before recording luminescence with a spectrophotometric plate reader PolarStar Omega (BMG LabTech). The dose-response curves were plotted with Graph Prism software and the $\mathrm{IC}_{50}$ values were calculated using the Graph Prism software from polynomial curves (four or five-parameter logistic equations).

PBMC Viability Assay. Isolation of periferal blood mononuclear cells (PBMC) from human donor blood samples was performed by Ficoll density gradient centrifugation. The separated PBMC were resuspended at a final concentration of $5.56 \times 105$ cells $/ \mathrm{mL}$ in RPMI media supplemented with $10 \%$ fetal bovine serum. Cell viability assays were performed on both phytohemagglutinin (PHA)activated and non-activated PMBC using the luminescent CellTiter-Glo protocol from Promega.

Cell cycle analysis. After $24 \mathrm{~h}$ of treatment with CJ2-151, K562 cells were fixed in $70 \%$ ethanol and stained with propidium iodide solution containing RNase A. DNA content was further determined by flow cytometry using FC500 (Beckman Coulter).

Molecular docking. Three-dimensional structures of the ligands were generated using CORINA 4.2.0 (Molecular Networks GmbH, Germany and Altamira, LLC, USA). Molecular docking calculations were performed using the GOLD software ${ }^{83}$ from the CCDC_2020 suite, with the Aurora B structure 4AF3 ${ }^{71}$ as receptor and the GoldScore scoring function. The interaction between $\mathrm{Au}$ rora $B$ and the INCENP protein structure $4 \mathrm{AF} 3$ cover both " $F$ " and " $Y$ " sites, therefore ensuring that these two sites are accessible for docking. The site "F" was defined as a sphere with 10 Å diameter around a virtual point situated at mid-distance between the atoms CE2 of Phe72 and CZ of Phe101. The site "Y" was defined as a sphere with $10 \AA$ diameter around the atom CD1 of Ile150. All other parameters had default values and 50 conformers were generated for each site. The analysis of docking poses was performed with UCSF Chimera, ${ }^{84}$ as well as the generation of molecular modeling images.

\section{ASSOCIATED CONTENT}

Supporting Information
The Supporting Information is available free of charge on the ACS Publications website. Additional experimental procedures, NMR spectra, specificity inhibition table, Dose-effect PBMC viability, MickaelisMenten graph for ATP competition, docking conformation of 
compound CJ2-150 in the "F" allosteric site, ELSD-HPLC Profiles and the CSV file with formula strings with the associated biochemical and biological data.

\section{AUTHOR INFORMATION}

\section{Corresponding Authors}

*ali.almourabit@cnrs.fr (A. Al-Mourabit)

*sandrine.ruchaud@sb-roscoff.fr(Sandrine Ruchaud)

\section{Author Contributions}

Charlotte Juillet did most of the synthetic work as well as most of the biological analysis and the mode of action studies, and co-authored the manuscript.

Ludmila Ermolenko and Dina Boyarskaya prepared some analogs Blandine Baratte performed biochemical experiments and cowrote the experimental part.

Béatrice Josselin performed biological evaluations.

Sandrine Ruchaud and Stéphane Bach co-supervised the screening against protein kinases. Sandrine Ruchaud, supervised the biological and biochemical evaluation and co-authored the manuscript.

Jerome Bignon, supervised the cell cycle analysis and co-authored the corresponding experimental part.

Hristo Nedev carried out the molecular modeling experiments and analyzed the results.

Bogdan I. Iorga, analyzed the docking results and co-authored the manuscript.

Ali Al-Mourabit conceived and directed the project, supervised the findings of this work and co-authored the manuscript.

Funding Sources

\section{Graphical Abstract}

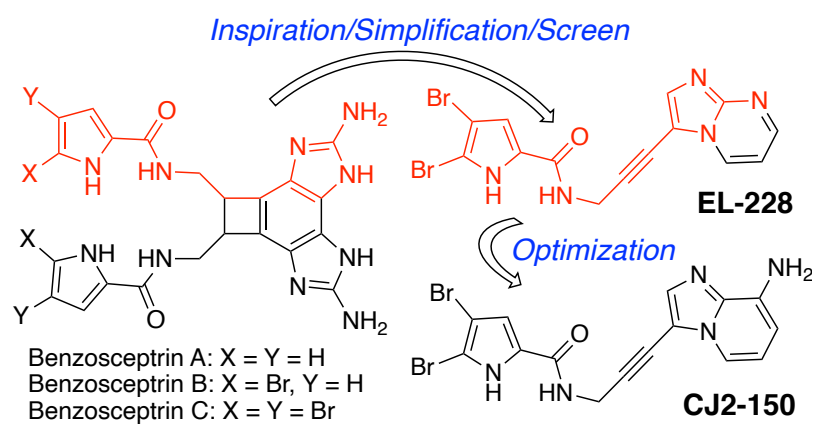

CNRS, Cancéropôle Grand-Ouest and La Ligue Contre le Cancer

\section{Conflict of interest}

Stéphane Bach is a founder and member of the scientific advisory board of SeaBeLife Biotech, which is developing novel therapies for treating liver and kidney acute disorders. This work was conducted in the absence of any commercial or financial relationships that could be construed as a potential conflict of interest.

\section{ABBREVIATIONS}

CK1, Casein kinase 1; CPC, chromosomal passenger complex; DAPI, 4',6-diamidino-2-phenylindole; DTT, dithiothreitol; EDCI, 1-Ethyl3-(3-dimethylaminopropyl)carbodiimide; EGTA, ethylene glycolbis( $\beta$-aminoethyl ether)-N,N,N',N'-tetraacetic acid; ELSD, Evaporative light scattering detector; ESI-TOF, Electrospray Ionization Timeof-Flight; FACS, Fluorescence-activated Cell Sorting; HPBT, 1-Hydroxybenzotriazole; INCENP, Inner centromere protein; IR, infrared; MBP, myelin basic protein; MOPS, 3-(N-morpholino)propanesulfonic acid; PBMCs, peripheral blood mononuclear cells, PHA, phytohemagglutinine; RLU; Relative Light Unit; SAC, spindle assembly checkpoint.

\section{ACKNOWLEDGMENT}

The authors thank Dr. Robert H. Dodd for careful reading and improvements of the manuscript with regard to English usage. We thank Céline Moriou for the HPLC profiles, Marine Peyneau and Luc Dechaisemartin (Paris-Saclay, Inserm, Châtenay-Malabry) for PBMC viability assay. We thank Paris-Saclay University for doctoral fellowships.

Financial support from CNRS is gratefully acknowledged. The authors wish to thank: Cancéropôle Grand-Ouest, French IBiSA and Biogenouest for supporting the KISSf screening facility, FR2424 (Roscoff, France). The authors also wish to thank "La Ligue Contre le Cancer" committee (Districts 29, 22, 56, 45 and 79) for financial support.

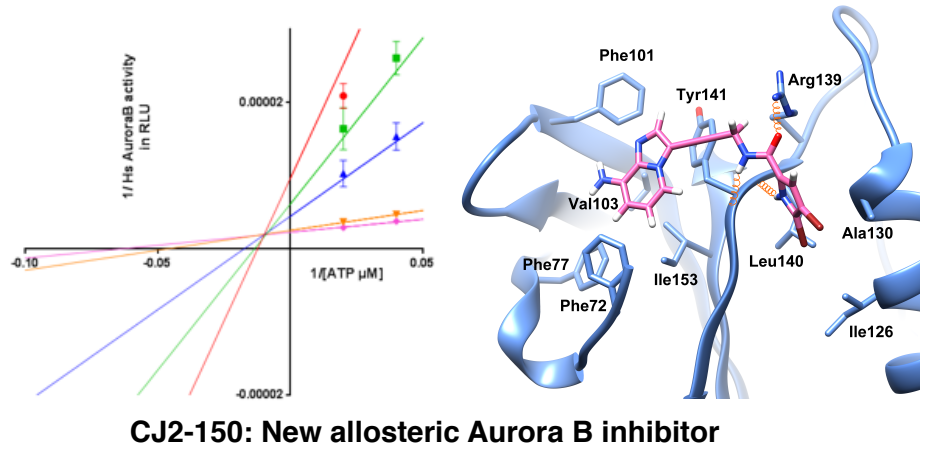

\section{REFERENCES}


(1) Vader, G.; Lens, S.M.A. The Aurora Kinase Family in Cell Division and Cancer. Biochim. Biophys. Acta. 2008, 1786, 60-72.

(2) Carmena, M.; Wheelock, M.; Funabiki, H.; Earnshaw, W. C. The Chromosomal Passenger Complex (CPC): From Easy Rider to the Godfather of Mitosis. Nature Rev. Mol. Cell. Biol. 2012, 13, 789-803.

(3) Van der Waal, M. S.; Hengeveld, R. C. C.; van der Horst, A.; Lens, S. M. A. Cell Division Control by the Chromosomal Passenger Complex. Exp. Cell Res. 2012, 318, 1407-1420.

(4) Gurley, L. R.; D’anna, J. A.; Barham, S. S.; Deaven, L. L.; Tobey, R. A. Histone Phosphorylation and Chromatin Structure during Mitosis in Chinese Hamster Cells. Eur. J. Biochem. 1978, 84, 1-15.

(5) Willems, E.; Dedobbeleer, M.; Digregorio, M.; Lombard, A.; Lumapat, P. N.; Rogister, B. The Functional Diversity of Aurora Kinases: A Comprehensive Review. Cell Div. 2018, 13, 1-17.

(6) Sarangapani, K. K.; Asbury, C. L. Catch and Release: How Do Kinetochores Hook the Right Microtubules during Mitosis? Trends Genet. 2014, 30, $150-159$.

(7) Krenn, V.; Musacchio, A. The Aurora B Kinase in Chromosome Bi-Orientation and Spindle Checkpoint Signaling. Front. Oncol. 2015, 5, 225. doi: $10.3389 /$ fonc.2015.00225

(8) Lens, S. M. A.; Medema, R. H. Cytokinesis Defects and Cancer, Nat. Rev. Cancer, 2019, 19, 32-45.

(9) Steigemann,P.; Wurzenberger, C.; Schmitz, M.H.A.; Held, M.; Guizetti, J.; Maar, S.; Gerlich, D.W. Aurora B-Mediated Abscission Checkpoint Protects against Tetraploidization, Cell, 2009, 136, 473-484.

(10) Ruchaud, S.; Carmena, M.; Earnshaw, W. C. Chromosomal Passengers: Conducting Cell Division. Nat. Rev. Mol. Cell. Biol. 2007, 8, 798-812.

(11) Keen, N.; Taylor, S. Aurora-Kinase Inhibitors as Anticancer Agents. Nat. Rev. Cancer, 2004, 4, 927-936.

(12) Sen, S.; Zhou, H.; White, R. A. A Putative Serine/Threonine Kinase Encoding Gene BTAK on Chromosome 20q13 is Amplified and Overexpressed in Human Breast Cancer Cell Lines. Oncogene. 1997, 14, 2195-2200.

(13) Bischoff, J. R. A Homologue of Drosophila Aurora Kinase Is Oncogenic and Amplified in Human Colorectal Cancers. EMBO J. 1998, 17, 3052-3065.

(14) Pollard, J .R.; Mortimore, M. Discovery and Development of Aurora Kinase Inhibitors as Anticancer Agents, J. Med. Chem. 2009, 52, 2629-2651.

(15) Bavetsias, V.; Large, J. M.; Sun, C.; Bouloc, N.; Kosmopou-lou, M.; Matteucci, M.; Wilsher, N. E.; Martins, V.; Reynis-son, J.; Atrash, B.; Urban, F.; Valenti, M.; De Haven Bran-don, A.; Box, G.; Raynaud, F. I.; Workman, P.; Eccles, S. A.; Bayliss, R.; Blagg, J.; Linardopoulos, S.; McDonald, E. Imid-azo[4,5b]pyridine Derivatives As Inhibitors of Aurora Ki-nases: Lead Optimization Studies toward the Identification of an Orally Bioavailable Preclinical Development Candidate, J. Med. Chem. 2010, 53, 5213-5228

(16) Sharma, A.; Luxami, V.; Paul, K. Purine-benzimidazole Hybrids: Synthesis, Single Crystal Determinationand in vitro Evaluation of Antitumor Activities, Eur. J. Med. Chem. 2015, 93, 414-422.

(17) Borisa, A. C.; Bhatt, H. G. A Comprehensive Review on Aurora Kinase: Small Molecule Inhibitors and Clinical Trial Studies. Eur.J. Med. Chem. 2017, 140, 1-19.

(18) Dar, A. A.; Goff, L. W.; Majid, S.; Berlin, J.; El-Rifai, W. Aurora Kinase Inhibitors - Rising Stars in Cancer Therapeutics? Mol. Cancer Ther. 2010, 9, 268-278

(19) Carles, F.; Bourg, S.; Meyer, C.; Bonnet, P. PKIDB: A Curated, Annotated and Updated Database of Protein Kinase Inhibitors in Clinical Trials. Molecules. 2018, 23, 908.

(20) Wang, S.; Dong, G.; Sheng, C. Structural Simplification of Natural Products. Chem. Rev. 2019, 119, 4180-4220.

(21) Al-Mourabit, A.; Zancanella, M. A.; Tilvi, S.; Romo, D. Biosynthesis, Asymmetric Synthesis, and Pharmacology Including Cellular Targets of the Pyrrole-2-Aminoimidazole Marine Alkaloids. Nat. Prod. Rep. 2011, 28, $1229-1260$.

(22) Appenzeller, J.; Tilvi, S.; Martin, M.-T.; Gallard, J.-F.; El-bitar, H.; Dau, E. T. H.; Debitus, C.; Laurent, D.; Moriou, C.; Al-Mourabit, A. Benzosceptrins A and $B$ with a Unique Benzocyclobutane Skeleton and Nagelamide $S$ and $\mathrm{T}$ from Pacific Sponges. Org. Lett. 2009, 11, 4874-4877
(23) Kubota, T.; Araki, A.; Yasuda, T.; Fromont, J.; Aoyama, K.; Mikami, Y.; Walchli, M.R.; Kobayashi, J. Benzosceptrin C, a New Dimeric Bromopyrrole Alkaloid from Sponge Agelas sp. Tetrahedron Lett. 2009, 50, 7268-7270.

(24) Tran, M. Q.; Nguyen, T. B.; Sawadogo, W. R.; Ermolenko, L.; Song, S.; Retailleau, P.; Diederich, M.; Al-Mourabit, A. Unaromatized Tetrahydrobenzimidazole Synthesis from $\mathrm{p}$-Benzoquinone and N-Arylamidines and their $\mathrm{Cy}$ totoxic Potential, Eur. J. Org. Chem. 2018, 5878-5884.

(25) Song, S.; Lee, J.-Y.; Ermolenko, L.; Mazumder, A.; Ji, S.; Ryu, H.; Kim, H.; Kim, D.-W.; Lee, J.-W.; MDicato, M.; Christov, C.; Schnekenburger, M.; Cerella, C.; Gérard, D.; Boyer, B.-O.; Al-Mourabit, A.; Diederich, M. Tetrahydrobenzimidazole TMQ0153 triggers Apoptosis, Autophagy and Necroptosis Crosstalk in Chronic Myeloid Leukemia. Cell Death \& Disease, 2020, 11:109. (26) Benchekroun, M.; Ermolenko, L.; Tran M. Q.; A. Vagneux, A.; Nedev, H.; Delehouzé, C.; Souab, M.; Baratte, B.; Josselin, B.; Iorga, B.-I.; Ruchaud, S.; Bach, S.; Al-Mourabit, A. Discovery of Simplified Benzazole Fragments Derived from the Marine Benzosceptrin B as Necroptosis Inhibitors Involving the Receptor Interacting Protein Kinase-1, Eur. J. Org. Chem, 2020, 201:112337. doi.org/10.1016/j.ejmech.2020.112337.

(27) Sasmal, P.K.; Chandrasekhar, A.; Sridhar, A.; Iqbal, J. Novel one-step Method for the Conversion of Isothiocyanates to 2-Alkyl(aryl)aminothiazoles, Tetrahedron, 2008, 64, 11074-11080.

(28) Rivall, Y.; Grassyl, G.; Taudou, A.; Ecalle, R. Antifungal Activity in vitro of some Imidazo[1,2-alpyrimidine Derivatives, Eur. J. Med. Chem., 1991, 26, $13-18$.

(29) Lindel, T.; Hochgurtel, M. Synthesis of the Marine Natural Product Oroidin and Its Z-Isomer, J. Org. Chem. 2000, 65, 2806-2809

(30) Dasgupta, R.; Rajalu, G.G.; Dickson, J.K. Novel Oxazole Compounds as $\beta$-Catenin Modulators and Uses thereof, WO2016/81451, 2016.

(31) Yasui, K.; Morioka, Y.; Hanasaki, K.; Antipruritics, EP1477186, 2004.

(32) Kuwano, R.; Kashiwabara, M.; Ohsumi, M.; Kusano, H. Catalytic Asymmetric Hydrogenation of 2,3,5-Trisubstituted Pyrroles, J. Am. Chem. Soc. 2008, 130, 3, 808-809

(33) Essa, A.H.; Lerrick, R.I.; Tuna, F.; Harrington, R.W.; Clegg, W.; Hall, M.J. Reduction of 2,2,2-Trichloro-1-Aryl-Ethanones by RMgX: Mechanistic Investigations and the Synthesis of Substituted $\alpha, \alpha$-Dichloro-Ketones, Chem.Commun. 2013, 49, 2756-2758.

(34) Ponasik, J.A.; Kassab, D.J.; Ganem, B. Synthesis of the Antifouling PolyAmine Pseudoceratidine and its Analogs: Factors Influencing Biocidal Activity, Tetrahedron Lett. 1996, 37, 6041-6044.

(35) Clark, B.R.; O’Connor, S.; Fox, D.; Leroy, J.; Murphy, C.D.Org. Production of Anticancer Polyenes through Precursor-directed Biosynthesis, Biomol. Chem. 2011, 9, 6306-6311

(36) Allmann, T.M.; Moldovan, R.P.; Jones, P.G.; Lindel, T. Synthesis of Hydroxypyrrolone Carboxamides Employing Selectfluor, Chem. Eur.J. 2016, 22, $111-115$

(37) Huigens, R.B.; Rogers, S.A.; Steinhauer, A.T.; Melander, A 2-Aminobenzimidazole That Inhibits and Disperses Gram-Positive Biofilms through a ZincDependent Mechanism, C. Org. Biomol. Chem. 2009, 7, 794-802

(38) Poverlein, C.; Jacobi, N.; Mayer, P.; Lindel, T. Synthesis of 4(5)-Acyl-2aminoimidazoles and Vinylogues, Synthesis, 2007, 23, 3620-3626.

(39) Loeber, S.; Huebner, H.; Gmeiner, P. Azaindole Derivatives with High Affinity for the Dopamine D4 Receptor: Synthesis, Ligand Binding Studies and Comparison of Molecular Electrostatic Potential Maps, Bioorg. Med. Chem. Lett. 1999, 9, 97-102.

(40) Enguehard, C.; Renou, J.L. ; Collot, V. ; Hervet, M. ; Rault, S. ; Gueiffier, A. Reactivity of 3-Iodoimidazo[1,2-a]pyridines Using a Suzuki-Type CrossCoupling Reaction, J. Org. Chem. 2000, 65, 6572-6575.

(41) Jingtao, C.; Xuanping, G.; Meng, H.; Xinsheng, L.; Method for Synthesizing 3-Iodoimidazo[1,2-b]pyrazine, CN105218549A, 2016.

(42) Sablayrolles, C.; Cros, G.H.; Milhavet, J.C.; Rechenq, E.; Chapat, J.P.; Boucard, M.; Serrano, J.J.; McNeill, J.H. Synthesis of Imidazo[1,2-a ]pyrazine Derivatives with Uterine-Relaxing, Antibronchospastic, and Cardiac-Stimulating, Properties J. Med. Chem. 1984, 27, 206-212.

(43) Reddy, K.; Martinez Botella, G.; Griffin, A.M.; Marron, B.E. Compounds and their Methods of Use, WO2018098500A1, 2018. 
(44) Bischoff, F.P.; Berthelot, D.; De Cleyn, M.; Macdonald, G.; Minne, G.; Oehlrich, D.; Pieters, S.; Surkyn, M.; Trabanco, A.A.; Tresadern, G.; Van Brandt, S.; Velter, I.; Zaja, M.; Borghys, H.; Masungi, C.; Mercken, M.; Gijsen, H.J.M. Design and Synthesis of a Novel Series of Bicyclic Heterocycles as Potent $\gamma$-Secretase Modulators, J. Med. Chem. 2012, 55, 9089-9106.

(45) El Akkaoui, A. ; Bassoude, I. ; Koubachi, J. ; Berteina-Raboin, S. ; Mouaddib, A. ; Guillaumet, G. Pd-catalyzed Regiocontrolled Sonogashira and Suzuki Cross-coupling Reaction of 3,6-Dihalogenoimidazo[1,2-a]pyridines: One-pot Double-coupling Approach, Tetrahedron, 2011, 67, 7128-7138.

(46) Mu, B. ; Li, J. ; Zou, D. ; Wu, Y. ; Chang, J. ; Wu, Y. Pd-Catalyzed Tandem Cyclization via $\mathrm{C}-\mathrm{H}$ Arylation and Acylation for the Construction of Polycyclic Scaffolds, Org. Lett. 2016, 18, 5260-5263.

(47) Gardan, S.; Mayer, S.; Stephan, S. New adenosine Receptor Ligands and Uses Thereof, EP2210891, 2019.

(48) Barda, D.A.; Burkholder, T.P.; Clayton, J.R.; Hao, Y.; Heath, P.C.; Henry, J.R.; Knobeloch, J.M.; Mendel, D.; McLean, J.A.; Remick, D.M.; Rempala, M.E.; Wang, Z.Q.; Yip, Y.Y.M.; Zhong, B. Imidazo (1,2-a)pyridine Compounds as Vegf-R2 inhibitors, WO 2006/91671, 2006.

(49) Berdini, V.; Besong, G.E.; Callaghan, O.; Carr, M. G.; Congreve, M.S.; Gill, A.L.; Griffiths-Jones, C.M.; Madin, A.; Murray, C.W.; Nijjar, R.K.; O’Brien, M.A.; Pike, A.; Saxty, G.; Taylor, R.D.; Vickerstaffe, E. New Compounds, WO2008/78100, 2008.

(50) Baltus, C. B.; Jorda, R.; Marot, C.; Berka, K.; Bazgier, V.; Krystof, V.; Prié, G.; Viaud-Massuard, M.C. Synthesis, Biological Evaluation and Molecular Modeling of a Novel Series of 7-Azaindole Based Tri-heterocyclic Compounds as Potent CDK2/Cyclin E Inhibitors, Eur.J. Med. Chem. 2016, 108, 701-719.

(51) Tichenor, M.S.; Keith, J.M.; Jones, W.M.; Pierce, J.M.; Merit, J.; Hawryluk, N.; Seierstad, M.; Palmer, J.A.; Webb, M.; Karbarz, M.J.; Wilson, S.J.; Wennerholm, M.L.; Woestenborghs,F.; Beerens ; D.; Luo, L.; Brown, S.M.; De Boeck, M.; Chaplan, S.R.; Breitenbucher, J.G. Heteroaryl Urea Inhibitors of Fatty Acid Amide Hydrolase: Structure-Mutagenicity Relationships for Arylamine Metabolites, Bioorg. Med. Chem. Lett. 2012, 22, 7357-7362.

(52) Garamvolgyi, R.; Dobos, J.; Sipos, A.; Boros, S.; Illyes, E.; Baska, F.; Kekesi, L.; Szabadkai, I.; Szantai-Kis, C.; Keri, G.; Orfi, L. Design and Synthesis of New Imidazo[1,2-a $]$ pyridine and Imidazo [1,2-a]pyrazine Derivatives with Antiproliferative Activity Against Melanoma Cells, Eur.J. Med. Chem. 2016 $108,623-643$.

(53) Chao, H.; Li, L.; Chunshen, Z. Preparation Process of 8-Iodo-6Nitroimidazo[1,2-a]pyridine, CN107129496, 2017.

(54) Dwyer, M.P.; Paruch, K.; Alvarez, C.; Doll, R.J.; Keertikar, K.; Duca, J.; Fischmann, T.O.; Hruza, A.; Madison, V.; Lees, E.; Parry, D.; Seghezzi, W.; Sgambellone, N.; Shanahan, F.; Wiswell, D.; Guzi, T.J. Versatile Templates for the Development of Novel Kinase Inhibitors: Discovery of Novel CDK Inhibitors, Bioorg. Med. Chem. Lett. 2007, 17, 6216-6219.

(55) Huang, W.S.; Metcalf, C.A.; Sundaramoorthi, R.; Wang, Y.; Zou, D.; Thomas, R.M.; Zhu, X.; Cai, L.; Wen, D.; Liu, S.; Romero, J.; Qi, J.; Chen, I.; Banda, G.; Lentini, S.P.; Das, S.; Xu, Q.; Keats, J.; Wang, F.; Wardwell, S.; Ning, Y.; Snodgrass, J.T.; Broudy, M.I.; Russian, K.; Zhou, T.; Commodore, L.; Narasimhan, N.I.; Mohemmad, Q.K.; Iuliucci, J.; Rivera, V.M.; Dalgarno, D.C.; Sawyer, T.K.; Clackson, T.; Shakespeare, W.C. Discovery of 3-[2-(Imidazo[1,2-b]pyridazin-3-yl)ethynyl]-4-methyl-N-\{4-[(4-methylpiperazin-1yl)methyl]-3-(trifluoromethyl)phenyl\}benzamide (AP24534), a Potent, Orally Active Pan-inhibitor of Breakpoint Cluster Region-abelson (BCR-ABL) Kinase Including the T315I Gatekeeper Mutant, J. Med. Chem. 2010, 53, 4701-4719.

(56) Desroy, N.; Housseman, C.; Bock, X.; Joncour, A.; Bienvenu, N.; Cherel, L.; Labeguere, V.; Rondet, E.; Peixot, C.; Grassot, J.M.; Picolet, O.; Annoot, D.; Triballeau, N.; Monjardet, A.; Wakselman, E.; Roncoroni, V.; Le Tallec, S.; Blanque, R.; Cottereaux, C.; Vandervoort, N.; Christophe, T.; Mollat, P.; lamers, M.; Auberval, M.; Hrvacis, B.; Ralic, J.; Oste, L.; Van Der Aar, E.; Brys, R.; Heckmann, B. Discovery of 2-[[2-Ethyl-6-[4-[2-(3-hydroxyazetidin-1-yl)2-oxoethyl]piperazin-1-yl]-8-methylimidazo[1,2-a]pyridin-3-yl]methylmino]-4-(4-fluorophenyl)thiazole-5-carbonitrile (GLPG1690), a First-inClass Autotaxin Inhibitor Undergoing Clinical Evaluation for the Treatment of Idiopathic Pulmonary Fibrosis, J. Med. Chem. 2017, 60, 3580-3590 (57) Molander, G. A. ; Cadoret F. Synthesis of the Stereogenic Triad of the Halicyclamine A Core, Tetrahedron Lett. 2011, 52, 2199-2202.

(58) Casimiro-Garcia, A.; Bigge, C.F.; Davis, J.A.; Padalino, T.; Pulaski, J.; Ohren, J.F.; McConnell, P.; Kane, C.D. ; Royer, L.J.; Stevens, K.A.; Auerbach, B.J. ; Collard, W.T.; McGregor, C.; Fakhoury, S.A.; Schaum, R.P.; Zhou, H. Effects of Modifications of the Linker in a Series of Phenylpropanoic Acid Derivatives: Synthesis, Evaluation as $\mathrm{PPARa} / \mathrm{c}$ Dual Agonists, and X-ray
Crystallographic Studies, Bioorg. Med. Chem. 2008, 16, 4883-4907.

(59) Wang, Y.D. ; Kimball, G. ; Prashad, A.M. ; Wang, Y. Zr-Mediated Hydroboration: Stereoselective Synthesis of Vinyl Boronic Esters, Tetrahedron Lett. 2005, 46, 8777-8780.

(60) Loubidi, M.; Jouha, J.; Tber, Z.; Khouili, M.; Suzenet, F.; Akssira, M.; Erdogan, M.A.; Kose, F.A.; Dagci, T.; Armagan, G.; Saso, L.; Guillaumet, G. Efficient Synthesis and First Regioselective C-6 Direct Arylation of Imidazo[2,1c] $[1,2,4]$ triazine Scaffold and their Evaluation in $\mathrm{H}_{2} \mathrm{O}_{2}$-Induced Oxidative Stress, Eur. J. Med. Chem. 2018, 145, 113-123.

(61) Marchand, P.; Bazin, M.A.; Pagniez, F.; Riviere, G.; Bodero, L.; Marhadour, S.; Nourrisson, M.R.; Picot, C.; Ruchaud, S.; Bach, S.; Barratte, B.; Sauvain, M.; Castillo Pareja, D.; Vaisberg, A.J.; Le Pape, P. Synthesis, Antileishmanial Activity and Cytotoxicity of 2,3-Diaryl- and 2,3,8-Trisubstituted Imidazo[1,2-a]pyrazines, Eur.J. Med. Chem. 2015, 103, 381-395.

(62) Zidar, N.; Jakopin, Z.; Madge, D.J.; Chan, F.; Tytgat, J.; Peigneur, S.; Sollner Dolenc, M.; Tomasi, T.; Ilas, J.; Peterlin Masic, L.; Kikelj, D. Substituted 4-Phenyl-2-aminoimidazoles and 4-Phenyl-4,5-dihydro- 2-aminoimidazoles as Voltage-gated Sodium Channel Modulators Eur. J. Med. Chem. 2014, $74,23-30$.

(63) Bandini, M.; Bottoni, A.; Eichholzer, A.; Miscione, G.P.; Stenta, M. Asymmetric Phase-Transfer-Catalyzed Intramolecular N-Alkylation of Indoles and Pyrroles: A Combined Experimental and Theoretical Investigation Chem. Eur. J. 2010, 16, 12462-12473.

(64) Lee, H.J.; Cho, C.W. Chemoselective Suzuki Cross-Coupling Reactions of Chiral Pyrrolizines, Bull. Korean Chem. Soc. 2011, 32, 359-362.

(65) Mavel, S.; Renou, J.L.; Galtier, C.; Allouchi, H.; Snoeck, R.; Andrei, G.; De Clercq, E.; Balzarini, J.; Gueiffier, A. Influence of 2-Substituent on the Activity of Imidazo[1,2-a] Pyridine Derivatives Against Human Cytomegalovirus, Bioorg. Med. Chem. 2002, 10, 941-946.

(66) Giovanni, R.; Cui, Y.; Doods, H.; Ferrara, M.; Just, S.; Kuelzer, R.; Lingard, I.; Mazzaferro, R.; Rudolf, K. New Somatostatin Receptor Subtype 4 (SSTR4) Agonists, WO2014/184275, 2014.

(67) Bevilacqua, V.; King, M.; Chaumontet, M.; Nothisen, M.; Gabillet, S.; Buisson, D.; Puente, C.; Wagner, A.; Taran, F. Copper-Chelating Azides for Efficient Click Conjugation Reactions in Complex Media, Angew. Chem. Int. Ed. 2014, 53, 5872-5876.

(68) Assadieskandar, A.; Yu, C.; Maisonneuve, P.; Kurinov, I.; Sicheri, F.; Zhang, C.; Rigidification Dramatically Improves Inhibitor Selectivity for RAF Kinases, Med. Chem. Lett. 2019, 10, 1074-1080.

(69) Hindriksen, S.; Meppelink, A.; Lens, S. Functionality of the chromosomal passenger complex in cancer. Biochem. Soc. Trans. 2015, 43, 23-32

(70) Ting, T.-C.; Chang, M.-Y.; Hsu, T.-Y.; Wang, W.-P.; Hsieh, Y.-J.; Chang, C.-J. Vanadocene Dichloride Inhibits Cell Proliferation by Targeting Aurora B. Metallomics 2018, 10, 1099-1106.

(71) Suzuki, T.; Miyazaki, K.; Kita, K.; Ochi, T. Trivalent Dimethylarsenic Compound Induces Histone H3 Phosphorylation and Abnormal Localization of Aurora B Kinase in HepG2 Cells. Toxicol. Appl. Pharmacol. 2009, 241, $275-282$.

(72) Kaestner, P.; Stolz, A.; Bastians, H. Determinants for the Efficiency of Anticancer Drugs Targeting Either Aurora-A or Aurora-B Kinases in Human Colon Carcinoma Cells. Mol. Cancer Ther. 2009, 8, 2046-2056.

(73) Wang, F.; Ulyanova, N. P.; vann peu plus haut.; Patnaik, D.; Lens, S. M. A.; Higgins, J. M. G. A Positive Feedback Loop Involving Haspin and Aurora B Promotes CPC Accumulation at Centromeres in Mitosis. Curr. Biol. 2011, 21 , 1061-1069.

(74) McIntyre, P.J.; Collins, P.M.; Vrzal, L.; Birchall, K.; Arnold, L.H.; Mpamhanga, C.; Coombs, P.J.; Burgess, S.G.; Richards, M.W.; Winter, A.; Veverka, V.; Delft, F.V.; Merritt, A.; Bayliss, R.; Characterization of Three Druggable Hot-Spots in the Aurora-A/TPX2 Interaction Using Biochemical, Biophysical, and Fragment-Based Approaches. ACS Chem Biol. 2017, 12, 2906-2914.

(75) Zhang,; R.J.; Collins, P.M.; Foley, D.J.; Arter, C.; von Delft, F.; Bayliss, R.; Warriner, S.; Nelson, A.; Construction of a Shape-Diverse Fragment Set: Design, Synthesis and Screen against Aurora-A Kinase. Chemistry, 2019, 25, 6831-6839.

(76) Janeček, M.; Rossmann, M.; Sharma, P.; Emery, A.; Huggins, D.J.; Stockwell, S.R.; Stokes, J.E.; Tan, Y.S.; Almeida, E.G.; Hardwick, B.; Narvaez, A.J.; Hyvönen, M.; Spring, D.R.; McKenzie, G.J.; Venkitaraman, AR.; Allosteric Modulation of AURKA Kinase Activity by a Small-molecule Inhibitor of its Protein-protein Interaction with TPX2. Sci Rep. 2016, 6, 28528. DOI: $10.1038 /$ srep28528.

(77) Sessa, F.; Mapelli, M.; Ciferri, C.; Tarricone, C.; Areces, L.B.; Schneider, T.R.; Stukenberg, P.T.; Musacchio, A. Mechanism of Aurora B Activation by INCENP and Inhibition by Hesperadin. Mol Cell. 2005, 18, 379-391. 
(78) Xu, Z, Ogawa, H, Vagnarelli, P, Bergmann, JH, Hudson, DF, Ruchaud, S, Fukagawa, T, Earnshaw, WC, Samejima, K. INCENP-aurora B Interactions Modulate Kinase Activity and Chromosome Passenger Complex localization. J. Cell. Biol. 2009, 187, 637-653. Erratum in: J. Cell. Biol. 2010, 188, 611.

(79) Martinez R.; Defnet A.; Shapiro P. Avoiding or Co-Opting ATP Inhibition: Overview of Type III, IV, V, and VI Kinase Inhibitors. In: Shapiro P. (ed.) Next Generation Kinase Inhibitors, Springer, Cham, Switzerland, 2020, 29-59. doi: 10.1007/978-3-030-48283-1_3.

(80) Lakkaniga N. R.; Zhang L.; Belachav B.; Gunaganti N.; Frett B.; Li H. Discovery of SP-96, The First non-ATP-competitive Aurora Kinase B Inhibitor, for Reduced Myelosuppression. Eur.J. Med. Chem. 2020, 203, 1-11.
(81) Elkins, J.M.; Santaguida, S.; Musacchio, A.; Knapp, S. Crystal Structure of Human Aurora B in Complex with INCENP and VX-680. J. Med. Chem. 2012, 55, 7841-7848.

(82) « Zegzouti, H.; Zdanovskaia, M.; Hsiao, K.; Goueli, S.A.; ADP-Glo: A Bioluminescent and Homogeneous ADP Monitoring Assay for Kinases, Assay Drug Dev Technol. 7, 2009, 560-572.

(83) Verdonk, M.L.; Cole, J.C.; Hartshorn, M.J.; Murray, C.W.; Taylor, R.D. Improved protein-ligand docking using GOLD. Proteins 2003, 52, 609-623.

(84) Pettersen, E.F.; Goddard, T.D.; Huang, C.C.; Couch, G.S.; Greenblatt, D.M.; Meng, E.C.; Ferrin, T.E. UCSF Chimera-a Visualization System for Exploratory Research and Analysis. J. Comput. Chem. 2004, 25, 1605-1612. 